William \& Mary Law School

William \& Mary Law School Scholarship Repository

$11-2020$

\title{
Framing the Second Amendment: Gun Rights, Civil Rights and Civil Liberties
}

Timothy Zick

William \& Mary Law School, tzick@wm.edu

Follow this and additional works at: https://scholarship.law.wm.edu/facpubs

Part of the Constitutional Law Commons, and the Second Amendment Commons

\section{Repository Citation}

Zick, Timothy, "Framing the Second Amendment: Gun Rights, Civil Rights and Civil Liberties" (2020).

Faculty Publications. 2029.

https://scholarship.law.wm.edu/facpubs/2029

Copyright c 2020 by the authors. This article is brought to you by the William \& Mary Law School Scholarship Repository.

https://scholarship.law.wm.edu/facpubs 


\title{
Framing the Second Amendment: Gun Rights, Civil Rights and Civil Liberties
}

\author{
Timothy Zick
}

\begin{abstract}
Gun rights proponents and gun control advocates have devoted significant energy to framing the constitutional right to keep and bear arms. In constitutional discourse, advocates and commentators have referred to the Second Amendment as a "collective," "civic republican," "individual," and "fundamental" right. Gun rights advocates have defended the right to keep and bear arms on "law and order" grounds, while gun control proponents have urged regulation based on "public health," "human rights," and other concerns. These frames and concepts have significantly influenced how the right to keep and bear arms has been debated, interpreted, and enforced. This Article focuses on two common frames gun rights advocates have used to construct realities, identify grievances, motivate supporters, and ultimately influence the meaning of the Second Amendment. Advocates have framed the right to keep and bear arms as a "civil right" primarily concerned with equality values and opposed to discriminatory treatment of gun owners and gun rights. Gun rights advocates have also developed and deployed a "civil liberty" frame that warns of impending disarmament, loss of liberty, and tyrannical government. Framing the Second Amendment in these discrimination and disarmament terms has deeply affected gun rights discourse, lawmaking, and judicial decisions. The Article focuses on the vocabulary of arms in order to better understand how advocates in gun debates generate and use frames, and how those frames affect the Second Amendment's meaning. Constitutional framing by both gun rights and gun control advocates will significantly influence future debates about the meaning and scope of the Second Amendment.
\end{abstract}

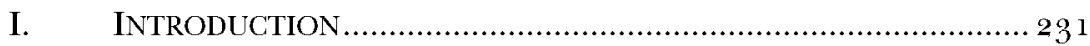

II. DEMOCRATIC LAWMAKING AND CONSTITUTIONAL FRAMING...... 296

John Marshall Professor of Government and Citizenship, William \& Mary Law School. I would like to thank Joseph Blocher, Darrell Miller, and the other participants at the Duke Center for Firearms Law works-in-progress conference for their helpful comments. I would also like to thank my research assistant, Chantaya Costa. 
A. Constituthonal Culture and Constitutional

MEANING.

B. CONSTITUTIONAL FRAMES................................................. 239

III. THE SECOND AMENDMENT's CIVIL RIGHTS FRAME........................ 242

A. RACE, "CIVIL RIGITTS," AND FIREARMS - EARLY

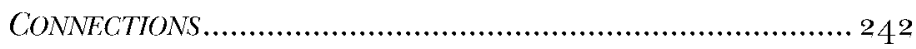

B. ARMS AND EQUALITY - TIIE MODERN CIVII RIGITTS

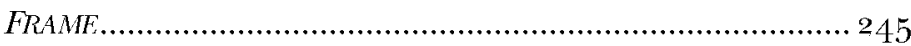

1. Givil Rights, Gun Rights, and the "Law and

Order" Frame ............................................................. 245

2. Gun Control's "Ugly History"..................................... 248

3. "Gun Control is Racist"............................................. $25^{2}$

4. Firearms and the Civil Rights Movement..................... 255

C. CIVIL RIGHTS COUNTIR-FRAMES ......................................... $25^{8}$

D. TIIE CIIL RIGIITS AGENDA......................................................... 260

E. CIVIL RIGIITS RIETORIC VERSUS REALITY................................262

1. Discrimination and Gun Control ................................ 262

2. Arms and Civil Rights ........................................... 264

3. Gun Rights as Equality Rights ................................... 267

IV. The SECONd AMENDMENT's Civil Liberties Frame................... 272

A. THE NATURE OF "CIVII. LIBLRTY"....................................... 272

B. CONTIMPORARY CIVIL LIBLRTILS FRAMIS............................... 275

1. The Libertarian Second Amendment.......................... 275

2. Disarmament, Despotism, and Absolutism ................. 276

3. The "Freedom Lovers" Narrative ……………............... 280

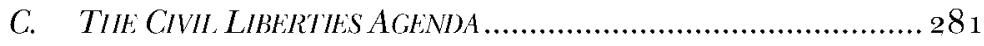

D. CIVIL LIBERTIES RHETORIC VERSUS REALITY ........................... 284

1. "Liberty" Versus "License" ........................................ 284

2. The Second Amendment's Imminent

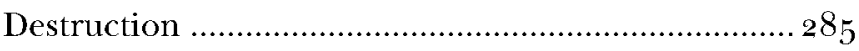

3. "Second-Class" Claims .......................................... 286

V. FRAMING EFFECTS: DISCOURSE, DOCTRINE, AND THEORY …........ 287

A. TIIE POWER AND PersistenCE OF SECOND AMENDMENT

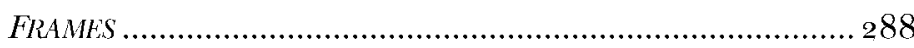

B. SECOND AMENDMENT DISCOURSE-OVERIIEATING AND

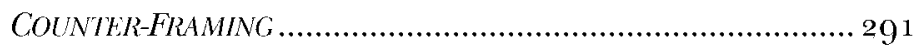

C. SECOND AMENDMENT DOCTRINE AND GUN LAWS..................... 294

D. FRAMING SECOND AMENDMFNT JUSTIFICATTONS ...................... 295

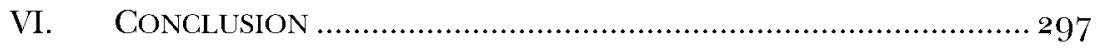




\section{INTRODUCTION}

Constitutional rights are important forms of power and rhetoric.' How we characterize, describe or label a constitutional right significantly affects interpretation, enforcement, and public support. ${ }^{2}$ These things also affect the tenor and quality of public policy debates about the right. ${ }^{3}$ As America struggles through intermittent waves of gun violence, 1 it is important that we consider how advocates, scholars, officials, and the people have characterized and argued about the Second Amendment. Public contests over meaning are important to a nation's civic traditions and can significantly influence interpretation of constitutional rights. 5 With regard to the Second Amendment, how activists and advocates have framed the right to keep and bear arms has significantly affected gun laws and judicial decisions.

It has now been just over a decade since the Supreme Court recognized an individual right to keep and bear arms in District of Columbia v. Heller. ${ }^{6}$ That decision was the culmination of decades of scholarship, advocacy, and litigation framing the Second Amendment as a "law and order" provision closely linked to personal self-defense and rejecting "civic republican" conceptions that connected arms to organized militias. ${ }^{7}$

As scholars have shown, constitutional interpretation is a product of a collective process that includes formal lawmaking, adjudication, and public discourse. ${ }^{8}$ A critical part of this democratic process involves the "framing" of

1. See Jack M. Balkin, Digilal Speech and Democralic Cullure: $\Lambda$ Theory of Lreedom of Expression for the Informalion Society, 79 N.Y.U. L. REv. 1, 4 (2004).

2. Other scholars have recently turned to studies of language and metaphor to understand the substance of constitutional rights. See, e.g., Marie-Amélie George, Framing Trans Rights, 114 Nw. U. L. Riv. 555, 576, 580-81, 691 (2019); Dov Fox, Thitteenth Amendment Reflections on Abortion, Surrogacy, and Race Selection, 104 CORNELl L. Rev. ONLINE $114,115^{-16}, 13^{6}$ (2019) (considering slavery frames in the context of reproductive rights).

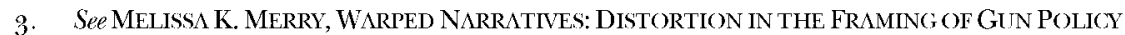
$3(2020)$.

4. See Eugenio Weigend Vargas, Gun Violence in America: $A$ State-by-State Analysis, CIR. For AM. PRoGriss (Nov. 20, 2019, 9:05 AM), https://www.americanprogress.org/issues/gunscrime/news/2019/11/20/477218/gun-violence-america-state-state-analysis [https://perma.cc/ $\left.\mathrm{MQ3U}-\mathrm{TQ}_{5} \mathrm{~B}\right]$ (collecting gun violence data).

5. See Reva B. Siegel, Dead or Alive: Originalism as Popnlar Comstitutionalism in Heller, 122 Harv. L. Rliv. 191, 239 (2008) [hereinafter Siegel, Dead or Alive] ("Twentieth-century conflict helped tutor intuitions about the Second Amendment's core and periphery.").

6. District of Columbia v. Heller, 554 U.S. $57 \%, 592$ (2008).

7. Id. at 628 (" $[\mathrm{T}]$ he inherent right of self-defense has been central to the Second Amendment right."); Siegel, Dead or Alive, supra note 5, at 239; see also SAul CoRnlil. I., A Wlil. I-

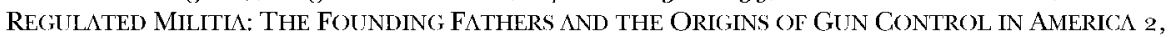
$18-24,214$ (2006) (framing the Second Amendment as a "civic" right, a civic republican term that centers on individual rights to keep and bear arms for the purpose of state militia service).

8. See Robert Post \& Reva Siegel, Roc Rage: Democratic Constitutionalism and Backlash, 42 HARV. C.R.-C.L. L. REv. 373, 373-74 (2007) [hereinafter Post \& Siegel, Roe Rage]; Reva B. Siegel, Constitulional Cullure, Social Movement Conflict and Comsilutional Change: The Case of the De lacto LRA, 94 CAI.IF. L. Riv. 1323, 1324-25 (2006) [hereinafter Siegel, Consilutional Cullure]; Jack M. 
constitutional rights.9 Frames construct realities, sharpen grievances, and motivate participants in constitutional movements. ${ }^{10}$ Constitutional frames provide a vocabulary for organizing and communicating ideas and beliefs about constitutional rights. ${ }^{11}$ "They are instruments, rallying cries, [and] tools of persuasion." 12 "[L]aw and order," individual self-defense, and other narratives were critical to the Supreme Court's eventual recognition of an individual Second Amendment right. ${ }^{13}$

Contests over constitutional meaning are dynamic and evolutionary. Heller is merely one chapter in the story of how advocates and others have narrated, characterized, and framed the right to keep and bear arms in public discourse and lawmaking. Prior to Heller, advocates framed the right in libertarian and collective registers. ${ }^{4}$ Since Heller, pitched battles have played out in courts and public commentary over whether courts are properly treating the Second Amendment as a "fundamental" right, or whether they have instead relegated it to "second-class" status. ${ }^{15}$

Both prior to and after Heller, gun rights advocates have framed the Second Amendment as a "civil right" and a "civil liberty." ${ }_{16}$ These Second Amendment frames have been around for decades, but scholars have not critically analyzed them. This Article focuses on this particular aspect of Second Amendment discourse and interpretation. It provides the first careful assessment of the Second Amendment's civil rights and civil liberties frames or narratives.

Although they have long histories and variable meanings, since the middle of the twentieth century, common usage has treated "civil rights" as protections from unequal treatment based on protected characteristics or

Balkin \& Reva B. Siegel, Principles, Practices, and Social Movements, 154 U. PA. L. Riv. 927, 928 (2006) [hereinafter, Balkin \& Siegel, Principles]; Reva B. Siegel, Equality Talk: Antisubordination and Anticlassification Values in Constitutional Struggles Over Brown, 117 HARV. L. REV. $147^{\circ}, 1474$ -75 (2004) [hereinafter Siegel, Equality Talk]; Robert Post \& Reva Siegel, Popular Constitutionalism, Departmentalism, and fudicial Supremacy, 92 CAIIF. L. Rlv. 1027,1029 (2004) [hereinafter Post \& Siegel, Popular Comstitutionalism].

9. For a review of the literature on framing as it relates to social movements, see generally Robert D. Benford \& David A. Snow, Framing Processes and Social Movements: An Overviez and Assessment, 26 ANN. REV. SOCIO. 611 (2000).

10. Id. at $63^{\circ}-3^{2}$.

11. See sources cited supra note 8.

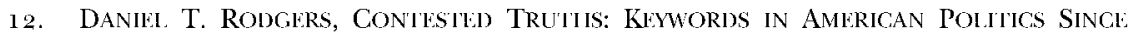
INDEPLNDENCL $10(1987)$.

13. See Siegel, Dead or Alive, supra note 5, at 193-94 (connecting Heller's interpretation of the Second Amendment "to the decades of social movement conflict that preceded the decision").

14. See generally CORNELL, supra note 7 (examining support for collective right interpretation).

15. See generally Timothy Zick, The Second Amendment as a Fundamental Right, ${ }_{4}^{6}$ HusTiNGS CONST. L.Q. 621 (2019) (examining the senses in which the Second Amendment is and has been treated by courts as a "fundamental" right).

16. See infra Parts III-IV. 
traits, such as race, sex, or sexual orientation. "Civil liberties" has generally referred to individual rights implicitly or explicitly guaranteed by the Constitution. ${ }^{17}$ These conceptual frames do not have legal force. However, as others have noted, they substantially affect the meaning and enforcement of constitutional rights. ${ }^{18}$ The distinction between them "provides a language by which to oppose, to praise, and to reconcile many of our era's legal issues" -including those related to the Second Amendment. ${ }^{19}$

Using these concepts, gun rights advocates have developed and deployed both civil right discrimination and civil liberty disarmament frames. ${ }^{20}$ Advocates have rooted the discrimination frame in concerns about equality that invoke the complicated historical relationship between race and arms. ${ }^{21}$ According to this constitutional frame, gun rights have always been, and continue to be, connected to equality rights-particularly concerns about racial equality. ${ }^{22}$ This frame originated in pre-Heller scholarship examining the historical relationship between arms and race. ${ }^{23}$ It began to appear more frequently after the Supreme Court issued its decision in McDonald \%. City of Chicago,

17. See Christopher W. Schmidt, The Civil Rights-Civil Liberties Divide, 12 STAN. J.C.R. \& C.L. 1, 4 (2016); see also Civil Liberty, Bi ACK's LAW DiCIIONARY (7th ed. 1999); Jack Greenberg, Civil Rights, in ENCYCIOPIDIA OF TIIL: AMIRICAN CONSITUUTION 273, 273-81 (Leonard W. Levy \& Kenneth L. Karst eds., gd ed. 2000); John E. Semonche, Civil Righls and Civil Liberties, in THE OXford COMPANION 'TO AmlikiCAN LAW 110 (Kermit L. Hall ed., 2002); Thomas C. Grey, Civil Rights us. Civil Liberties: The Case of Discriminatory Verbal Ilarassment, 63 J. HIGI It:R Eou $C_{4} 485,486$ (1992).

18. See Schmidt, supra note 17 , at 5 (citing, for example, debates over hate speech regulation and the framing of claims in the gay rights movement).

19. Id. at $4^{\mathrm{o}}$.

20. See infra Parts III-IV.

21. See infra Part III.

22. See, e.g., ChuRLes E. CoBb JR., This Nonviolent STUFF'Ll Get You KILlED: How GUNS Made THe Crvil Rights Movement Possible 81-82 (2014); Damon Root, How the Second Amendment Helped Civil Rights Activists Resist fim Crow, RliAsON (Oct. 25, 2017, $12: 05$ PM), https:// reason.com $/ 2017 / 10 / 05 /$ how-the-second-amendment-helped-activist [https://perma.cc/ 7 TSN-gXUX]; Jarrett Stepman, Gun Rights Actually Are a Civil Rights Issue, DAILY SIGNAL (Mar. 28, 2018), https://www.dailysignal.com/2018/09/28/gun-rights-are-a-civil-rights-issue [https:// perma.cc/4Q8E-4 $\mathrm{YQ}_{9}$ ] ("Gun rights and civil rights, historically, have gone hand in hand."); Norm Singleton, Rom Paul Classic: The Racist Roots of Gun Control, CAMPAIGN FOR LIBERTY (July 6, 2018) [hereinafter Singleton, Ron Panl Classic], http://www.campaignforliberty.org/ ron-paul-classic-racist-roots-gun-control [https://perma.cc/Z2VQ-EV 7 W]; Norm Singleton, Second Amendment: The Ultimate Civil Right, GAMPAIGN FOR LIBERTY (Feb. 27, 2019) [hereinafter Singleton, Second Amendment], http://www.campaignforliberty.org/second-amendment-ultimate -civil-right-2 [https://perma.cc/FgXE-QKGV].

23. See Robert J. Cottrol \& Raymond T. Diamond, The Second Amendmenl: Toulard an AfroAmericanist Reconsideration, 8 o Gro. L.J. 309, 396-38 (1991) [hereinafter Cottrol \& Diamond, The Second Amendment]; Robert J. Cottrol \& Raymond T. Diamond, "Never Intended to Be Applied to the White Population": Firearms Regulation and Racial Disparity-The Redeemed South's Legacy to a National hurisprudence?, 70 Ci II.-KleNT L. Rlv. 1307, 1907-08 (1995) [hereinafter Cottrol \& Diamond, Never Inlended]. 
which referenced some of the historical evidence relating to race and gun control as it applied the Second Amendment to the states. 24

In its modern and most aggressive forms, the civil rights frame invokes the "ugly history" of gun control, argues "all gun control is racist," analogizes gun control laws to poll taxes and literacy tests, accuses lower courts of "massive resistance" to enforcement of gun rights, and complains that the Second Amendment has been relegated to "the back of the constitutional bus." ${ }_{25}$ Further, in connection with debates about the "fundamental" nature of the Second Amendment right, gun rights proponents have repeatedly claimed that courts are treating Second Amendment claims and gun owners as "second class." ${ }^{26}$ Some gun rights advocates have even sought to co-opt the vocabulary of contemporary civil rights activists by, among other things, adopting labels such as "Black Guns Matter" and "Gun Rights Matter." ${ }_{7}$

The civil liberty "disarmament" frame focuses on autonomy and antityranny values, with the central concern being confiscation of arms from lawabiding citizens. ${ }^{28}$ The modern civil liberties frame appears to have originated in the speeches, publications, and marketing materials distributed by the National Rifle Association ("NRA") during the 1970s. ${ }^{29}$ At that time, the NRA adopted the libertarian framing of the Second Amendment and began to deploy it politically and in courts. $3^{\circ}$

In its modern version, gun rights advocates have used the civil liberties frame to warn that a "Disarm America Movement" led by tyrannical governments and progressive politicians seeks to confiscate the firearms and weapons of all law-abiding Americans. ${ }^{31}$ The disarmament frame presents gun rights advocates as lovers of freedom and defenders of liberty and casts their opponents as liberty-haters..$^{2}$ According to this narrative, the Second Amendment is the liberty that preserves all others (America's "First

\footnotetext{
24. McDonald v. City of Chicago, $5^{61}$ U.S. 742,779 (2010).

25. See infra Part III.

26. See generally Zick, supra note ${ }_{5} 5$ (analyzing "second class" claims made in legal filings and other sources).

27. See, e.g., Gun Rights Matter, FaCliBOOK, https://www.facebook.com/GunRightsMatter [https://perma.cc/UY65-5 ${ }_{5}^{\mathrm{PKW}}$.

28. See infra Part IV.

29. See Siegel, Dead or Alive, supra note 5 , at $228-93$ (describing the shift toward populist and libertarian framing of the Second Amendment); id. at 214 (describing direct mail materials); see also id. at $208 \mathrm{n} .75$ (contending that public support for gun control was waning).

3o. See id. at $208-09$.

31. E.g., Oliver L. North, President's Column: Giving the Gift of Freedom, NRA (Nov. 23, 2018), https://www.americas stfreedom.org/articles/2018/11/23/president-s-column-giving-the-giftoffreedom [https://perma.cc/5JVX-YgVZ].

32. See David Smith, NRA Ilead Breaks Silence to Attack Gun Control Advocates: 'They IIate Individual Freedom,' GuARDIAN (Feb. 22, 2018, 1:10 PM), https://www.theguardian.com/us -news $/ 2018 / \mathrm{feb} / 22 /$ nra-wayne-lapierre-gun-control-cpac-speech-2018 [https://perma.cc/ UEJ9-8RYH].
} 
Freedom"). .33 As such, it cannot be subject to public safety or other traditional limits imposed on the exercise of civil liberties. Thus, the disarmament frame presents the Second Amendment as an absolute and "ironclad" right.

This Article focuses on the substance, strategy, and implications of these two legal frames. It pays special attention to the terms and vocabularies deployed, particularly in contemporary discourse about the Second Amendment. Second Amendment civil rights and civil liberties frames are powerful forms of political rhetoric. Second Amendment narratives are also associated with particular constitutional and legal agendas. These include changes to constitutional doctrines, the application of heightened levels of judicial scrutiny, enactment of affirmative protections for gun owners, and increased public and political support for gun rights. Although advocates have taken considerable liberties in constructing the discrimination and disarmament narratives, both frames have been quite effective.

As two leading Second Amendment scholars recently observed, "[w]e are witnessing, in real time, the formation of a constitutional right." 31 How advocates have framed the Second Amendment and the narratives they use in the future to debate and interpret it will significantly affect its future meaning and scope. The Supreme Court is poised to embark on this project, which will likely span many decades. 35 During this time, the framing of the right to keep and bear arms will continue to influence the Court's work and that of other lawmaking institutions. $3^{6}$

Part II of the Article briefly situates the analysis of Second Amendment framing in existing literature concerning "constitutional culture," "democratic constitutionalism," and "framing." "37 This introduction explains the relationship between framing and the interpretation of constitutional rights by courts, legislatures, and the people.

Part III examines the development and deployment of the civil rights frame, and Part IV explores the Second Amendment's civil liberties frame. These discussions trace the evolution of each frame in Second Amendment discourse. They provide an overview of the character and content of the frames and explain how groups and individuals have deployed them in gun rights discourse. Parts III and IV describe the constitutional and legal agendas

33. Jonathan Lowy \& Kelly Sampson, The Right Not to Be Shot: Public Safety, Private Guns, and the Constellation of Constitutional Liberties, 14 GEO. J.L. \& PUB. POL'Y 187, 189 \& n.9 (2016) (noting that this is the title of a popular NRA magazine).

34. Joseph Blocher \& Darrell A. H. Miller, The Positive Second Amendment: Rights, REGULATION, AND THE FUTURE OF IIELLLR 99 (2018).

35. The Court initially granted certiorari in New York Stale Rifle E Pistol Ass'n Inc. v. Caly of Now York, 883 F.3d 45 (2d Cir. 2018), only to dismiss the case as moot. N.Y. State Rifle \& Pistol Ass'n Inc. v. City of New York, 140 S. Ct. $1525,15^{26}$ (2020).

36. See Siegel, Constitutional Culture, supra note 8 , at 1323 (describing the process by which "constitutional culture channels social movement conflict to produce enforceable constitutional understandings").

37. See sources cited supra note 8. 
associated with each frame and critically assess framing rhetoric as it relates to current political and constitutional realities.

Part V draws some lessons and implications from the Second Amendment's constitutional framing. As the two frames show, narratives are powerful forms of constitutional rhetoric. They are useful both collectively, in social movements, and as individual vocabularies. In their most aggressive forms, the discrimination and disarmament narratives lack credibility-in the sense that the problems they purport to address are overstated or even nonexistent. $3^{8}$ Nevertheless, the frames have persisted and even thrived.39 This has contributed to a dysfunctional discourse about gun rights and gun control. $4^{\circ}$ Rather than create common ground and civic attachment, Second Amendment framing has so far largely contributed to civic strife concerning guns. ${ }^{41}$ Further, particularly since Heller, firearms framing has been mostly one-sided, which is to say gun control advocates have not developed any effective counter-frames. $1^{2}$ An effective gun control counter-movement has yet to materialize.13 This is a worrisome deficiency. Framing will significantly influence the development of the Second Amendment's future meanings, doctrines, and justifications. Gun control advocates concerned about these matters will need to develop and deploy effective counter-frames.

\section{DEMOGRATIC LAWMAKING AND CONSTITUTIONAL FRAMING}

This Article examines the distinctive constitutional vocabulary of the Second Amendment. The study relies on the literature concerning "constitutional culture," "democratic constitutionalism," and "framing." 44 These concepts relate to the processes in which advocates, litigants, courts, and the people debate and influence the meaning of the Constitution. After briefly situating the current study in the relevant literature, the Article addresses the Second Amendment's "civil rights" and "civil liberties" frames.

38. See Benford \& Snow, supra note 9, at 616-17 (discussing solution-based and motivational functions of social movement frames).

39. See id. at 619 (discussing conditions under which frames resonate with movement participants).

40. See Joseph Blocher, Gun Rights Talk, 94 B.U. L. Riv. 813, 814 (2014); Donald Braman \& Dan M. Kahan, Overcoming the Fear of Guns, the Fear of Gun Control, and the Fear of Cultural Politics: Constmucting a Better Gun Debate, 55 Emoky L.J. 569,569 (2006); Dan M. Kahan, The Gun Control Debate: A Culture-Theory Manifesto, 6o WASH. \& LEE L. REV. 3 , 3 (2003).

41. See Siegel, Constitutional Culture, supra note 8, at 1419 (explaining that democratic discourse about constitutional rights rests on shared traditions, is generally accommodating, and leads to normatively desirable forms of "civic attachment"); Siegel, Equality Talk, supra note 8, at 1498 (discussing how "anti-classification" discourse had "the virtue of cooling debate" concerning Browm and segregation).

42. See Post \& Siegel, Roe Rage, supra note 8, at 377 (arguing that progressives debating constitutional rights "need substantive constitutional ideals").

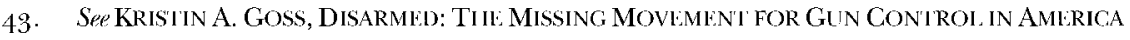
$3(2006)$.

44. See generally sources cited supra note 8. 


\section{A. Constitutional Culture and Constitutional Meaning}

As Reva Siegel has defined it, "constitutional culture ... refer[s] to the understandings of role and practices of argument that guide interactions among citizens and officials in matters concerning the Constitution's meaning." 1.5 By providing shared norms and commitments that produce constitutional change, "[c] onstitutional culture mediates the relation of law and politics." 16 It offers an alternative to the formal lawmaking framework, which focuses on constitutional change produced by things such as amendments and judicial decisions.

Constitutional culture prioritizes "popular engagement with constitutional questions" and explains how that engagement translates into constitutional change as well as "public confidence in the Constitution." 47 In this cultural context, the processes of "democratic constitutionalism" are interactive and dynamic. For example, the people interact with government officials, individually but more frequently in collective mobilizations. Officials, including lawmakers and judges, respond to arguments and translate them into formal representations of constitutional meaning. In sum, as Professor Siegel explains, constitutional culture is "a collective practice that unfolds outside the formal auspices and institutional apparatus of governance, as well as within it." ${ }^{8}$

The discourse and deliberation of democratic constitutionalism significantly affect constitutional meaning. Public discourse about the Constitution "enable[s] communication between engaged citizens and officials charged with enforcing the Constitution." 49 This exchange "helps establish what things mean and why they matter," ${ }^{\circ}$ "promote[s] forms of community identification," 51 "and infuses practical questions with symbolic significance so that they provide occasions for individuals and communities to vindicate values through which they define themselves." ${ }_{52}^{2}$ Deliberation about the Constitution draws citizens into the process of lawmaking, which thereby enhances the legitimacy of that process and of the Constitution. .3 According to this perspective, constitutional discourse is a public good independent of constitutional lawmaking. ${ }^{51}$ Getting people to talk about the

\footnotetext{
45. Siegel, Constitutional Culture, supra note 8 , at 1325 .

46. Id. at 1327 .

47. Id. at $134^{\circ}$.

48. Id. at $135^{2}$.

49. Id. at $134^{2}$.

5 o. Id. at 1941 .

51. Id. at 1943 .

52 . Id. at 1341 .

53. See id. at 1340 (observing that interactions between public and officials "contribute to the public's confidence in the Constitution's democratic authority").

54. Id. at $134^{1 .}$
} 
Constitution's meaning binds them together in a common endeavor and forges "civic attachment."

In operation, constitutional culture is a "practice of argument" or "set of constraints on argument that guide the ways advocates make claims of constitutional meaning. $" 5^{6}$ Partisans express their aspirations and claims in constitutional idioms or registers, "in the language of public value." 57 They do so according to two conditions, which Siegel refers to as "consent" and "public value," which tame and legitimize constitutional arguments. The "consent condition" requires that advocates advance their constitutional visions and agendas "through persuasion, by appeal to the Constitution." ${ }^{8}$ The mode of address is critical, as the consent constraint helps form a constitutional community based on shared convictions. Siegel argues " $[\mathrm{t}]$ he public value condition requires" social movement participants and other "advocates to translate partial and partisan judgments about constitutional meaning into the language of a common tradition." 59 Like consent, public value constrains the manner in which advocates seek to persuade others to adopt their interpretation of the Constitution by limiting the forms of appeal they can make. Only by advancing this sort of shared tradition can advocates legitimately transform constitutional meaning.

Democratic constitutionalism relies on these persuasive and deliberative processes as a means of legitimizing constitutional change. io $^{\text {Popular }}$ engagement authorizes citizens to make claims about constitutional meaning, to make claims for constitutional change, and to oppose government when it fails to respond to their appeals.

"Courts play a special role in this process" because "[they] exercise a distinctive form of authority to declare and enforce rights." 61 When courts fail to respond to their arguments, advocates communicate objections to judicial decisions. ${ }^{62}$ Thus, judicial decision-making is part of constitutional culture and democratic constitutionalism, but we ought not to confuse court decisions with the Constitution. Rather, constitutional meaning is the product of the diverse and dynamic interactions between and among citizens, political and cultural institutions, and courts. ${ }^{63}$ 
Constitutional culture and democratic constitutionalism are useful models that explain the construction of constitutional meaning as a product of discourse, persuasion, and public advocacy. As theorists have generally described it, democratic constitutionalism depends in particular on the collective activities of social movements and counter-mobilizations. ${ }^{b_{1}}$ However, the concepts of constitutional culture and democratic constitutionalism do not rule out individual engagements with constitutional meaning. To participate in collective advocacy, individuals first need to make sense of the Constitution and practice framing constitutional arguments. They also debate constitutional meaning in a variety of fora, some of which are and some of which are not part of organized or collective activities. In sum, we can think of democratic constitutionalism as both a team and individual sport.

\section{B. CONSTTUUTIONAL FRAMLS}

In order to understand how discourse motivates and mobilizes audiences and affects constitutional interpretation, scholars have looked to the social science concept of "framing." $6_{5}$ They have paid special attention to the "collective action frames" organizations have relied upon to motivate and persuade individuals. ${ }^{66}$

For example, Professor Siegel has studied the development of a "womanprotective" frame or narrative used by anti-abortion advocates to influence recent debates and judicial decisions concerning the constitutional right to abortion. ${ }^{67}$ As discussed further in Part III, Siegel has also shown that framing helps explain the Supreme Court's eventual recognition of an individual right to keep and bear arms in Heller. ${ }^{68}$

This Article uses the framing concept to understand how Second Amendment "civil rights" and "civil liberties" narratives have been developed and deployed in democratic processes. Briefly, frames are schemas, narratives, and rationales advocates use to argue about and influence norms and meanings. ${ }^{69}$ "Collective action frames," as the literature often refers to them, serve several core functions. $7^{\circ}$ They help movement participants construct "a

\footnotetext{
64. See Balkin \& Siegel, Principles, supra note 8, at 946 ("Social movements play a key role in this process."); see also Siegel, Constitutional Culture, supra note 8, at 1923 ("Social movements change the way Americans understand the Constitution.").

65. See generally Benford \& Snow, supra note 9 (reviewing literature on framing).

66. Reva B. Siegel, The Right's Reasons: Constitutiomal Conflict and the Spread of Woman-Protective Antiabotion Argument, 57 DUKE L.J. $16_{4} 1,16_{5}^{6-57}$ (2008) [hereinafter Siegel, The Right's Reasons].

67. See id. at $165^{2-53}, 165^{6}, 1674,1681$ (discussing development of the "abortion harms women" frame used by pro-life advocates).

68. See Siegel, Dead or Alive, supra note 5, at 207-12 (discussing factors that led to the adoption of a "libertarian" interpretation of the Second Amendment).

69. See generally Benford \& Snow, supra note 9 (detailing framing processes).

7o. See id. at $613^{-1} 5$.
} 
shared understanding of some problematic condition or situation ..., make attributions regarding who or what is to blame, articulate an alternative set of arrangements, and urge others to act in concert to affect change." ${ }^{\prime 1}$ As we will see, the "civil rights" (discrimination) and "civil liberties" (disarmament) Second Amendment frames both perform these functions.

While theorists have generally focused on the collective aspects of frames and discourse, frames can also operate at more individualistic levels. Thus, a constitutional frame can be, but need not necessarily be, part of a sophisticated social movement strategy. Individuals can use frames to make sense of complex constitutional texts, principles, and values. Framing a right like the Second Amendment assists individuals with understanding and coping with constitutional complexity. In debates about constitutional rights, frames can be useful substitutes for more detailed arguments..$^{22}$ Participants can speak to one another in certain voices or registers, including constitutional ones, by relying on short hands that are accessible to both elites and non-elites.

In this sense, constitutional frames are rudimentary tools for debating constitutional ideas and expressing constitutional grievances. They can be as simple as a catchphrase, a word association, a bumper sticker, an ad campaign, or an internet meme. Thus, advocates can use arguments about "fairness" to frame the complex set of ideals that make up the Due Process Clause, or use the language of "anti-cruelty" to simplify the principles and values of the Eighth Amendment.73 As discussed later, one articulation of the "civil rights" discrimination frame in the Second Amendment context is that "all gun control is racist." Similarly, abortion opponents have deployed an "abortion harms women" argument.74 In these forms, frames help individuals process, advocate, and resist characterizations of constitutional rights. In sum, they are shorthand ways of aggregating and expressing constitutional ideas and commitments.

Advocates seek to translate those ideas and commitments into judicial interpretations and legislative protections. In this respect, the resort to constitutional frames is strategic. Both social movements and individuals deploy constitutional narratives, catch phrases, slogans, and memes to convince others, deflect arguments, and diminish objections to their claims. 75

71. Id. at $61_{5}$.

72. See, e.g., Siegel, The Right's Reasons, supra note 66 , at $165^{2-53}, 1656,1674,1681$ (discussing the "abortion harms women" frame).

73. See generally Robert L. TSA, PRACTICAL EOUALITY: Forging JUSTICE IN $\Lambda$ DIVIDED NATION (2019) (examining the rhetorical and substantive advantages of relying on non-equality frames, including anti-cruelty and rules of reason in equality discourse).

74. See Siegel, The Right's Reasons, supra note 66, at 1649 .

75. See id. (discussing the "abortion hurts women" messaging); Rob Walker, The Shifting Symbolism of the Gadsden Flag, NEW YoRKER (Oct. 2, 2016), https:/ www.newyorker.com/news/ news-desk/the-shifting-symbolism-of-the-gadsden-flag [https://perma.cc/EM2L-P5]A] (tracing meanings of the "Don't Tread on Me" slogan). See generally Dlinnis A. Henigan, "Guns Don"T 
Thus, both before and after Heller, advocates deployed law and order, civic republican, civil rights, civil liberties and other frames to influence the interpretation of the Second Amendment. $7^{6}$ They used language and narratives intentionally, to appeal to sympathetic public audiences, try to convince their opponents, and ultimately entrench these frames in laws and judicial decisions.

Constitutional frames often rely on co-opting or borrowing. 7 In seeking to characterize rights in terms of shared traditions and principles, as the consent and public value conditions discussed earlier require, advocates often borrow the language and principles of past movements. As we will see, in the case of the Second Amendment, gun rights advocates have invoked the civil rights movement in various ways to stress the equality dimension of the right to keep and bear arms..$^{7}$ Some have even tried to co-opt the terminology of current civil rights movements (e.g., "Gun Rights Matter").79

Constitutional frames change over time and are thus evolutionary. Changes in the political and constitutional cultures can affect which frames advocates deploy, how they are used, and how effective they are. ${ }^{80}$ Constitutional frames often appeal to emotion and aspects of cultural identity. ${ }^{81}$ They construct communities around particular grievances or common adversaries. ${ }^{82}$ In some contexts, the resonance of these frames may depend more on the extent to which the audience considers the frame salient or relevant than to its credibility. ${ }^{83}$ For example, although the abortion rights woman-protective frame (e.g., "abortion harms women") lacks convincing empirical support, it is nonetheless highly salient to certain audiences. ${ }^{8}$

Kill People, People Kill People": And Other Myths Abott Guns and Gun Control (2016) (examining common gun control tropes).

76. See, e.g., Siegel, Dead or Alive, supra note 5, at 214 (describing law and order framing); CORNELL, supra note 7 (examining civic republican framing of the Second Amendment).

77. See Balkin \& Siegel, Principles, supra note 8, at 941-42 (explaining how opponents of affirmative action invoked the legacy of Martin Luther King, Jr. and the civil rights movement); Siegel, The Right's Reasons, supra note 66 , at ${ }_{16} 6$ (noting that the antiabortion movement came to attack abortion rights by appropriating the language of pro-choice advocates).

78. See infra Section III.B.

79. See, e.g., Gun Rights Matter, supra note 27.

8o. See Jack M. Balkin, Iow Social Movements Change (or Fail to Change) the Constitution: The Case of the New Departure, 39 SUFFOLK U. L. REV. 27, $5^{2}$ (2005) (explaining how constitutional arguments go from "off the wall" to becoming part of constitutional common sense).

81. See Benford \& Snow, supra note 9 , at 622 (discussing the importance of cultural resonance of frames).

82. See id. at $615^{-16}$ (discussing "injustice frames" and "adversarial framing").

83. Ser id. at 619-2 1 (discussing factors that affect the resonance of frames).

84. See Siegel, The Righl's Reasons, supra note 66, at $1681-85$ (discussing empirical claims of "abortion harms women" argument). 


\section{The Second Amendment's Civil Rights Frame}

One common Second Amendment frame has sounded in civil rights and discrimination. This Part describes and critically examines the Second Amendment's civil rights framing.

\section{A. RACE, "CIVIL RIGIITS," AND FIREARMS-EARIY CONNECTIONS}

Most people probably do not think in terms of civil rights and equality when they consider gun rights. However, the historical connections between arms and equality, in particular race equality, run deep. As Professors Joseph Blocher and Darrel Miller have observed, "Gun rights and regulation have always been deeply intertwined with America's original sin, slavery, and its legacy of racial oppression." $\$_{5}$ White slave owners did not allow slaves to possess arms of any kind. State laws and "slave patrols"-which were sometimes militias or individuals loosely associated with militias-ensured that slaves were disarmed. ${ }^{86}$

This situation generally persisted even after emancipation. ${ }^{87}$ In Dred Scott v. Sandford, the Supreme Court ruled against a freed slave's challenge to a law denying him the rights of citizenship. ${ }^{88}$ According to the Court, to rule otherwise "would give to persons of the negro race, who were recognized as citizens in any one State of the Union, the right to enter every other State whenever they pleased . . a and to keep and carry arms wherever they went." ${ }_{9} 9$ The Court apparently considered that hypothetical state of affairs to be intolerable and dangerous to public safety.

Even after Reconstruction, African-Americans generally did not enjoy the right to keep and bear arms.9. After ratification of the Fourteenth Amendment, state laws ensured that the newly freed slave class would remain unarmed.91 The measures were not uniformly effective, and freedmen sometimes fought back. ${ }^{22}$ Some intrepid former slaves took up arms to resist the oppression of Jim Crow. 93 Modern-day gun rights advocates point to the slave and freedmen rebellions to show the deep connection between racial

\footnotetext{
85. BLOCIIER \& Millier, supra note 34 , at 35 .

86. Id. at 36 .

87. See generally STEPHEN P. HALBRoOK, FREEDMEN, THE Fol IRTEENTH AMENDMENT, AND THE RIGHT TO BEAR ARMS, 1866-1876 (1998) (detailing the history of the gun-control debate postemancipation).

88. Dred Scott v. Sandford, 6o U.S. (19 How.) $393,453-54\left(18_{5}^{6}\right.$ ).

89. Id. at $4^{16-17}$ (emphasis added).

9o. See Blocher \& MiLler, supra note 34 , at 4 o (discussing post-Reconstruction firearms restrictions).

91. Id.

92. See id. at 37 (noting that "armed groups also fought back for black protection and power").

93. See id. at $37-38$ (discussing freedmen revolts).
} 
suppression and disarmament and to emphasize the necessity of gun ownership by African-Americans and others subject to discrimination.94

To be sure, these early experiences forged a connection between racial equality concerns and the Second Amendment. As Professor Akhil Amar has observed, after Reconstruction "the poster boy of arms morphed from the Concord minuteman to the Carolina freedman."95 Ratification of the Fourteenth Amendment did not assure that African-Americans would enjoy "civil rights," including the right to keep and bear arms. $9^{6}$ As Blocher and Miller note, "achieving anything like an equal right to keep and bear arms would take generations' more work." 97

The concept of a civil right has evolved significantly over time. Before and during Reconstruction, the right to bear arms was indeed considered a "civil right"-but not in the sense that we think of such rights today. Until the middle of the twentieth century, commentators typically distinguished "civil rights" from what they termed "political rights" or "social rights." 98 This conception of civil rights included the rights to own property, make and enforce contracts, receive due process of law, and worship one's religion. 99

Thus, the federal Civil Rights Act of 1866 conferred certain "civil" rights on newly freed slaves. ${ }^{100}$ These included the right to enter contracts and own property. ${ }^{101}$ A third category of "social" rights included rights to use public accommodations and attend desegregated public schools. ${ }^{102}$ When Homer Plessy, described as an "octoroon" (a person who was one-eighth black), challenged the "separate but equal" doctrine that prevented him from riding in a "white" railway car, he was asserting a "social" right to commingle with whites and not a "civil" right (as Americans understand this sort of claim today). ${ }^{103}$

Under these early distinctions, courts and others considered the right to keep and bear arms to be a "civil" right. Thus, in United States \%. Cruikshank, the Supreme Court dismissed Cruikshank's conviction under the federal Enforcement Act of 1870 for violating the civil rights of freedmen-including,

\footnotetext{
94. See generally Cottrol \& Diamond, The Second Amendment, supra note 23 (discussing how controlling arms was used to further racial oppression).

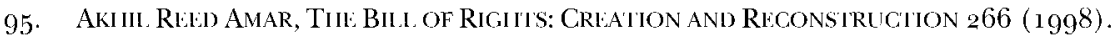

96. Blociler \& Milı. supra note 34 , at $4 \%$.

97. Id. at 41 .

98. See PAMELA Brandwein, Rethinking: the Judicial Settlement of ReCONSTRutction

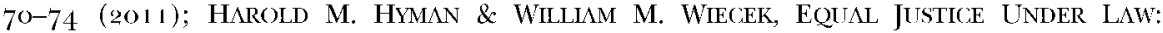
Constitutional DeVelopment, $1895^{-1875}$, at 394-97 (1982).

99. BRANDWLIN, supra note 98 , at $7 \mathbf{1}$.

100. Civil Rights Act of $1866, \mathrm{ch} .31,14$ Stat. 27.

101. Id

102. See Mark Tushnet, Civil Rights and Social Rights: The Future of the Reconstruction Amendments, 25 LOY. L.A. L. REV. 1207, 1207-1 1 (1992) (explaining Reconstruction-era distinctions among categories of rights).

103. Plessy v. Ferguson, 163 U.S. 537, 537-40 (1896).
} 
as the government alleged, their "right to keep and bear arms for a lawful purpose." $10_{4}$

Cruikshank demonstrates that eighteenth and nineteenth century Americans understood the right to keep and bear arms, whether in the context of militia service or otherwise, to be a "civil" right akin to the rights to own property or enter into contracts. ${ }^{105}$ When Congress debated and ratified the Fourteenth Amendment, they too considered the right to keep and bear arms to be a "civil right" protected by contemporaneous federal statutes (including the Givil Rights Act of 1866) and the amendment, which protected privileges and immunities and equal protection of the law. ${ }^{106}$

This early conception of "civil rights" has influenced modern judicial interpretations of the Second Amendment. In 2010, the Supreme Court invoked the Reconstruction-era concept of "civil rights" when it held that the Second Amendment was a "fundamental" right, applicable to the states. ${ }^{107}$ In McDonald $v$. City of Chicago, the Court expressly relied on the history of freedmen disarmament. ${ }^{108}$ It emphasized that Congress treated the right to keep and bear arms as a "civil right," as it then understood the term. As the Court observed, the Freedmen's Bureau Act of 1866 had provided that

the right ... to have full and equal benefit of all laws and proceedings concerning personal liberty, personal security, and the acquisition, enjoyment, and disposition of estate, real and personal, including the constitutional right to bear arms, shall be secured to and enjoyed by all the citizens ... without respect to race or color, or previous condition of slavery. ${ }^{109}$

This conception of civil rights was quite diverse. It combined elements of liberty, security, and equality. McDonald emphasized that the Civil Rights Act of 1866 protected the right to keep and bear arms as a "civil right." ${ }_{110}$ It expressly rejected arguments that early federal laws enacted to enforce the Fourteenth Amendment were concerned solely with racial discrimination. As the Court wrote, "[t] he unavoidable conclusion is that the Civil Rights Act, like the Freedmen's Bureau Act, aimed to protect 'the constitutional right to bear arms' and not simply to prohibit discrimination."112 In construing the Second Amendment, the McDonald Court foregrounded autonomy rights and

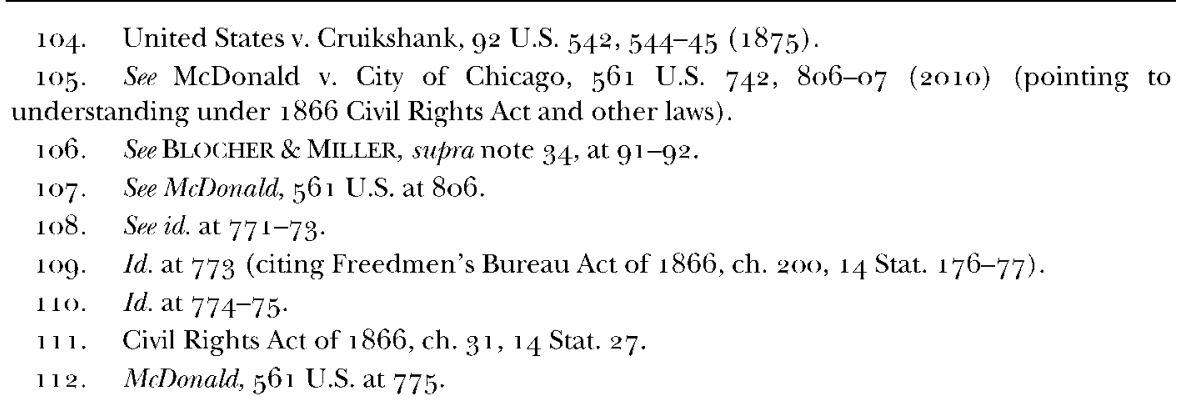


values, while generally diminishing the importance of racial equality to modern interpretations of the Second Amendment.

\section{B. ARMS AND EQUAIITY-TIIE MODERN CINIL RIGIITS FRAME}

Based on the foregoing history, it is indeed accurate to characterize the Second Amendment as a "civil right," as early Americans understood that concept. ${ }^{13}$ That, however, is not generally the civil rights frame that modern gun rights advocates deploy. The modern civil rights frame focuses more narrowly on race discrimination. ${ }^{14}$ The modern civil rights frame originated in 1960 s and 1970 s "law and order" rhetoric, which itself had racist overtones. ${ }^{15}$ Contemporary civil rights arms rhetoric seeks to elide these troublesome origins. Ignoring both the "law and order" frame and current gun ownership statistics, it argues that all modern forms of gun control are part of a longstanding plot to disarm and dominate racial and ethnic minorities. ${ }^{116}$ The modern civil rights frame combines early history, particularly the disarming of African-Americans, with an account of the civil rights movement that credits gun rights with progress on civil rights and racial equality. ${ }^{117}$ This frame presents a narrative that indelibly links race equality and gun rights as symbiotic. As we shall see, the reality of this relationship is more nuanced and complex.

1. Civil Rights, Gun Rights, and the "Law and Order" Frame

As Professor Reva Siegel has explained, " $[d]$ irectly and indirectly, conflicts over civil rights have shaped modern understandings of the Second Amendment." 118 Professor Siegel's research demonstrates that in the decades after Brown v. Board of Education, debates about Second Amendment rights relied in part on NRA and social movement concerns framed in "law and order," "self-defense," and ultimately libertarian terms. ${ }^{19}$ Those frames connect to civil rights-but in a more nuanced and complicated sense than is often represented in modern gun rights narratives.

As Professor Siegel observes, "[t]he modern quest for gun control and the gun rights movement it triggered were born in the shadow of Brown." 120

\footnotetext{
113. See Tushnet, supra note 102, at 1207.

114. See Schmidt, supra note 17 , at $1-5$ (describing civil rights as an anti-discrimination principle).

1 15. See Siegel, Dead or Alive, supra note 5, at 194 (describing development over time of the "law and order" frame).

1 16. Se Mary AnNe Franks, Tile Gult of 'TIIE CONSITIUt'ION 65-67 (2019) (discussing the white, Christian victimhood narrative relating to gun control).

117. See generally Cottrol \& Diamond, The Second Amendment, supra note 23 (discussing the convergence between firearm regulations, the Second Amendment, and the civil rights movement).

118. Siegel, Dead or Alive, supra note 5 , at 202.

119. Id. at 194, 202-12.

120. Id. at 202.
} 
"[T] he case for gun control grew in urgency ... as the nation was shaken by civil rights conflict, riots in the nation's cities, rising crime rates, campus slayings, and struggles over the Vietnam war." ${ }^{21}$ These conflicts "imbued guns with a variety of racial meanings." ${ }^{122}$ In the wake of assassinations of Martin Luther King, Jr., Medgar Evers, and President John F. Kennedy, many civil rights proponents rallied behind federal gun control proposals. ${ }^{123}$ At the time, "the NRA was prepared to support" these measures. ${ }^{121}$

For many civil rights proponents, the federal Gun Control Act of 1968 was deeply problematic because of its many war-on-crime provisions limiting the rights of criminal defendants. ${ }^{125}$ The Act foreshadowed Richard Nixon's election to office on a "law and order" platform. ${ }^{126}$ As Adam Winkler has explained, gun control regulations at both the state and federal level "represented a backlash against armed blacks who were seen to be undermining social order." 127

The "law and order" narrative generally rejected gun control as dangerous to families and society. ${ }^{128}$ By the $197 \mathrm{os}$, the NRA's rhetoric had changed dramatically, with leaders of the organization sharply differentiating between "law abiding ... gun owners" and "criminals." 129 Congress was particularly interested in disarming owners of "Saturday night specials," which "were popular in poor-read, minority-communities." $13^{\circ}$ At this point, "[t] he gun rights argument did not presume the innocence of the poor or the innocence of the accused." 191

As Adam Winkler has explained, "The new NRA-led gun rights movement was not only fueled by the laws passed to disarm the Black Panthers and other black radicals; it also echoed many of the principles espoused by the Panthers." $13^{2}$ However, as the law and order frame developed, it relied more and more frequently on racially charged rhetoric. ${ }^{133}$ Charlton Heston and other NRA figures spoke in libertarian terms, but their arguments were

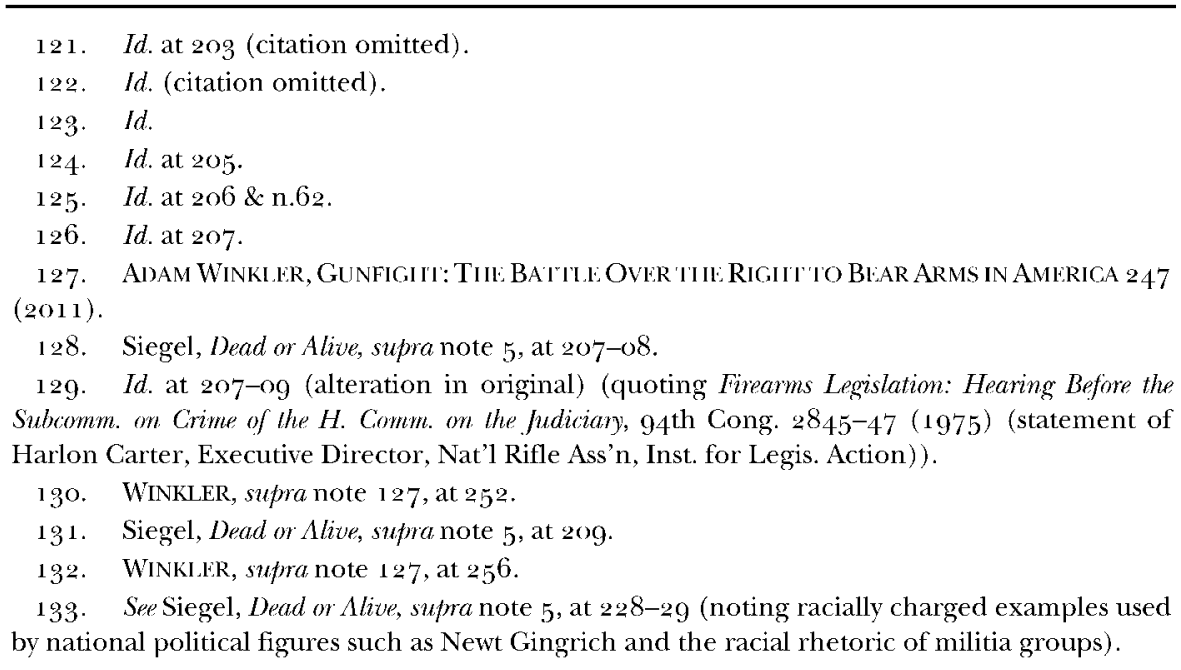


"unmistakably racialized." ${ }_{94}$ Heston and other high-profile NRA members were appealing directly "to white racial consciousness." 195 They actively campaigned for a Second Amendment that did not include feminists, gays and lesbians, and "militant" African-Americans. ${ }^{13^{6}}$ In terms that unmistakably appealed to white gun owners, Heston argued that they were fighting another "civil war, a cultural war that's about to highjack your birthright." 137 These were not arguments for a racially inclusive Second Amendment. In general, fear of black violence, rather than support for black gun rights, drove the NRA's Second Amendment agenda. As gun control became part of the nation's culture wars, it became increasingly clear that the "criminal" classes -by which many gun rights advocates meant African-Americans and other minorities-needed to be disarmed, while law-abiding (white) citizens needed access to firearms for defense of self and family. $19^{8}$

At the critical historical juncture in the 197 os when the "law and order" frame took hold, gun control opponents actually became staunch civil libertarians, who objected to governmental intervention in any form or guise. ${ }^{139}$ They sought a return to a constitutional order rooted in tradition, populism, and racial division. ${ }^{10}{ }^{\circ}$ Their brand of civil libertarianism had troubling racial overtones that "appealed to white racial consciousness." $11^{1}$ Heston and others sometimes spoke in illiberal terms, in particular concerning equality claims by those who did not represent the traditions they were defending. ${ }^{12}$

As Professor Siegel explains, the mobilization for gun rights "grew up in the shadow of civil rights struggle." 143 Modern-day Second Amendment rights are in this sense inseparable from and part of America's civil rights struggle. However, as the "law and order" frame developed, a new Second Amendment began to crystallize. According to Professor Siegel:

$[T]$ his Second Amendment unmistakably carried the memory of civil rights struggle, and with it a deep sense of social division; it imagined society as divided into kinds, the "law-abiding citizen" and the "criminal," the deserving and the undeserving-and resented

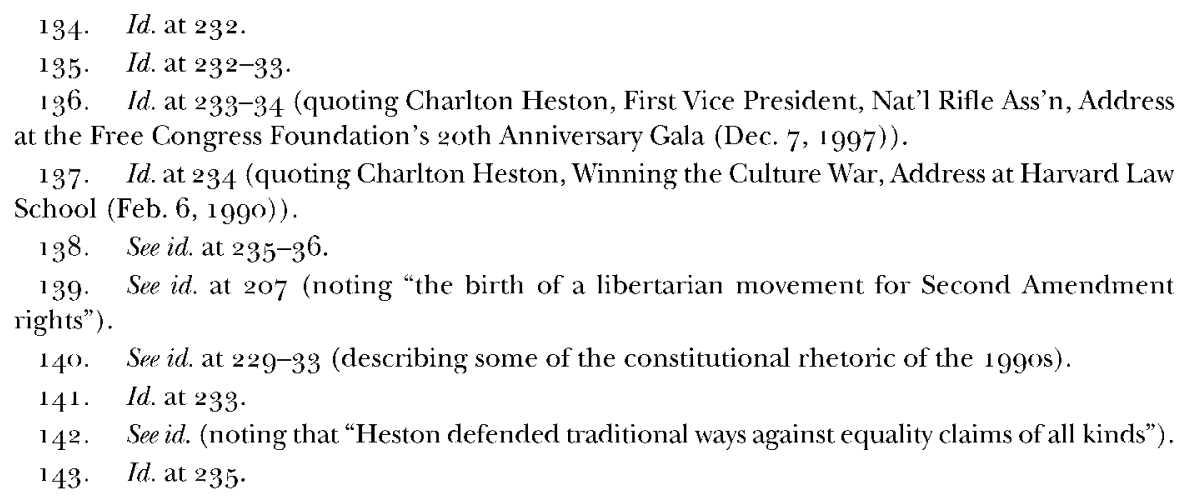


government when it identified with the undeserving other. This lawand-order Second Amendment recalled the founding as the time before the constitutional (un)settlements of the late twentieth century. ${ }^{144}$

In sum, the modern civil rights frame is itself rooted in racial division and strife. Civil rights concerns were an important backdrop for the "law and order" and self-defense interpretations of the Second Amendment the Supreme Court eventually recognized in Heller. ${ }^{145}$ There was a distinctive racial component to this framing. Post-civil rights era gun rights frames were rooted in concerns about protecting the Second Amendment rights of certain segments of the population and disarming the "criminal" other. ${ }^{14}{ }^{6}$

As we will see, today, gun rights proponents attack gun control as a vestige and continuation of a racist tradition. ${ }^{147}$ However, not that long ago, it was the nascent gun rights movement that supported the disarmament of racial minorities. ${ }^{14^{8}}$ While some pointed to the disarming of the Panthers as reason to support a libertarian Second Amendment, other gun rights proponents pointed to the threat civil rights activism posed to society as a reason to recognize an individual right to keep and bear arms for the purpose of selfdefense. ${ }^{149}$

\section{Gun Control's "Ugly History"}

Thus far, we have seen that race played a central role in development of the modern "law and order" framing of the Second Amendment, which resulted in Heller's recognition of an individual right to keep and bear arms. ${ }^{150}$ At the same time, throughout the development of the civil rights frame scholars and gun control advocates also emphasized the discriminatory legacy of gun control measures. ${ }^{15^{1}}$ This includes the early experiences of freedmen and reactions to the societal disruption and rising black radicalism of the postBrown period.

In the run-up to Heller, scholars focused on the long history of racial and other forms of discrimination in the nation's gun laws to develop an explicit

\footnotetext{
144. Id. at $235^{-36 .}$

145. See id. at 194 (noting that "citizens made claims on a Second Amendment concerned with law and order and self-defense").

146. Id. at 214 .

147. See infra Section III.B.3.

148. See WINKL lik, supra note 127 , at $244^{-52}$ (describing backlash against Black Panthers and riots in African-American communities).

149. Siegel, Dead or Alive, supra note 5, at 228.

15 o. See supra Section III.B.1.

151. See generally Cottrol \& Diamond, The Second Amendmenl, supra note 23, at 323 ("There was another reason for the renewed emphasis on the right and duty to be armed in America: race.").
} 
civil rights narrative concerning the Second Amendment. ${ }^{\check{s}^{2}}$ In an early law review article, Professors Cottrol and Diamond relied on the history of slavery, Jim Crow, and the civil rights movement to support an individual rights interpretation similar to the one the Supreme Court would ultimately adopt in Heller. ${ }^{153}$ Their work, which they labeled an "Afro-centric" interpretation of the Second Amendment, relied on gun control's discriminatory past-and present-to argue in favor of an individual right to keep and bear arms. ${ }^{151}$

Cottrol and Diamond drew one of the first explicit links between gun rights and civil rights. The authors argued, "[t] he history of blacks, firearms regulations, and the right to bear arms should cause us to ask new questions regarding the Second Amendment." 55 They concluded that "a re-examination of this history can lead us to a modern realization of what the framers of the Second Amendment understood: that it is unwise to place the means of protection totally in the hands of the state, and that self-defense is also a civil right." ${ }^{16}$

This conception of a "civil right" was of a decidedly modern form: It was rooted in concerns about state and private violence that had been, and according to the authors continued to be, perpetrated against AfricanAmericans and other vulnerable minorities. Gun rights advocates relied on this "Afro-centric" interpretation and used it to frame the Second Amendment in terms of discrimination and equality concerns.

For example, a lawyer in the office of the general counsel of the NRA opened a 1991 law review article advocating for an individual right to keep and bear arms with this observation: "The history of gun control in America possesses an ugly component: discrimination and oppression of blacks, other racial and ethnic minorities, immigrants, and other 'unwanted elements,' including union organizers and agrarian reformers." ${ }_{157}$ Thus, by the early 199os, as some in the gun rights movement developed a civil libertarian interpretation of the Second Amendment that had racial overtones, others simultaneously developed and deployed the argument that racism undermined all efforts at gun control. ${ }^{15} 8$

Scholarship and other commentary drawing the link between gun control and historical racism quickly sprouted up in law reviews and a variety

\footnotetext{
152. Cottrol and Diamond's work was especially important to this framing. See id. at 323-27.

153. See id. at 336-38, 349; see also Cottrol \& Diamond, Never Intended, supra note 23, at 1312 $-14,1325-28$.

154. Cottrol \& Diamond, The Second Amendment, supra note 23, at 319-20, 349 .

155. Id. at 361 .

156. Id. (emphasis added).

157. Stefan B. Tahmassebi, Gun Control and Racism, 2 GHO. Mason U. C.R.L.J. 67, 67 (1991).

158. See id. at $89-85,93-97$ (arguing for heightened scrutiny of all gun regulations because of their racially discriminatory nature).
} 
of other forums. ${ }^{159}$ Thus, the civil rights frame became part of the political and constitutional discourse concerning Second Amendment rights. ${ }^{160}$ Accounts discussed the Second Amendment in a civil rights register that framed gun control as a threat to equality-even though modern gun control laws did not classify based on race or other suspect characteristics, and even though most firearms owners were white and male. ${ }^{161}$

Advocates pressed the discrimination frame in public discourse and court filings. Briefs filed in both Heller and McDonald drew specific attention to the connection between the right to keep and bear arms and the "ugly history" of African-American disarmament. ${ }^{162}$ Gun rights advocates pointed to the undeniable fact of racial discrimination in the nation's earliest gun laws, the disarming of oppressed populations, and other discriminatory gun control measures. ${ }^{169}$ The civil rights framing even extended to the choice of plaintiffs in both Heller and McDonald. Lead counsel for plaintiffs challenging the D.C. and Chicago gun control laws, respectively, sought out diverse plaintiffs, in particular African-Americans, to advance their claims. ${ }^{16_{1}}$ By presenting claims by African-Americans denied the right to defend themselves in their homes,

159. See, e.g., Haydn J. Richards, Jr., Redefining the Second Amendment: The Antebellum Rights to Keep and Bear Arms and IIs Presenl Legacy, 91 KY. L.J. 31 1, 351 (2002) ("By disarming their enslaved populations, southern whites maintained social control throughout their society."); Cynthia Deitle Leonardatos, California's Attempts to Disarm the Black Panthers, 36 SAN DIlGo L. Rlv. 947, 949 (1999) ("If California can pass a gun control statute in order to disarm a specifically identified, politically distasteful, minority group, is any class of citizens safe from being left defenseless in the future?"); Clayton E. Cramer, The Racist Roots of Gun Control, 4 KAN. J.L. \& PUB. POL'Y, Winter 1995, at 17. Some commentators also charged that law enforcement officials were selectively enforcing gun laws. See Bonita R. Gardner, Separate and Unequal: Federal Tough-on-Guns Program Targets Minority Communities for Selective Enforcement, 12 MiCII. J. RACl \& L. 305, 313-17, $327,343(2007)$.

16o. See, e.g., The Racist Histony of Handgun Bans in America, NRA-ILA (Jan. 15, 2003), https:// www.nraila.org/articles $/ 20090115$ /the-racist-history-of-handgun-bans-in-a [https://perma.cc/ TR7Q-AZX6].

161. See David C. Williams, The Mythic: Meanings of the Second Amendment: Taming: POLITICAL VIOLENCE IN A CONSTITITIIONAL REPI IBLIC I 75 (2003) ("[T] he gun culture has a core constituency-white, rural males with conservative values, especially in the South."); see also FRANKs, supra note 116 , at $65^{-67}$ (discussing the white, Christian victimhood narrative relating to gun control).

162. See, e.g., Brief of Amicus Curiae Congress of Racial Equal. in Support of Respondent, District of Columbia v. Heller, 554 U.S. 570 (2007) (No. 07-290), 2008 WL 345\%44, at * 10 ; Brief of Amicus Curiae Jews for the Pres. of Firearms Ownership in Support of Petitioners, McDonald v. City of Chicago, $5^{6} 1$ U.S. 742 (2015) (No. 08-1521), 2009 WL $40995^{11}$, at "3.

163. See Brief of Amicus Curiae Congress of Racial Equal. in Support of Respondent, supra note 162 , at *4. See generally Brief of Amicus Curiae Jews for the Pres. of Firearms Ownership in Support of Petitioners, supra note 162 , at * 3 (discussing how the history of disarmament has led to mass genocide of oppressed populations).

164. BLOCHER \& MILLER, supra note 34, at 67; WINKLER, supra note 127 , at 60. 
advocates conjured historical images of freedmen unable to defend themselves against the violence of rogue militias and the Ku Klux Klan. ${ }^{165}$

There is some evidence that this public civil rights framing of the Second Amendment had an effect on the Supreme Court in both Heller and McDonald. The Heller Court pointed to the disarming of freedmen as one reason to adopt an individual rights interpretation of the Second Amendment rooted in self-defense. ${ }^{66}$ Although the McDonald Court rejected the premise that anti-discrimination was the sole animating force behind the Fourteenth Amendment, it acknowledged that racial discrimination-including in connection with arms possession-was a particular concern at that time..$^{167}$ The Civil Rights Act of 1866 and the Fourteenth Amendment may not have been adopted "simply to prohibit discrimination," as the Court noted, but that was plainly one of the purposes of these enactments. ${ }^{168}$ In concluding that the Second Amendment is a "fundamental right" worthy of incorporation against the states, the Court relied heavily on the historical link between racial equality and the right to keep and bear arms. ${ }^{1 \text { tigg }}$ The majority alluded to this "ugly history" in response to Justice Breyer's argument "that the Second Amendment right does not protect minorities and those lacking political clout." ${ }^{7}$ o To the contrary, the Court argued, the right to keep and bear arms is critically important to the protection of racial minorities and other vulnerable groups in what it referred to as "high-crime areas." "7r In a lengthy concurrence, Justice Thomas also focused explicitly on the "ugly history" of gun control. ${ }^{172}$

The Supreme Court did not expressly adopt advocates' arguments that modern gun control measures were direct descendants of the Black Codes and Jim Crow. However, it relied on aspects of the early "ugly history," the law and order trope of "high crime areas," and the equality concerns about racial and other minorities. ${ }^{173}$ This is an illustration of how the gun rights movement and its public narratives influenced official-in this particular instance, judicial-interpretations of the Second Amendment.

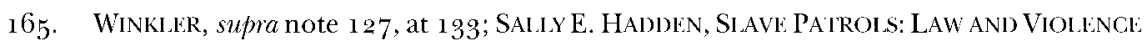
IN VIRGINIA AND THIL CAROIINAS 3-4, $211-12$ (2001).

166. Heller, 554 U.S. at $614^{-16 .}$

167. Moldomald, 561 U.S. at $778-80$.

168. See Stephen P. Halbrook, The furispmudence of the Second and Fourteenth Amendments, 4 GEO. MASON U. L. REV. xvi, 19-21 (1981) (linking the Fourteenth Amendment in part to protecting the right of newly freed slaves to possess arms).

169. See McDonald, 561 U.S. at $771-76,778$ (discussing concerns about disarmament of freedmen).

170. Id. at 789 .

171. Id. at 790 .

172. See id. at $844-58$ (Thomas, J., concurring in part).

173. Id. at $789-90$ (majority opinion).
} 


\section{3. "Gun Control is Racist"}

Having achieved recognition of an individual right to keep and bear arms in Heller and incorporation in McDonald, one might have expected advocates to reduce or discontinue their reliance on a distinctive civil rights frame. Early scholarship and commentary on race and arms had largely been devoted to judicial recognition of an individual Second Amendment right, and that was what Heller and McDonald had produced. ${ }^{171}$

However, gun rights advocates seem instead to have increased their reliance on the civil rights narrative after Heller and $M c$ Donald. ${ }^{75}$ The tone and tenor of the discrimination frame grew sharper and broader and consisted of some outlandish claims about gun control. The civil rights frame transformed from an argument rooted in the specific history of discrimination to a narrative that contended all forms of gun control are "racist." For example, in 2009, the year after the Court handed down Heller, a commentator proclaimed, "[t] he history of gun control in America is undeniably racist and discriminatory." ${ }^{166}$ After $M c$ Donald, online articles with titles like "Gun Control is Racist," "The Racist History of Gun Control," or even more insistently, "The (Really, Really) Racist History of Gun Control in America," began to appear with increasing frequency. ${ }^{177}$

174. See, eg., District of Columbia v. Heller, 554 U.S. 570, 595 (2008) (recognizing an individual right to keep and bear arms).

175. See Ladd Everitt, Dehunking the 'Gun Control is Racist' Smear, Waging Nonviollince (Sept. 16, 2010), https://wagingnonviolence.org/2010/og/debunking-the-gun-control-is-racist-smear [https://perma.cc/ $\mathrm{V}_{3} \mathrm{~S}_{5}$-RBFX] (observing that after MclDonald, "the 'gun control is racist' argument $[$ wa $]$ s all the rage").

176. David Babat, The Discriminatory History of Gun Control 18 (2009) (Senior Honors Project, University of Rhode Island), https://digitalcommons.uri.edu/cgi/viewcontent.cgi? article $=114$ 2\&context=srhonorsprog [https: / perma.cc/V572-UCJD]. The author makes two different equality claims, one based on race and the other on wealth. See id. at 22. He does not rely on any explicit targeting of particular owners or possessors of arms, but on the allegedly disparate impact of arms regulations. See generally id. (relying on allegedly disparate impact of arms regulations).

177. For a sample of these claims, see Natasha Lennard, Gun Control IIas Always Been Racist -That Doesn't Mean We Shouldn't Support the Parkland Students' Movement, INTERCEPT (Mar. I, 2018, 12:29 PM), https://theintercept.com/2018/03/o1/florida-shooting-gun-control-police [https://perma.cc/C8Q8-569S]; Tho Bishop, The Racist History of Gun Control, Mists InsI. (May 22, 2018), https://mises.org/wire/racist-history-gun-control-1 [https://perma.cc/Q6T6-JHMU]; Brentin Mock, Will Pittshurgh's Gun Control Lazis Get More Blach P'eople Killed?, Bioombira CirYLAB (Mar. 11, 2019, 11:30 AM), https://www.citylab.com/equity/2019/o3/gun-controllaws-pittsburgh-racial-equity-ending-violence $/ 584458$ [https://perma.cc/ $\mathbf{U}_{5} \mathrm{RQ}-5 \mathrm{NDC}$; Emmanuel Sessegnon, The Racist History of Gun Control, LibliRTARIAN Rlipubi.IC (Dec. 28, 2018), https://thelibertarianrepublic.com/the-racist-history-of-gun-control $\left[\mathrm{https} / /\right.$ perma.cc $/ 6 \mathrm{H}_{3} \mathrm{~K}-$ TQTX]; Jayel Aheram, Gun Comtrol is Racist, Young AMS. FOR LIBERTY, https://yaliberty.org/ news/gun-control-is-racist [https://perma.cc/ $\left.{ }_{4} \mathrm{~B}_{4} \mathrm{Y}-\mathrm{M}_{75} \mathrm{Y}\right]$; Jane Coaston, The (Really, Really) Racist History of Gun Control in America, MTV: Niws (June 30, 2016), http://www.mtv.com/ news/2900230/the-really-really-racist-history-of-gun-control-in-america [https://perma.cc/ GF6N-WHKV]; David Rittgers, Nalional Review: Gun Control Doesn'l Work, NPR (June 29, 2010, $8: 38$ AM), https://www.npr.org/templates/story/story.php?storyld=128186209 [https:// 
The Supreme Court's partial embrace of the equality narrative may have encouraged or emboldened gun rights advocates to make these sorts of arguments. Whatever the impetus or cause, the civil rights frame moved beyond reliance on historical evidence like that relied on by Cottrol and Diamond. Instead, it condemned gun control measures as irredeemably tainted by racism, whether or not there was any actual evidence of racial animus. This was not a warning to avoid repeating the mistakes of the past, or an argument supporting an individual right to keep and bear arms. It was an argument that current-and presumably future-gun control laws were all direct descendants of Jim Crow.

In both its formal and more outlandish articulations, the civil rights frame became prevalent on the internet, in social media and other digital forums, and publications. ${ }^{178}$ As a constitutional shorthand or meme, it is plainly suited to the digital era. However, it also has some mainstream support in the gun rights movement. The NRA, which has falsely referred to itself as "the largest and oldest civil rights organization in America," 179 has advanced this civil rights narrative. The group has sometimes done so subtly, by highlighting the organization's concern for gun rights "regardless of race, religion or sexual orientation." 180 However, adopting the more outlandish form, the NRA has also produced media materials that claim modern gun regulations "are 'equally as unconstitutional' as Jim Crow laws." ${ }_{181}$

The NRA has relied on purported analogies between gun control laws and segregation-era measures that purposefully denied African-Americans' constitutional rights. For example, an NRA lobbyist referred to a Seattle ordinance that would have imposed a tax on gun and ammunition sales in order to fund research on gun violence as "a poll tax." 18 ? The NRA also

perma.cc/55QP-VT8W]; and Clarence Page, Race Cases Win Gun Rights for All, CHI. TRIB. (July 7, 2010), https://www.chicagotribune.com/news/ct-xpm-2010-07-07-ct-oped-o7o7-page20100707-story.html [https://perma.cc/HQ7.J-K5 $\mathrm{G}_{5}$ ].

178. See sources cited supra note 177.

179. See Rowan Morrison, NRA Official Dubs It 'Largest and Oldest Civil Rights Association' in US, TPM (July 19, 2016, 9:20 PM), https://talkingpointsmemo.com/livewire/chris-cox-nra-oldestcivil-rights-group-in-us [https://perma.cc/F69M-QV23] (quoting NRA's Chris Cox).

180. Id.

181. Timothy Johnson, NRA: Gun Regulations Are "Equally as Unconstitutional" as fim Crow Laws, MEDL MATTERS FOR AM. (July 8, 2014, 1:20 PM), https://www.mediamatters.org/blog/2014/ $07 / 08 /$ nra-gun-regulations-are-equally-as-unconstituti/200022 [https://perma.cc/XZW 7-VJ2M]; Timothy Johnson, National Rifle Association: Assault Weapons Bans Involve a "Form of Tactical Jim Crow-Style Segregation," MEDI MATTERS FOR AM. (July 24, 2015, 1:17 PM) [hereinafter Johnson, Assault Weapons Bans], https://www.mediamatters.org/blog/2015/o7/24/national-rifleassociation-assault-weapons-bans/204581 [https://perma.cc/PUS $4-\mathrm{MF}_{47}$ ]; Timothy Johnson, Latest NRA Talking Point: Opponents of New Colorado Gun Lawe Are Like Victims of Racial Segregation, MEDIA MAT'TliRS FOR AM. (Jume 5, 2019, 2:24 PM), https://www.mediamatters.org/blog/2013/ 06/05/latest-nra-talking-point-opponents-of-new-color/194356 [https://perma.cc/427 D-649Z].

182. Timothy Johnson, NRA Flack Calls Sealle's New "Gun Violence Tax" a "Poll Tax," MididA MATTIRS FOR AM. (Aug. 25, 2015, 2:30 PM), https://www.mediamatters.org $/ \mathrm{blog} / 2015 /$ $08 / 25 /$ nra-flack-calls-seattles-new-gun-violence-tax-a/205139 [https://perma.cc/5 A6E-76BQ]. 
described assault weapons bans as "a form of tactical Jim Crow-style segregation" and argued that gun owners are presently experiencing the same kinds of dignity, equality, and other harms inflicted on African-Americans victimized by racial segregation. ${ }^{183}$ Outspoken gun rights advocates like Ted Nugent, who has served as an NRA board member, have compared beleaguered gun owners to Rosa Parks. ${ }^{18} 1$ On social media, gun rights groups have sought to co-opt the language of contemporary civil rights advocates, such as participants in Black Lives Matter, by forming groups with names like "Gun Rights Matter" and "Black Guns Matter." ${ }^{8} 8_{\breve{\jmath}}$

Proponents of this Second Amendment frame have received a significant boost from some prominent spokespersons. These include former Secretary of State Condoleezza Rice, who claims that she became a "Second Amendment absolutist" owing to concerns about disarming AfricanAmericans, including her own father, during the civil rights movement, ${ }^{186}$ and Senator Rand Paul, who has articulated a similar Second Amendment civil rights narrative in public comments.

A new generation of scholars has updated or propounded new "Afrocentric" and equality-based accounts of the Second Amendment. ${ }^{187}$ In response to calls for gun control measures, including in response to mass shootings, gun rights advocates have insisted that proposed arms regulations are inherently suspect owing to their "racist" history. ${ }^{188}$ Referencing this history, advocates have continued to broadcast dire warnings of the "dark side" of gun control. ${ }^{189}$ They have argued that American history demonstrates

"Poll taxes," or fees charged as a prerequisite to voting, have been described as "one of the great symbols of Southern racism." Bruce Ackerman \& Jennifer Nou, Canomizing the Ciril Rights Revolution: The People and the Poll Tax, 109 Nw. U. L. REV. 63, 65 (2009). The Twenty-fourth Amendment abolished use of the poll tax in federal elections. U.S. CONSI. amend. XXIV, $\$ 1$.

183. Johnson, Assault Weapons Bans, supra note 181.

184. Ben Dimiero, Ted Nugent Calls Gun Owners the Next Rosa Parks, MEdi MATTERS For AM. (Jan. 10, 2013, 9:19 AM), https://www.mediamatters.org/blog/2013/o1/10/ted-nugentcalls-gum-owners-the-next-rosa-parks/ 192149 [https://perma.cc/5D33-TY9T].

185. See Gun Rights Matter, supra note 27; BLACKGUNsMATTER, https://blackgunsmatter. myshopify.com [https://perma.cc/8N26-TJMX].

186. See David Kopel \& Joseph Greenlee, The Racist Origin of Gun Control Laus, Hit.L. (Aug. 22, 2017,11 :00 AM), https://thehill.com/blogs/pundits-blog/civil-rights/347324-the-racist-originof-gun-control-laws [https://perma.cc/AZE 2-HH2X].

187. See, e.g., Nicholas J. Johnson, Firearms Policy and the Black Community: An Assessment of the Modern Orthodoxy, 45 ConN. L. Rliv. 1491, 1498 (2019) ("Black distrust of the state is well earned.").

188. E.g., David Kopel, The Klan's Favorite Law, REASON (Feb. 15, 2005, 12:00 AM), https:// reason.com/2005/o2/15/the-klans-favorite-law [https://perma.cc/388U-ZCZW].

189. See Creede Newton, Gun Comlrol's Racist Pasl and Present, AL Jazllika (Oct. 6, 2017), https://www.aljazeera.com/indepth/features/2017/10/gun-control-racist-present- 171006135 904199.html [https://perma.cc/EGg8-BKZ3]; Robert Farago, FARAGO: Racist Pols Go Straight Back to Disarming Blacks, WASII. Timis (July 6, 2010), https://www.washingtontimes.com/ news $/ 2010 / \mathrm{jul} / 6 /$ racist-pols-go-straight-back-to-disarming-blacks. 
gun control laws place African-Americans in special danger of being victims of both official and private forms of violence. 190

Versions of the "gun control is racist" claim have also appeared in court filings. In a recent Second Amendment case dismissed by the Supreme Court as moot, an amicus curiae brief filed by the National African American Gun Association made the claim that a New York City law that restricts the transport of firearms to homes outside city limits "is [h] eir to [r]estrictive [1]icensing in the Jim Crow and [a]nti-[i]mmigrant [e]ras." ${ }^{991}$ This narrative is not limited to racial discrimination. In another brief filed in the same case, members of the "Pink Pistols" group argue that LGBTQ persons have a special stake in the Second Amendment right to self-defense, again owing in part to a history of discrimination. ${ }^{19^{2}}$

By branding all forms of gun control as "racist," gun rights advocates hope to influence public discourse about and official interpretations of the Second Amendment. ${ }^{193}$ This narrative advances the argument that courts and officials are relegating the Second Amendment to "second-class" status. ${ }^{191}$ In this form, the civil rights frame may encourage judicial skepticism, provide lawmakers an effective narrative for gun rights legislation, and influence public discourse concerning gun rights and gun control. The civil rights frame changes the focus of that discourse from the individual (white) gun owner to the oppressed minority seeking equal protection of the laws. ${ }^{195}$

\section{Firearms and the Civil Rights Movement}

There is a final aspect of the Second Amendment civil rights narrative that bears special attention. Related to the "ugly history" and "gun control is racist" narratives is an effort to connect the civil rights movement to the modern gun rights movement. There are three claims supporting this part of the civil rights frame. The first is that gun control measures enforced during and in response to the civil rights movement were themselves racially discriminatory. ${ }^{196}$ The second claim emphasizes the role access to firearms

190. See Kopel \& Greenlee, supra note 186 ("Guns have historically protected Americans from white supremacists, just as gun control has historically protected white supremacists from the Americans they terrorize.").

191. Brief for Amicus Curiae Nat'l African Am. Gun Ass'n, Inc. in Support of Petitioners, N.Y. State Rifle \& Pistol Ass'n., Inc. v. City of New York, 140 S. Ct. 1525 (2020) (No. 18-280), 2019 WL 2103434 , at ${ }^{*} 34$.

192. See id.; Brief Amicus Curiae of Pink Pistols in Support of Petitioners, N.Y. State Rifle \& Pistol Ass'n., Inc. v. City of New York, 140 S. Ct. $15^{25}$ (2020) (No.18-280), 2019 WL 2121721 , at*1.

193. Cf. Siegel, The Righ's Reasoms, supra note 66, at 1642 (describing an "abortion harms women" frame, which provides a "woman-protective rationale for restricting abortion").

194. See generally Zick, supra note 15 (analyzing claims by gun rights proponents that courts have treated Second Amendment claims as "second-class").

195. See Siegel, The Righl's Reasons, supra note 66, at 1649 (noting how the woman-protective abortion frame changes the narrative from "Abortion kills a baby" to "Abortion hurts women").

196. See WINKLER, supra note 127 , at $247^{-55}$ (discussing California and federal laws). 
played in the success of the civil rights movement. ${ }^{197}$ The third claim is that courts are currently denying gun owners' civil rights by subjecting them to "second-class" treatment under the law. ${ }^{198}$

The "ugly history" and "gun control is racist" narratives derive in part from and rely upon the role firearms played during the civil rights movement. 199 As discussed earlier, gun control advocates have argued that early gun control measures, such as California's Mulford Act and the federal Gun Control Act of 1968 , were products of racist politics. ${ }^{200}$ Indeed, California adopted the Mulford Act to reign in the militant Black Panthers, who openly-and lawfully-carried firearms in public. account, federal legislators enacted the federal gun control law based on concerns about the Panthers as well as several urban race riots that shook the nation in the late $19605 .{ }^{202}$

Although the NRA was an early supporter of these measures, as already discussed, ${ }^{203}$ the organization's leadership and position changed owing to concerns about disarming law-abiding citizens faced with the threat of criminal violence and public disorder during the 1960 os and $197^{\circ 05} .^{201}$ Notwithstanding the complex racial politics associated with the "law and order" narrative, gun rights advocates have emphasized the importance of arms to African-Americans and other marginalized groups, pointing specifically to the civil rights movement as an example. ${ }^{205}$

The Second Amendment civil rights frame generally extolls the virtues of armed empowerment as a means of protecting equality. ${ }^{206}$ Glancing backwards, the narrative contends that in the face of lynching and other

197. See, e.g., id. at 105-o6 (recounting stories of armed activists); Cottrol \& Diamond, The Second Amendment, supra note 23 , at $33^{6-38}$.

198. See generally Zick, supra note 15 (examining "second-class" claims as a matter of constitutional doctrine); Eric Ruben \& Joseph Blocher, "The Second Amendment is Not a SecondClass Right": Constitutional Rhetoric and Doctrinal Change (June 19, 2020) (unpublished manuscript) (on file with author) (examining rhetoric of "second-class" claims).

199. See AknNyele OMownle Umoja, We Will Shoot Back: ARmed Resistancie in the Mississitpi Freedom Movement 1 45-2 10 (2013); Simon Wendt, The SPIRIT 4 Nd the Shotgun:

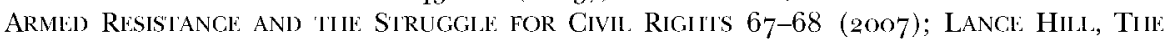
DEACONS FOR DEFENSE: ARMED RESISTANC:E AND THE CIVIL RIGHTS MOVEMENT 251-52 (2004).

200. Sep Winkt ler, supra note 127, at 247-55 (discussing California and federal laws).

201. Id. at 247 (citing "backlash against armed blacks").

202. Id. at 249-51; see also Cramer, supra note 159 , at 21 (linking the Gun Control Act

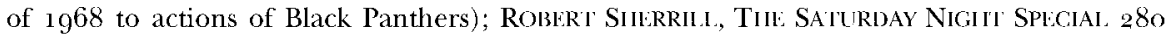
(1979) (linking efforts to control access to "Saturday Night Special" to race and economic discrimination).

203. See discussion supra Section III.B.1.

204. See "law and order" narrative discussion supra Section III.B.1 .

205. See generally sources cited supra note 23 (exploring firearms regulation and racial disparity); HILL, supra note 199 (crediting success of the civil rights movement to armed resistance of the Deacons).

2o6. See BLOCHER \& MILLER, supra note 34, at 166. 
threats of violence during the nineteenth and early twentieth centuries, only access to firearms gave freedmen a fighting chance. ${ }^{207}$ It posits that if freedmen and African-Americans had been properly armed, things might have turned out differently.

Broadening this historical frame, some gun rights advocates credit the actual success of the civil rights movement of the $195^{\circ}$ os and 1960 s to activists' access to firearms. Thus, scholars have noted instances in which AfricanAmericans armed themselves and stood guard at the homes of civil rights activists. ${ }^{208}$ They have focused in particular on the actions of armed security personnel, known as the "Deacons for Defense and Justice." "oog According to the narrative, the Deacons deterred vigilante and other forms of violence against African-Americans in general and provided critical armed security to Dr. Martin Luther King, Jr. (who himself once sought, unsuccessfully, to purchase a handgun). ${ }^{210}$ They also provided security to others involved in the civil rights movement..11 As the historian Akinyele Omowale Umoja has observed, "armed resistance was critical to the efficacy of the southern freedom struggle and the dismantling of segregation and Black disenfranchisement." ${ }^{12}$

Finally, gun rights advocates have used the rhetoric and history of the civil rights movement to criticize how courts-including the Supreme Court-have treated gun rights claimants and Second Amendment claims. Commentators, litigants, and some judges have invoked "second-class" terminology to challenge lower court interpretations of Heller and chastise the Supreme Court for failing to review lower court decisions upholding gun regulations. ${ }^{219}$ They have asserted that lower courts have treated the Second Amendment as a "second-class right," engaged in massive resistance to Heller

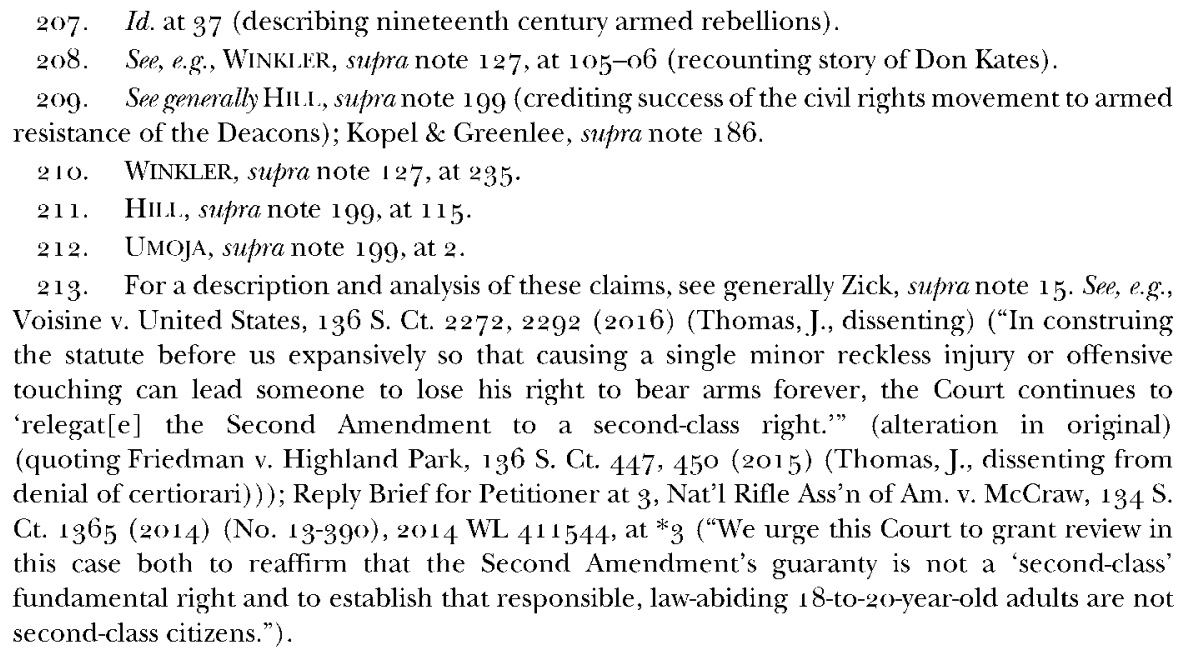
the statute before us expansively so that causing a single minor reckless injury or offensive touching can lead someone to lose his right to bear arms forever, the Court continues to "relegat $[\mathrm{e}]$ the Second Amendment to a second-class right." (alteration in original) (quoting Friedman v. Highland Park, 136 S. Ct. 447, 450 (2015) (Thomas, J., dissenting from denial of certiorari)) ); Reply Brief for Petitioner at 3 , Nat'l Rifle Ass'n of Am. v. McCraw, ${ }_{34} \mathrm{~S}$. C. 1365 (2014) (No. 13-390), 2014 WL 411544 , at *3 ("We urge this Court to grant review in this case both to reaffirm that the Second Amendment's guaranty is not a 'second-class' fundamental right and to establish that responsible, law-abiding 18-to-20-year-old adults are not second-class citizens."). 
and the Second Amendment, and relegated the Second Amendment "to the back of our constitutional bus." 214

In sum, gun rights advocates have invoked the civil rights experience, along with earlier race-based deprivations of gun rights, to advance the Second Amendment civil rights narrative or frame. Along with the "ugly history" and "gun control is racist" narratives, this argument deploys civil rights vocabulary and concerns in an effort to taint and discredit all gun control measures.

\section{CIVIL RIGHTS COUNTER-FRAMES}

In democratic constitutionalism, activists often answer social movement mobilization with counter-mobilization. ${ }^{25}$ Relatedly, in constitutional debates, advocates often answer frames with counter-frames. ${ }^{216}$

With regard to the civil rights framing of the Second Amendment, gun control advocates have mostly played defense. That is, they have focused primarily on trying to debunk the factual and other claims of the "ugly history" and "gun control is racist" narratives advanced by gun rights advocates. ${ }^{217}$ However, gun control proponents have also invoked civil rights arguments. ${ }^{218}$ Some have argued that expansive gun rights actually harm African-Americans and other marginalized individuals. ${ }^{19}$

Others have advanced more systematic race and equality counternarratives. For example, some scholars have argued that the Second

\footnotetext{
214. See Alice Marie Beard, Resislance by Inferior Courts to Supreme Courl's Second Amendment Decisions, 81 TENN. L. REv. 673, 679 (2014) ("In the wake of the Supreme Court's District of Columbia $v$. Ieller... and Mclonald $v$. Chicago decisions that clarify, expand, and protect Second Amendment rights, federal and state inferior courts have been engaging in massive resistance." (citations omitted)); Massive Cun Resistance; State Rifle Bans are in Plain Defiance of the U.S. Supreme Court, WhLL ST. J. (Apr. 12, 2013), https://www.wsj.com/articles/SB10001424 127887324600704578402760760473 [https://perma.cc/YQ7N-UJ5E]; Alan Gura, The Second Amendment as a Normal Right, 127 HARV. L. REV. F. 229,224 (2014) (drawing explicit comparisons between post-Ilellerdecisions and resistance to the Court's decision in Brown $v$. Board of Education); David B. Kopel, Does the Second Amendment Protect Firearms Commerce?, 127 HARV. L. Riv. 29o, 290 (2014); John Yoo \& James C. Phillips, The Second(-Class) Amendment, NAT'L Rev. (Nov. 19, 2018, 6:30 AM), https://www.nationalreview.com/2018/11/supreme-court-secondamendment-rights (arguing that the Second Amendment has been relegated "to the back of our constitutional bus").

215. See Siegel, Constitutional Culture, supra note 8, at $13^{62}$ (discussing social movement counter-mobilizations).

216. See Benford \& Snow, supra note 9, at 625-26 (discussing counter-framing). Gun control counter-framing is discussed in more detail in Section V.B.

217. L.g., Everitt, supra note 175.

218. Sep Stepman, supra note 22 ("Gun rights and civil rights, historically, have gone hand in hand."); Singleton, Ron Paul Classic, supra note 22; Singleton, Second Amendmenl, supra note 22.

219. See, e.g., Selwyn Roger, Jr., Gun Violence is a Civil Rights Issue, CHI. TRIB. (Dec. 8, 2017), https://www.chicagotribune.com/opinion/commentary/ct-perspec-guns-violence-trauma-civilrights-1210-20171207-story.html (claiming " $[\mathrm{g}]$ un violence is an issue of civil rights that threatens lives in our communities daily").
} 
Amendment is itself illegitimate, owing to its connection to slavery and the Black Codes. ${ }^{200}$ Although others have presented it, Professor Carl Bogus is most closely associated with "the Second Amendment is racist" narrative."21 Professor Bogus bases this account on what he claims "is strong evidence that the Second Amendment was intended, in large part at least, to serve as an instrument of slave control." ${ }_{222} \mathrm{He}$ argues that "armed militias were principally used to deter and suppress America's first race riots-slave insurrections." 223

Professor Bogus argues that we ought to "treat[] the Second Amendment as an anachronism, in much the same manner that we treat the provision that counts a slave as three-fifths of a person for purposes of determining the number of congressional representatives for each state." ${ }^{2} 4$ He argues that the lesson of the early history of racist gun control measures "and [modern] experience is not that blacks should be armed, but that all citizens should be subject to stricter gun control regulations." ${ }_{225}$

As others have observed, this historical narrative over-claims. ${ }^{226}$ As discussed, states and the national government denied African-Americans access to firearms during slavery and in antebellum periods. ${ }^{227}$ Militias also sometimes suppressed slave revolts. ${ }^{228}$ However, the historical evidence does not support the claim that this was their sole or even primary purpose. ${ }^{229}$ Nor does it establish that those who supported ratification of the Second Amendment did so in order to protect and preserve the institution of

220. See, e.g., Carl T. Bogus, Was Slavery a Factor in the Second Amendment?, N.Y. Timls (May 24, 2018), https://www.nytimes.com/2018/05/24/opinion/second-amendment-slavery-jamesmadison.html [https://perma.cc/F9PK-S22G]. Professor Bogus first presented this argument in a law review article published in 1998. See generally Carl T. Bogus, The IIidden Ilistory of the Second Amendment, 31 U.C. DAvIS L. Rlv. 309 (1998) [hereinafter Bogus, Hidden Histmy] (theorizing about a "hidden history" of the Second Amendment). For some recent rejoinders to the "Second Amendment is racist" argument, see Charles C.W. Cooke, An Uncontinining Case That Slavery Taints the Second Amendment, NAI'l. Riv. (May 25, 2018), https:// www.nationalreview.com $/ 2018 / 0_{5} /$ second-amendment-slavery-nyt-piece-misleading-claims; and Stephen P. Halbrook, The Second Amendment IIad Nothing to Do With Slavery, Fox News (June 22, 2018), https://www.foxnews.com/opinion/the-second-amendment-had-nothing-to-dowith-slavery [https://perma.cc/HQD 4 -WTLN].

221. See Bogus, Hidden Histmy, supra note 220, at 318, 321 ; David C. Williams, Constitutional Tales of Violence: Populists, Outgroups, and the Multicultural Landscape of the Second Amendment, 74 TuL. L. Riv. $3^{8} 7$ (1999); Thom Hartmann, The Second Amendment Was Ratified to Preserve Slavery, Truthout (Jan. 15, 2019), www.truth-out.org/news/item/1989o-the-second-amendment-wasratified-to-preserve-slavery [https://perma.cc/9XK6-YWL2].

222. Carl T. Bogus, Race, Riots, and Cuns, 66 S. CAL. L. REV. 1365, 1367 (1993).

223. Id.

224. Id.

225. Id.

226. See Blocine \& Millir, supra note 34 , at $35^{-36}$.

227. See discussion supra Section III.A.

228. BLOCHER \& MLLLR, supra note 34 , at 35-36.

229. Id. 
slavery. $93^{\circ}$ That does not mean the militia had nothing to do with the perpetuation of slavery or the enforcement of the Black Codes.231 It simply means that we cannot delegitimize the Second Amendment as the product of racism.

Like the civil rights narrative, the "Second Amendment is racist" argument is a rhetorical tool. However, the historical connection between race and arms is far too complex and nuanced for this type of blunt framing device. The counter-narrative appears never to have attracted meaningful support in public discourse. By recognizing an individual right to bear arms, Heller repudiated any notion that the Second Amendment is an illegitimate product of slavery and racism. Indeed, as noted, it adopted aspects of the civil rights frames advanced by gun rights advocates.9.2

\section{THE CIVIL.RIGHTS AGINIDA}

As noted earlier, one of the purposes of creating and communicating the civil rights narrative was to convince the Supreme Court to recognize an individual, as opposed to militia-based, right to keep and bear arms.. ${ }^{23}$ Another was to press for incorporation of the Second Amendment. ${ }^{231}$ Even after the successes in Heller and McDonald, gun rights proponents continue to advance the civil rights frame.935 There are likely several reasons for their continued reliance on the anti-discrimination narrative.

First, advocates are deploying the civil rights narrative to help legitimize the gun rights movement and the Second Amendment right to keep and bear arms. Litigants and commentators who invoke Jim Crow, Brown, Rosa Parks, and Martin Luther King, Jr. hope to connect the race equality and gun rights movements. By connecting gun rights to the broadly popular and successful civil rights movement and to anti-discrimination norms, proponents hope to garner official and public support for their cause and to produce additional Second Amendment victories in the courts.

Second, and relatedly, gun rights advocates have used the civil rights frame to cast a cloud of skepticism over gun control measures, by tainting them with an "ugly history" of discrimination against African-Americans, immigrants, and other politically marginalized persons. ${ }^{296}$ Gun rights proponents have invoked this history to emphasize the "dark side" of gun control, argue "gun control is racist," and complain of "second-class"

\footnotetext{
230. See id. at 36 ("At most, it could be said that the militia was intended to put down rebellions, whether that be a slave revolt in the South or Shay's Rebellion in the North.").

231. See WINKLER, supra note 127, at 133 (discussing role of militias during Reconstruction).

232. See discussion supra Section III.A.

233. See discussion supra Section III.B.1.

234. See McDonald v. City of Chicago, $5^{61}$ U.S. $74^{2}, 75^{\circ}$ (2010) (holding the Second Amendment applicable to states).

235. See discussion supra Sections III.B.2-.3.

236. See discussion supra Section III.B.2.
} 
treatment in the courts. ${ }^{937}$ Advocates have used this rhetoric to encourage Americans to question governmental motives when it comes to gun control. They have also deployed it to breed particular suspicion among AfricanAmericans that officials are targeting them for discriminatory reasons.

Third, gun control advocates have used civil rights framing to justify skeptical and strong forms of judicial review of gun control regulations. One justification for heightened scrutiny is that it is necessary to protect the constitutional rights of marginalized individuals-so-called "discrete and insular minorities." ${ }_{238}$ The majority in McDonald invoked this argument and Justice Thomas echoed its concerns in his separate concurrence. ${ }^{299}$ The vast majority of gun owners are white and male. ${ }^{20}$ Nevertheless, litigants and some scholars have invoked civil rights arguments to justify heightened scrutiny of all gun control measures. ${ }^{241}$ "Second-class" arguments seek a similar result. They use the specter of judicial "discrimination" or bias to drive up judicial scrutiny of gun control measures. ${ }^{2}{ }^{2}$

Fourth, as discussed further below, casting the Second Amendment as a "civil right" makes it more likely that legislatures will provide affirmative legal protections for gun owners and sellers. ${ }^{213}$ This has been a common feature

237. See discussion supra Section III.B.3

238. Sep Jolin HaR't Ely, Dlmocracy and Distrulst: A Tillory of JUdicial Rliviliw 149-53 (1980) (developing representation-reinforcement theory of judicial review); see also United States v. Carolene Prods. Co., 304 U.S. 144, 152 n.4 (1938) (describing contexts in which heightened judicial review may be appropriate).

239. See McDonald, 561 U.S. at $789-90$ (asserting that Second Amendment "protects the rights of minorities"); id. at $844^{-52}$ (Thomas, J., concurring) (discussing slavery, race, and gun control).

24\%. See Kim Parker, Juliana Menasce Horowitz, Ruth Igielnik, J. Baxter Oliphant \& Anna Brown, The Demographics of Cun Ounership, Piw Rscil. CIR. (June 22, 2017), https:// www.pewsocialtrends.org/2017/06/22/the-demographics-of-gun-ownership [https://perma.cc/

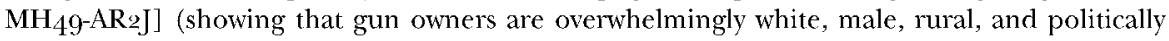
conservative).

241. See Cramer, supra note 159 , at 23 ("Racism is so intimately tied to the history of gun control in America that we should ... require that the courts use the same demanding standards when reviewing the constitutionality of a gun control law that they use with respect to a law that discriminates based on race.").

24\%. For a sampling of "second-class" claims in briefs and court opinions, see, for example, Amicus Curiae Brief of Nat'l Rifle Ass'n of Am. in Support of Petitioner at 22, Walker v. United States, 136 S. Ct. $23^{8} 7$ (2016) (No. 15-1027) ("The rights secured by the Second Amendment are not second-class rights, and this Court should grant certiorari to ensure that they are not relegated to that disfavored status."); Petitioners' Reply Brief at 2, Bonidy v. U.S. Postal Serv., $13^{6}$ S. Ct. 1486 (2016) (No. 15-746) ("This Court's review is further warranted because the deferential form of intermediate scrutiny applied by the panel majority below is inconsistent with this Court's precedents regarding how infringements on fundamental rights are analyzed and demonstrates how the lower courts are turning the Second Amendment into a second-class right."); and Peruta v. County of San Diego, 824 F.3d 919, 945 (9th Cir. 2016) (en banc) (Callahan, J., dissenting) ("The Second Amendment is not a 'second-class' constitutional guarantee.").

243. See infra notes $316-23$ and accompanying text 
of the civil rights framework, as indicated by landmark laws such as the Civil Rights Act of $1964 .{ }^{244}$ The strategy is to convince legislatures to use their authority to grant statutory protections to those who carry, use, or sell firearms, again on the ground that they are oppressed and politically powerless.

Finally, the civil rights or discrimination framing of the Second Amendment makes implicit and indeed often explicit appeals to AfricanAmericans, whose support for gun rights rests at levels well below that of whites and particularly white males. ${ }^{2}+5$ Thus, part of advocates' agenda may be to "market" the Second Amendment to particular groups that do not currently support broad interpretations of the right to keep and bear arms..$^{24^{6}}$

In sum, the civil rights frame seeks to associate arms advocates with a popular equality movement, cast doubt on the legitimacy of all gun control measures, lead to more aggressive forms of judicial review on behalf of gun owners, facilitate affirmative rights, and increase minority support for gun rights.

\section{E. CIVIL RIGITTS RIIETORIC VERSUS REALITY}

There is a long and well-documented historical intersection between race and the right to keep and bear arms. ${ }^{247}$ However, that history is more nuanced and complex than the civil rights frame suggests. ${ }^{9} 4^{8}$ In the end, accuracy may matter less to those who make such claims than the agenda items the claims serve, as discussed above, ${ }^{249}$ or their effects on public discourse and judicial rulings on the Second Amendment. However, it is still important that we critically analyze the central components of the civil rights narrative. What follows is not a detailed or point-by-point refutation, but rather a more general effort to separate rhetoric from reality.

\section{Discrimination and Gun Control}

The civil rights story frames the Second Amendment as an equality provision, one especially concerned with discrimination against AfricanAmericans and other oppressed groups. As we have seen, over time advocates have transformed this framing from a factual recitation of historical racebased disarmament (the "dark past") into an argument that "gun control is

\footnotetext{
244. Civil Rights Act of 1964 , Pub. L. No. 88-952, 78 Stat. 241 (codified at 42 U.S.C. $\$ 2000$ (2018)).

245. See Parker et al., supra note 240.

246. See Siegel, The Righl's Reasms, supra note 66, at 1672 (observing that the womanprotective abortion narrative "offered a framework for arguing with those outside the ranks of the antiabortion movement").

247. See Biocillis \& Millier, supra note 34, at 35 ("What cannot be gainsaid is that the histories of guns and race in the United States are inextricable.").

248. See id. (" $[\mathrm{T}]$ he relationship between guns and race is more nuanced than it might seem.").

249. Seediscussion supra Section III.D.
} 
racist." ${ }_{25}{ }^{\circ}$ One cannot deny the sordid history of race-based disarmament in America. This is part of the American "civil rights" narrative. However, aggressive forms of the civil rights frame, in particular those that link all current gun control measures to Jim Crow and otherwise seek to taint gun regulations with reference to segregation and racial oppression, exaggerate and over-claim.

One glaringly obvious problem with the "gun control is racist" argument is that even many early gun control measures had nothing to do with disarming slaves or freedmen. ${ }^{2} 5^{1}$ As scholars and jurists have observed, American history demonstrates that gun control measures of many varieties were actually common in the antebellum and postbellum eras..$^{2} 5^{2}$ Most of these measures were general in nature-for example, bans on concealed carry or restrictions on arms in certain populated places-and thus not racially tinged. ${ }^{253}$ Of course, these laws could be and sometimes were discriminatorily enforced. ${ }^{251}$ Moreover, some antebellum gun laws discriminated against immigrants and still others disparately affected the poor.255 Again, however, most such laws did not target particular classes of politically powerless individuals. ${ }^{25}{ }^{6}$ Rather, states and localities largely enacted them to further general public safety purposes. ${ }^{25 t}$

The brush of the "gun control is racist" argument paints too broadly in other respects. For example, the racist history of gun control does not support the conclusion that all historical successors, including the Brady Handgun Act, the federal ban on assault weapons, current "red flag" laws, or any other measure that neutrally regulates access to arms, violate equality rights. As Adam Winkler has observed, "In the twentieth century, gun control laws were often enacted after blacks with guns came to be perceived as a threat to whites." ${ }_{25}^{8}$ However, that fact does not generally taint modern gun control

\footnotetext{
250. See discussion supra Sections III.B.2-.9.

251. See, e.g., Adam Winkler, Gun Control is 'Racist'? The NRA Would Know, New Republici (Feb. 4, 2013) [hereinafter Winkler, Gun Control is 'Racist'?], https://newrepublic.com/article/ 112322 /gun-control-racist [https://perma.cc/6WPg-QAE9].

252. See, e.g., McDonald v. City of Chicago, 561 U.S. 742, 899-901 (2010) (Stevens, J., dissenting) (reviewing the history of early gun control laws); BLOCHER \& MILLER, supra note 34 , at 19-21 (discussing colonial era gun regulations); WINKI liR, supra note 127 , at 12 (noting that gun rights and gun control "have lived together since the birth of America").

253. See Winkler, Gun Control is 'Racist', supra note 251 ("Of course, not every gun law in American history was motivated by racism. In fact, some of our earliest gun laws had nothing to do with prejudice.").

254. See id.

255. See, e.g., Pratheepan Gulasekaram, Aliens with Guns: Equal Protection, Federal Power, and the Second Amendment, 92 IOWA L. REv. 891, 894-96, 903-04 (2007).

$25^{6}$. See Winkler, Gun Control is 'Racisl'?, supra note $25^{1 .}$

257. See id.

$25^{8}$. WINKLER, supra note 127 , at $\mathrm{x}$.
} 
measures with the stain of the Black Codes and other historically race-based disarmaments.

The "ugly history" argument also proves too much as a matter of simple logic. Early laws of an infinite variety discriminated against African-Americans and other racial and ethnic minorities. For example, free speech rights were not "free" for everyone. ${ }^{259}$ During and even after Jim Crow, African-Americans did not have equal property, voting, or marriage rights. ${ }^{260}$ However, that does not mean today we ought to treat all laws regulating speech, marriage, property, voting, or other rights as inherently suspect owing to their racist histories. Instead, when evaluating these contemporary laws, we recognize the changes brought about by law, including major civil rights enactments and alterations of constitutional equality doctrines. ${ }^{261}$

In sum, the right to keep and bear arms was one of a great many rights African-Americans and other marginalized persons did not enjoy in equal measure with their white neighbors. Leaping from that history to "gun control is racist" deploys a logic that would condemn nearly all laws on the same ground. ${ }^{262}$

\section{Arms and Civil Rights}

The part of the civil rights narrative that seeks to connect arms possession to African-American safety and survival is also more complicated than advocates often suggest. It is true that some slaves and freedmen armed themselves to resist official and private bondage and violence. ${ }^{263}$ It is also true that they suffered horrendous consequences for acts of armed rebellion. ${ }^{264}$ Heroic stories often leave out the aftermath, in which armed white vigilantes lynched armed African-Americans simply because they took up arms, or the fact that having access to arms turned out to be futile in the fight against slavery. ${ }^{265}$ The notion that arming African-Americans would have led directly to the defeat of Jim Crow and the deeply embedded system of southern segregation is at best historically questionable.

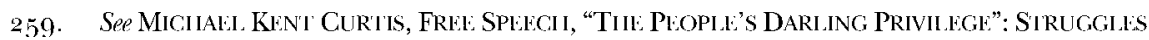
FOR FRLILOOM OF EXPRISSION IN AMLRICAN HISIORY $300-56$ (2000) (discussing restrictions on abolitionist speech during the Civil War).

260. See Loving v. Virginia, 388 U.S. 1, 11-12 (1967) (invalidating Virginia's ban on interracial marriage).

261. Not all are willing to trust wholly in such changes. See Johnson, supra note 187 , at 1506 ("A cumulative assessment of Black distrust of the state undercuts modern claims that the tradition of distrust is no longer salient because things have changed.").

262. Winkler, Gun Control 1s 'Racist'?, supra note 251.

263. See BioCilir \& Mil.uir, supra note 34, at 37 (discussing examples of Nat Turner and John Brown).

264. See id. at $38-39$ (noting the bloodshed that followed Brown's rebellion, and his hanging); WINKLER, supra note 127, at 191-32 (describing disproportionate deaths of freed slaves in the Nat Turner rebellion, and the subsequent hardening of racial disarmament).

$26_{5}$. Everitt, supra note 175 .
} 
A similar narrative has taken hold with respect to the civil rights movement of the 195 os and $19605 .{ }^{266}$ The story crediting the Deacons and other armed civil rights activists with the successes of the civil rights movement is ahistorical. There are several notable gaps in this narrative.

For one thing, the Deacons did not organize until well after Brown $v$. Board of Education and other seminal events of the movement had already occurred. In fact, the group formed in the mid-196os, around the time President Johnson signed the landmark Civil Rights Act of $196_{4}$ into law. ${ }^{267}$ Yet according to one part of the civil rights narrative, this then-little-known group of armed activists was responsible for the success of a civil rights movement whose most notable public acts demonstrated members' commitment to non-violence. ${ }^{268}$ To be sure, there were pockets of armed resistance in the civil rights movement, and many African-Americans supported and indeed exercised rights of armed self-defense. ${ }^{.69}$ The Deacons and other armed civil rights activists likely prevented some Klan, vigilante, and other forms of violence. ${ }^{20}$ However, most of the stories of armed civil rights activism seem to rest on a narrative of potential deterrence rather than demonstrated acts of self-defense. We ought not to discount the value of such deterrence, but we also ought not to overstate the role firearms played in civil rights history.

A related but more general claim of the civil rights frame is that access to firearms played a significant role in whatever successes civil rights organizations achieved during the race equality movement. ${ }^{271}$ Dr. King was surely aware of the history of violent rebellion in pre-and antebellum America and supported the right to defend one's home and family with arms. ${ }^{272}$ While he respected the contribution of armed resistance to racial equality and appreciated that arms were useful to self-defense, the movement Dr. King led explicitly rejected armed resistance as too costly in terms of lives and principles. ${ }^{273}$

King's rejection of armed rebellion and other forms of violence as ways to make progress on civil rights led to the rise of more militant leaders and groups, including Malcolm X and the Black Panthers. ${ }^{271}$ Thus, not all involved in the civil rights movement disclaimed armed self-defense as a tactic. Indeed, Malcolm X explicitly called for arming African-Americans as a means of

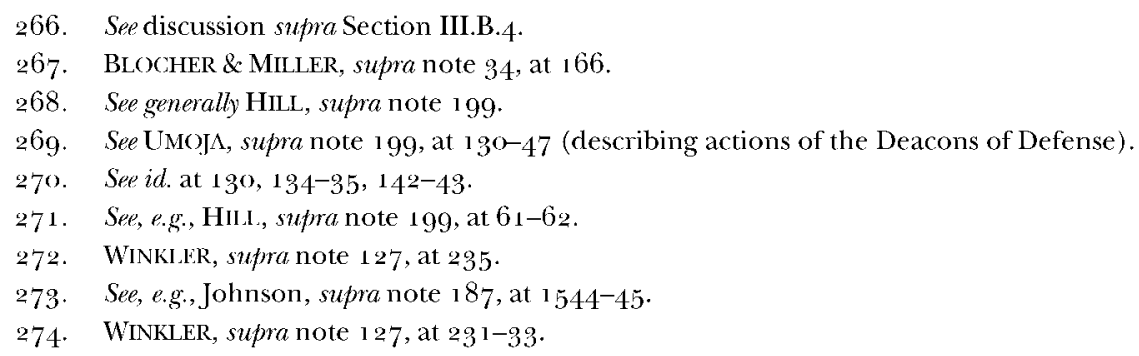


resisting despotic governments and achieving racial equality. ${ }^{975}$ However, these pockets of armed resistance do not demonstrate that the civil rights movement generally embraced arms as a means of facilitating civil rights, or that the possession of firearms contributed to its success.

Other aspects of the civil rights frame as it relates to the movement are more cynical and nakedly rhetorical. This includes comparing modern-day gun regulations to Jim Crow-era laws, including poll taxes and literacy tests. ${ }^{27}$ These analogies ignore the indignities and burdens such measures purposefully inflicted on African-Americans, who, unlike the vast majority of gun owners, are indeed the type of "discrete and insular minorities" the Constitution's equality provisions protect. ${ }^{277}$ One cannot plausibly compare measures intended to deny fundamental rights to and jeopardize the lives of AfricanAmericans to laws that may make it more burdensome for every person to purchase, keep, or bear arms. The rhetoric of some gun rights advocates, some of which relies on comparisons between race discrimination and gun discrimination, is hard to take as anything more than pure sophistry. ${ }^{278}$

Even the NRA's own civil rights branding is misleading. The NRA is not, as its leaders have repeatedly claimed, the "oldest civil rights organization in America." 279 That honor belongs to the National Association of the Deaf, founded in $1880 .{ }^{280}$ When the NRA was founded in 1871 , its purpose "was to "promote and encourage rifle shooting on a scientific basis." " 81 The NRA did not even begin to lobby on behalf of gun rights until the 1930s. ${ }^{282}$ Additionally, the National Association for the Advancement for Colored People, founded in 1909, has been advocating for racial equality and civil rights far longer than the NRA. ${ }^{28} 3$

275. See BLOCHER \& MILLER, supra note 94, at 166-67 (recounting history).

276. See sources cited supra notes 181-82; see also J. Baxter Stegall, Comment, The Curse of IIam: Disarmament Through Discrimination-The Necessity of Applying Strict Scrutiny to Second Amendment Issues in Order to Prevent Racial Discrimination by States and Localities Through Gun Control Laws, 11 LIBERTY U. L. REV. 271, 306-08 (2016) (relying on the heavy shadow of discrimination from past gun control measures, so-called "motive" evidence, alleged similarities between gun control laws, poll taxes and literacy tests, and disparate impact on racial minorities).

277. See United States v. Carolene Prods. Co., 304 U.S. $144,15^{2}$ n.4 (1938) (indicating that stricter forms of judicial scrutiny apply to classifications that burden "discrete and insular minorities" who lack political forms of redress).

278. See Dimiero, supra note 184 (quoting former NRA president Marion Hammer as comparing proposed assault weapons ban to discrimination based on " $t \mathrm{t}]$ he color of a gun").

279. See Morrison, supra note 179 .

280. Oldest Cizil Righls Organizalion in the U.S., NAl'L Ass'N Dliaf, https://www.nad.org/ oldest-civil-rights-organization-in-the-us [https://perma.cc/4TFX-7 $\left.\mathrm{BP}_{3}\right]$.

281. WINKLER, supra note 127 , at 63 .

282. Cydney Hargis, No, the NRA is Not Actually the United States' "Oldest Civil Rights Organization,"SALON (May 7, 201 7, 1:58 PM), https://www.salon.com/201 7/05/07/no-the-nrais-not-actually-the-united-states-oldest-civil-rights-organization [https://perma.cc/7BTJ-32LW].

283. Id. 
The overstating is emblematic of many aspects of the civil rights narrative. The equality frame leaps from dark historical reality to contemporary contexts as if nothing has changed in the interim. Again, an unfortunate part of gun rights history in the United States has been the discriminatory disarming of African-Americans. ${ }^{28}$. That history understandably makes some wary of proposals that African-Americans and other marginalized individuals can place their faith in the state. It should make us all sensitive to the harms of purposeful discriminatory disarmament. However, history does not support the argument that "all gun control is racist."

Finally, in terms of the civil rights narrative we ought to give due consideration to the disparate treatment of African-Americans and other marginalized persons when it comes to state-sanctioned violence. Some argue that as currently enforced and exercised, the Second Amendment primarily protects white males. ${ }^{285}$ Armed or unarmed, black men, in particular, are especially vulnerable to police violence. ${ }^{286}$ At the very least, the civil rights narrative must come to terms with the intersectionality of gun violence, which highlights the disparate impact of gun violence on African-Americans, women, and LGBTQ persons. ${ }^{287}$

\section{Gun Rights as Equality Rights}

As previously noted, one of the agenda items associated with the Second Amendment's civil rights framing is heightened protection for gun owners under an equality framework. ${ }^{288}$ Another is to encourage legislatures to enact affirmative anti-discrimination and other gun rights protections. ${ }^{289}$

Civil rights gun rhetoric runs into difficulties when advocates seek to translate it into legal and constitutional claims. Current equal protection doctrine cuts sharply against judicial treatment of gun control laws as suspect. Laws that do not target or expressly discriminate on racial or other suspect grounds do not receive heightened judicial scrutiny under the Fourteenth Amendment's Equal Protection Clause or the Fifth Amendment's Due Process Clause. ${ }^{290}$ Thus, to make out such a claim, those who challenge

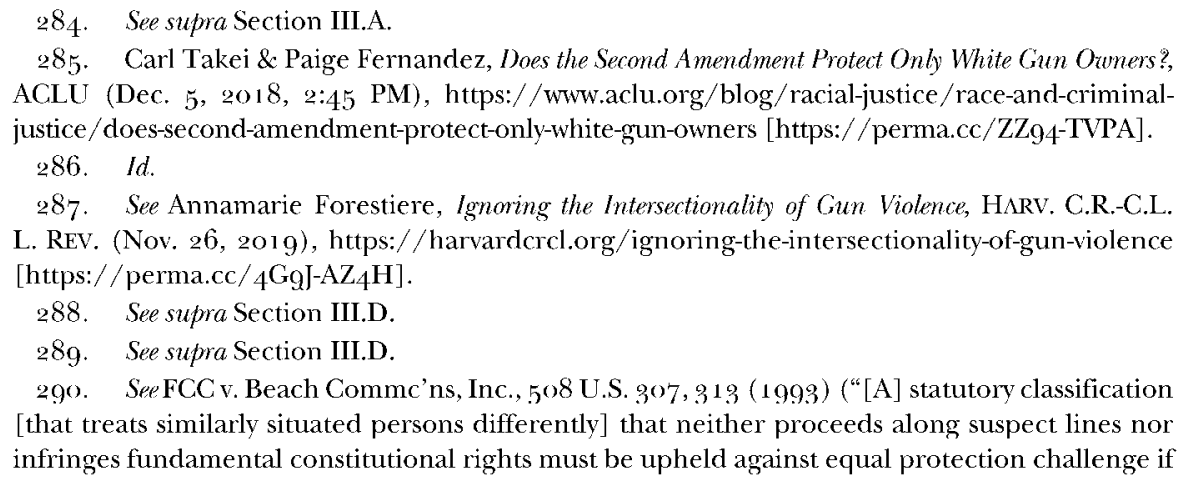

285. Carl Takei \& Paige Fernandez, Does the Second Amendment Protect Only White Gun Ovwers?, ACLU (Dec. 5, 2018, 2:45 PM), https:/ www.aclu.org/blog/racial-justice/race-and-criminaljustice/does-second-amendment-protect-only-white-gun-owners [https://perma.cc/ZZ94-TVPA]. 
gun control laws must demonstrate purposeful discrimination.91 Since they generally cannot make this showing, advocates usually rely on "disparate impact" arguments and the claim that because somegun laws in the eighteenth and nineteenth centuries were racially or otherwise discriminatory, courts must treat all modern gun laws this way. ${ }^{292}$ Current equal protection doctrine does not support these sorts of equality-based arguments. ${ }^{293}$

Relatedly, gun control opponents have sought to characterize gun owners and gun rights advocates as politically powerless minorities. Among other things, gun rights advocates have invoked the specters of Jim Crow, Nazism, immigration xenophobia, gender discrimination, and LGBTQ discrimination to shore up their equal protection bona fides. ${ }^{294}$ Again, however, the reality is that most gun owners in the United States are white males. ${ }^{295}$ This fact, along with the reality that modern gun control laws do not discriminate based on race or any other suspect characteristic, significantly undermines gun owners' equal protection claims.

Indeed, scholars have pointed out the inherent weaknesses of the socalled "political process" theory as a justification for heightened judicial scrutiny of gun control measures. ${ }^{296}$ As noted, that approach pegs the degree of judicial scrutiny for laws regulating constitutional rights in part to their effect on "discrete and insular minorities"-in essence, classes of persons who are politically powerless. ${ }^{297}$ As Professor Cass Sunstein has observed, " $[t]$ here is no special reason for an aggressive judicial role in protecting against gun control, in light of the fact that opponents of such control have considerable political power and do not seem to be at a systematic disadvantage in the democratic process." ${ }^{298}$ Indeed, there is considerable evidence that gun owners exercise significant political power. ${ }^{299}$ Among other things, state and federal legislation expanding gun rights well beyond the scope apparently recognized in Heller and McDonald, strongly suggests that gun owners enjoy

there is any reasonably conceivable state of facts that could provide a rational basis for the classification." (citation omitted)).

291. See Washington v. Davis, 426 U.S. 229, 240 (1976) (requiring plaintiffs to show purposeful discrimination under the Equal Protection Clause).

292. See Stegall, supra note 276 , at $306-08$ (2016) (relying on the heavy shadow of discrimination from past gun control measures, so-called "motive" evidence, alleged similarities between gun control laws, poll taxes and literacy tests, and disparate impact on racial minorities).

293. See Beach Commc'ns, Inc., 508 U.S. at 313 (generally requiring that law expressly discriminate based on race for heightened scrutiny to apply).

294. See BLOCHER \& MILLER, supra note 94, at 188 n.89.

295. Sep sources cited supra notes 161, 240 .

296. For the seminal account of the political process theory, see generally JOIN HART EIY, DLMOCRACY AND DisIRUSI (1980) (laying out the political process theory).

297. United States v. Carolene Prods. Co., 304 U.S. $144,15^{2}$ n.4 (1938).

298. Cass R. Sunstein, Second Amendment Minimalism: Heller as Griswold, 122 HARV. L. REv. 246,260 (2008); see also BLOCHER \& MILLER, supra note 34, at 187 (discussing political process theory as it relates to the Second Amendment).

299. BLOCHER \& MILLER, supra note 34, at 189-9o. 
considerable political power despite their numbers.300 Moreover, one of the reasons courts apply heightened scrutiny to race-based and other suspect classifications is because the trait used for classification is immutable. $3^{01}$ However, there is nothing immutable about keeping and bearing arms-these acts are the product of individual choice rather than immutable trait.

Notwithstanding all this, in his McDonald concurrence, Justice Thomas claimed that the racialized history of the Second Amendment and the contemporary fact of urban violence affecting the safety of African-Americans showed that the Second Amendment does indeed protect "discrete and insular minorities." ${ }^{902}$ The implication, again, is that all gun control laws ought to be subject to heightened scrutiny, which may well be Justice Thomas' position. However, as he surely knows, under current equal protection doctrine only laws that single out politically powerless minorities are so treated. $3^{\circ}$ Since modern gun control laws are facially race-neutral, the civil rights "political process" argument does not establish a basis for heightened scrutiny.

Although the political process argument is not a winner, there may be other equality-based concerns with gun control measures. For example, litigants have challenged on equal protection and other grounds measures that prohibit sales based on age, mental illness, alienage, type of felony, type of arms, the charging of different fees based on gun ownership, non-resident status, and other grounds. ${ }^{04}$ For the reasons discussed, including the lack of discrimination on any "suspect" ground, the vast majority of those claims have so far failed..$^{0_{5}}$ Commentators have also presented research relating to the

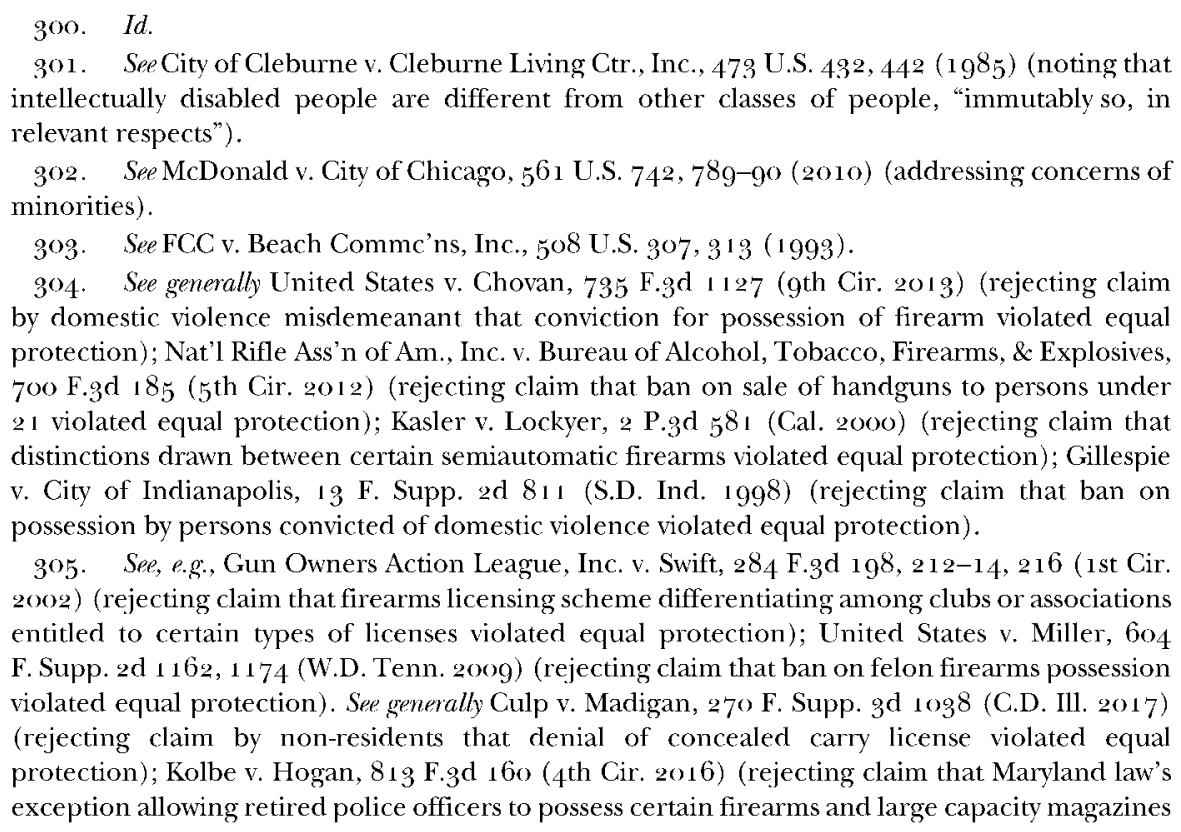
protection); Nat'l Rifle Ass'n of Am., Inc. v. Bureau of Alcohol, Tobacco, Firearms, \& Explosives,

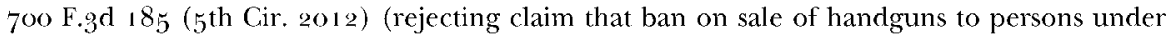
21 violated equal protection); Kasler v. Lockyer, 2 P.9d 581 (Cal. 2000) (rejecting claim that distinctions drawn between certain semiautomatic firearms violated equal protection); Gillespie v. City of Indianapolis, 13 F. Supp. 2d 811 (S.D. Ind. 1998) (rejecting claim that ban on possession by persons convicted of domestic violence violated equal protection).

305. Sep, e.g., Gun Owners Action League, Inc. v. Swift, 284 F.3d 198, 212-14, 216 (1st Cir. 2002 ) (rejecting claim that firearms licensing scheme differentiating among clubs or associations entitled to certain types of licenses violated equal protection); United States v. Miller, $60_{4}$ F. Supp. 2 d 1 162, 1174 (W.D. Tenn. 2009) (rejecting claim that ban on felon firearms possession violated equal protection). See generally Culp v. Madigan, 270 F. Supp. 3 d 1098 (C.D. Ill. 2017) (rejecting claim by non-residents that denial of concealed carry license violated equal protection); Kolbe v. Hogan, 813 F.3d 160 (4th Cir. 2016) (rejecting claim that Maryland law's exception allowing retired police officers to possess certain firearms and large capacity magazines 
disparate economic effects of certain arms regulations. $3^{\circ 6}$ Under current equal protection doctrine, however, courts do not consider wealth classifications "suspect" or "quasi-suspect." $3^{\circ} 7$ Thus, in order to survive judicial scrutiny, these measures must only be rationally related to legitimate government interests. $3^{08}$

Gun rights advocates are likely to continue pressing courts to rule on equality claims, if only in part to emphasize the connection between gun rights and equality. ${ }^{\circ 09}$ They can challenge the rationality of gun control classifications, including on grounds that legislators acted out of "animus" toward gun owners or for other irrational reasons, or on grounds that law enforcement officials applied neutral laws in a discriminatory manner.310

Even if these claims are not likely to succeed, they will impress on courts the importance of ensuring that legislative bias against those who possess arms does not infect gun control law. Framing gun regulations as a threat to equality might convince some courts to take a closer look at the challenged measures.311 Further, challengers will likely also continue to challenge the disparate impact of some gun control laws and policies. For example, plaintiffs successfully argued that New York City's "stop and frisk" policy targeted African-American males. ${ }^{12}$ In short, there is an equality dimension to gun control. However, that dimension is far narrower than the civil rights narrative suggests.

violated equal protection); People v. Brown, 173 Cal. Rptr. gd 812 (Ct. App. 2014) (rejecting claim that ban on sale of "Saturday Night Specials" violated equal protection); Kwong v. Bloomberg, 723 F.gd 160 (2d Cir. 2013) (rejecting argument that provision allowing city and county to set licensing fee higher than state fee violated equal protection); United States $\mathrm{v}$. Carpio-Leon, 701 F.3d 974 (4th Cir. 2012) (rejecting claim that law prohibiting possession of firearms by those in the United States illegally violated equal protection); Silveira v. Lockyer, 312 F.3d $105^{2}$ ( $9^{\text {th }}$ Cir. 2002) (rejecting claim that exception allowing active peace officers to possess assault weapons violated equal protection, but finding no rational basis for allowing retired peace officers to possess assault weapons).

3o6. See generally, e.g., T. Markus Funk, Comment, Cun Control and Economic Discrimination: The Melting-Point Case-in-Point, 85 J. CRIM. L. \& CRIMINology 764 (1995) (arguing that restrictions on the purchase of certain types of firearms have a disparate economic impact).

307. See, e.g., City of Cleburne v. Cleburne Living Ctr., 473 U.S. $43^{2}, 445^{-4} 4^{6}$ ( 1985 ) (mental disability); Mass. Bd. of Retirement v. Murgia, 427 U.S. 307,313 (1976) (age); James v. Valtierra, 402 U.S. 137,141 (1971) (wealth).

308. Beach Comme'ns, Inc., 508 U.S. at 313 .

309. See sources cited supra note 305. See generally Gulasekaram, supra note 255 (analyzing state and federal authority to limit possession of firearms by aliens).

310. See Romer v. Evans, 517 U.S. 620, 692 (1996) (explaining that the law was "inexplicable by anything but animus toward the class it affects").

311. Already, a few equality claims have succeeded. See generally Perros v. County of Nassau, $23^{8}$ F. Supp. 3d 395 (E.D.N.Y. 2017) (allowing disabled retired officers' (who had been denied permission to possess firearms after their retirement) equal protection claim to proceed); Fotoudis v. City of Honolulu, 54 F. Supp. 3d $113^{6}$ (D. Haw. 2014) (holding that the law banning lawful permanent residents from obtaining firearms permits violated equal protection).

312. See Floyd v. City of New York, 959 F. Supp. 2d 540, 56o (S.D.N.Y. 2013) (finding discriminatory enforcement by police of "stop and frisk" policies in New York City). 
Courts as well as legislatures protect equality-based civil rights. Indeed, one of the distinctive aspects of modern-day "civil rights" is the role governments play in affirmatively protecting such rights. ${ }^{313}$ As we will see, the libertarian framing of the Second Amendment objects to all governmental intervention in the area of arms. ${ }^{31}$ By contrast, the civil rights agenda welcomes and seeks state intervention on behalf of gun rights. ${ }^{315}$

Under the Equal Protection Clause, equality rights are negative in the sense that they prohibit certain governmental actions. However, statutory and administrative protections, including public accommodations and antidiscrimination laws, protect equality as a positive right. Gun rights proponents have achieved a significant measure of legislative civil rights protection. State and federal legislatures have enacted a number of laws to protect gun owners from different kinds of allegedly discriminatory treatment. For instance, 11 states currently limit private businesses' authority to exclude individuals carrying firearms from their premises. ${ }^{3{ }^{16}}$ Moreover, more than 4 o states have enacted laws preempting the power of localities to enact gun control ordinances. ${ }^{317}$ These laws prevent localities from singling out firearms or firearms owners for special restrictions. Florida law once restricted physicians from asking patients about gun ownership, unless such questions related to a specific course of treatment. ${ }^{318}$ Federal and state lawmakers have proposed or enacted laws that prohibit banks from discriminating against businesses that sell firearms. ${ }^{319}$ In addition, potential gun purchasers have relied on general anti-discrimination laws to challenge age and other restrictions on firearms sales. ${ }^{200}$

Gun rights advocates have also sought to imitate or borrow other aspects of existing civil rights regimes. For example, in some states local sheriffs have asserted that, with regard to state gun control laws, their jurisdictions are "sanctuary count[ies]," which means that local sheriffs will refuse to enforce state laws regulating access to firearms.321 The policies openly mimic the

\footnotetext{
313. Sep infra notes $316-23$ and accompanying text.

314. See infra Part IV.

315. See supra Section III.D.

316. See BLOCHER \& Miller, supra note 94, at 190 n.104 (listing state laws).

317. Id. at 189 .

318. Sep generally Wollschlaeger v. Governor of Fla., 848 F.gd 1293 (1 1 th Cir. 2017) (en banc) (holding law violated First Amendment).

319. See, e.g., Lisa Marie Pane, Corporate America Taking New Steps to Cuntail Sales of Firearms, CHI. TRIB. (June 24, 2018, 4:12 PM), https://www.chicagotribune.com/business/ct-corporateamerica-guns-20180624-story.html.

320. See, e.g., Polly Mosendz, Blocking Cun Sales to Buyers Under 2 I Might Be Illegal, BLOOMBERG; (Mar. 9, 2018, 6:00 AM), https://www.bloomberg.com/news/articles/2018-og-og/blockinggun-sales-to-buyers-under-the-age-of-2 1-might-be-illegal [https://perma.cc/KEU2-38L4].

321. See J.D. Tuccille, Popular Defiance Will Kneecap Gun Laus in New Mexico, As II Has in Other Siales, RlASON (Mar. 4, 2019, 12:00 PM), https://reason.com/2019/03/04/defiance-will-
} 
decision by some progressive localities not to assist the federal government in its enforcement of immigration law. 322

These affirmative protections are obviously important to gun owners. However, as Second Amendment scholars have noted, they also tend

to dispel the notion that the right to keep and bear arms is vulnerable to the kind of broad political process failures that justify aggressive judicial enforcement in other constitutional areas or on behalf of other groups. In fact, they underline the notion that the political process is working for the benefit of gun owners well beyond what Heller requires. 323

\section{The SECONd Amendment's Civil LiBerties Frame}

Gun rights advocates have also framed the Second Amendment as one of the Constitution's inalienable "civil liberties." This framing, which primarily grounds the Second Amendment in autonomy rather than equality concerns, has likewise evolved over time. In its more moderate iteration, gun rights advocates have relied on well-worn libertarian themes and analogies to other constitutional liberties. ${ }^{321}$ In more extreme forms, the civil liberties frame has increasingly relied on fears about governmental disarmament and despotism.325 Over time, according to this narrative, the Second Amendment has become an absolute guarantee, impervious to the needs and interests of civil society. 326

\section{A. THL NATURL OI "CIVIL LIBIRTY"}

As discussed earlier, meanings and understandings of "civil right" and "civil liberty" have evolved over time.927 Prior to the 1940s, commentators and others often used these phrases interchangeably when referring to constitutional and statutory rights; however, by the second half of the twentieth century, a commonly accepted distinction had developed between the concepts. 328

\footnotetext{
kneecap-new-mexico-gun-law [https://perma.cc/938Y-GRJ2] (reporting on sanctuary counties in New Mexico and several other states).

322. See Hiroshi Motomura, Arguing About Sanctuary, 52 U.C. DAVIS L. REV. 435, 447-48 (2018). 323. BLOCHER \& MILLER, supra note 34, at 191.

324. See, e.g., Petitioners' Reply Brief at 2, Bonidy v. U.S. Postal Serv., $13^{6}$ S. Ct. 1486 (2016) (No. 15-746) ("This Court's review is further warranted because the deferential form of intermediate scrutiny applied by the panel majority below is inconsistent with this Court's precedents regarding how infringements on fundamental rights are analyzed and demonstrates how the lower courts are turning the Second Amendment into a second-class right.").

325. See discussion infra Section IV.B.2.

326. See discussion infra Section IV.B.2.

327. See discussion supra Section III.A.

328. See Schmidt, supra note 17 , at 8 (observing that "[a]ctivists and observers used the two labels interchangeably to describe the campaign to expand workers' rights in the opening decades of the twentieth century").
} 
I am principally interested in deployment of the modern conception of civil liberty, which generally refers to "the political freedom that is enjoyed by members of society that restrains its people as far as is necessary to maintain the general welfare of everyone."329 However, as modern civil libertarians, including gun rights advocates, often ground their arguments in the history of inalienable rights and the principles of the founding and pre-founding eras, ${ }^{33^{\circ}}$ we must also be familiar with historic conceptions of civil liberty.

Although there is not space here to trace the concept to its origins and recount the history in detail, we can construct a rough sketch of civil liberty. One could obviously consult many sources, including John Milton and John Stuart Mill. However, there may be no better authority than Sir William Blackstone, who expounded on civil liberty in his Commentaries on the Laws of England, a treatise widely read during the pre-founding and founding eras.391

Blackstone generally categorized rights as either being "absolute" or "relative." $33^{2}$ Without going too deeply into the details, Blackstone concluded that there were few "absolute" rights. 333 . Hence, he conceived of most rights as circumscribed to some degree by the needs of society. 331 In general, absolute rights were natural rights that owed their existence to the "immutable laws of nature," while "civil liberties" were the relative rights of individuals, "incident to them as members of society, and standing in various relations to each other." "335 Hence, for example, the maintenance and protection of the "absolute" right of personal security was possible only through the regulation of aspects of this right in light of the safety and security of other members of society. .936

As Blackstone explained, every person who enters society "gives up a part of his natural liberty, as the price of so valuable a purchase; and ... obliges himself to conform to those laws, which the community has thought proper to establish." 337 He contrasted this form of liberty with "that wild and savage liberty which is sacrificed to obtain it." ${ }_{33}^{8}$ As Blackstone explained, the consequence of absolute liberty "is, that every other man would also have the same power, and then there would be no security to individuals in any of the enjoyments of life." 339 Thus, he defined "civil liberty" as "no other than natural

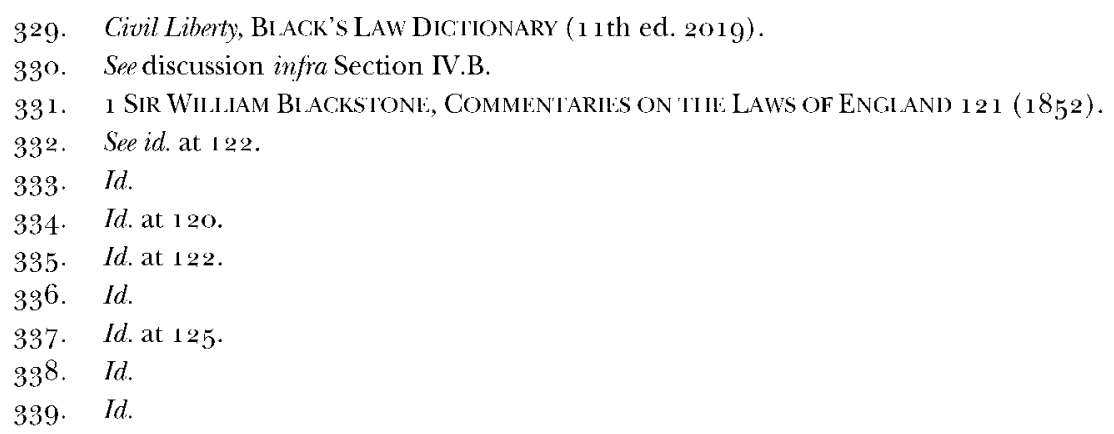


liberty so far restrained by human laws (and no farther) as is necessary and expedient for the general advantage of the public." $34^{\circ}$

Blackstone observed that when a law restrains an individual from "doing mischief to his fellow-citizens, though it diminishes the natural, increases the civil liberty of mankind." $31^{1}$ To be sure, he distinguished necessary restraints on liberty from "wanton and causeless" ones.312 However, Blackstone did not doubt that governments were empowered to regulate civil liberty so long as they had what he called "a good end in view." 313

This was true, in particular, of the right to keep and bear arms. Blackstone observed that the right of individuals "of having arms for their defence, suitable to their condition and degree, and as such as are allowed by law" was a right auxiliary to the absolute or natural right of personal security. ${ }^{344}$ It was "a public allowance under due restrictions, of the natural right of resistance and self-preservation, when the sanctions ... and laws are found insufficient to restrain the violence of oppression." 315 Thus, to vindicate their natural rights, the people were entitled to keep and bear arms for self-preservation and defense, "unless where the laws of our country have laid them under necessary restraints." ${ }_{1} 1^{6}$ As the Supreme Court observed in McDonald, another early influential commentator, St. George Tucker, "described the right to keep and bear arms as "the true palladium of liberty' and explained that" the principal concern was that outright prohibitions "would place liberty "on the brink of destruction." "s47

Although today we tend not to speak in such terms, early commentators understood the traditional conception of civil liberty as informed by a distinction between "liberty" and "license." $34^{8}$ As the highlighted text shows, Blackstone and others conceived of the enjoyment of "civil liberty" as 
circumscribed by law-subject to "due restrictions" and limited by "necessary constraints." ${ }_{499}$ By contrast, commentators viewed "license" as the exercise of liberty without limitation and a dangerous form of anarchy. $35^{\circ}$ As we will see, the modern form of the Second Amendment civil liberty frame often disregards the distinction between "liberty" and "license." 351 Instead, today's civil liberty narrative frequently calls for an absolute liberty impervious to state regulation. $35^{2}$

\section{B. CONTEMPORARY CINI. LIBERTIES FRAMES}

In the modern era, the concept of "civil libert[y] is premised on skepticism toward government interference in the private sphere." 353 As Professor Schmidt has explained, "[a]utonomy rather than equality is the guiding principle of civil liberties." 351 Thus, unlike the Second Amendment civil rights frame, which welcomes government intervention designed to protect gun rights, the civil liberties frame rejects intervention by the state. Indeed, today's civil liberties frames are far more resistant to arms regulations than Blackstone and other early commentators.

\section{The Libertarian Second Amendment}

As recounted by Professor Siegel, "the birth of a libertarian movement for Second Amendment rights" was primarily the product of 1960 s political debates concerning federal gun control measures. 355 By the 1970 , resistance to gun control was rising on a number of fronts..$^{35}$ After the disruptive events of the 1960 s, conservatives started to question the NRA's stance on gun control. ${ }^{357}$ As Siegel observes, "[o] pposition to gun control was now expressed in law and order frames. ${ }^{35} 5^{8}$ Gun rights advocates supported an individual right to keep and bear arms for purposes of defending themselves and others against criminals and other lawless threats.359

The NRA and other gun control opponents "voiced a libertarian spirit that was increasingly hostile to the government in any guise." "960 At the same time, Ronald Reagan and other political figures began to communicate law

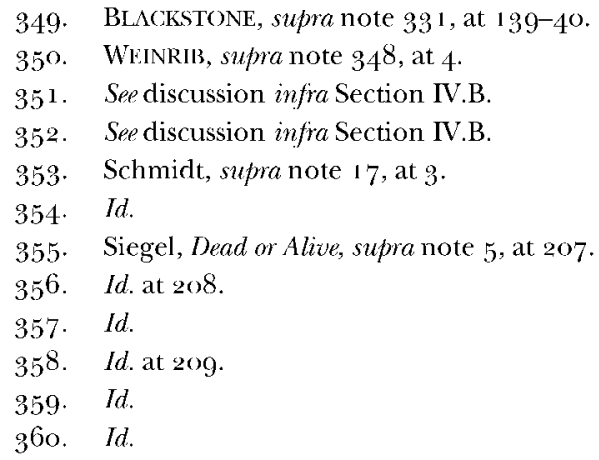


and order and libertarian gun rights claims "in a constitutional register." $3^{61}$ Among other things, they asserted that the Second Amendment's text plainly prohibited most if not all gun regulations. ${ }^{362}$ The appeal to text was combined with a strategy to "restore" the constitutional right to keep and bear arms by relying on the Amendment's "original understanding," which gun rights advocates argued included an individual right to keep and bear arms. $3^{63}$ Advocates deployed the vocabulary of "restoration" in part to encourage and justify active judicial review of gun control measures. ${ }^{36_{1}}$ Heller, which was the product of originalist methodologies, represented the crowning achievement of the libertarian framing of the Second Amendment.

The NRA did not always oppose reasonable limits on the right to keep and bear arms. ${ }^{36}{ }_{5}$ However, in response to the enactment of federal and state gun control laws and various other social and political influences, the organization changed its political orientation and its stance on gun regulations..$^{366}$ As Professor Siegel observed, "Decades of mobilization inside and outside the academy forged modes of interpreting the Second Amendment that make libertarian, law-and-order concerns central to its meaning and republican concerns peripheral." ${ }^{6}{ }^{6} 7$ By the early 1980 s, the Second Amendment's civil liberty framing had become highly individualistic and deeply skeptical of governmental regulation.

\section{Disarmament, Despotism, and Absolutism}

The modern Second Amendment civil liberties frame has shifted from concerns about individual self-defense, which of course remain important, to instilling in the public an apocalyptic fear of governmental disarmament and

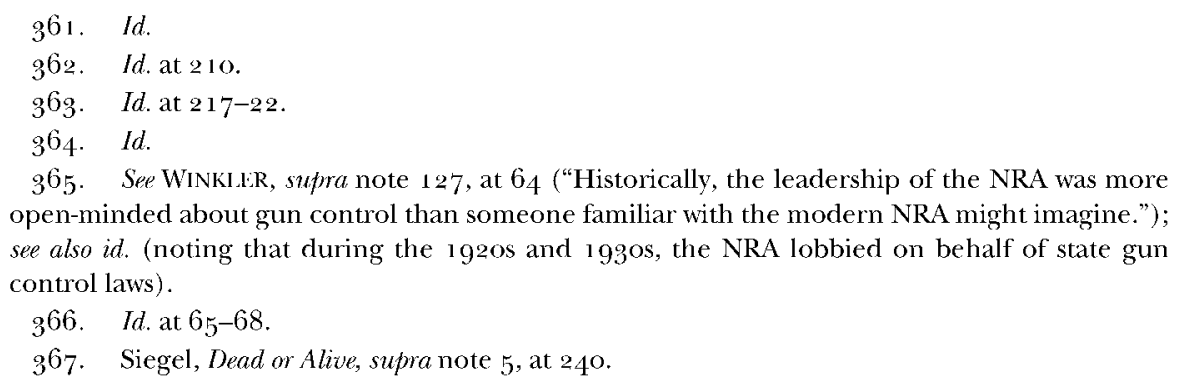
open-minded about gun control than someone familiar with the modern NRA might imagine."); see also id. (noting that during the 1920 s and 1990 s, the NRA lobbied on behalf of state gun control laws). 
despotism..$^{68}$ As an answer to this dystopian vision, gun rights advocates have proposed an absolutist conception of the Second Amendment. $3^{69}$

One of the central pillars of the modern civil liberty frame consists of dire warnings of arms confiscation. $37^{\circ}$ The disarmament narrative constructs a reality in which a combination of government officials and private actors are plotting to seize and confiscate the firearms of law-abiding individuals. 371 Although aspects of this narrative were in place as early as the $197^{\circ 0^{3}, 32}$ it exploded in the wake of highly publicized federal law enforcement actions against Randy Weaver, a white supremacist and survivalist in Idaho, and the ill-fated raid on the Branch Davidian compound in Waco, Texas.973 Thereafter, members of self-described "militias" publicly decried a purported conspiracy by the United Nations and other governmental institutions to disarm Americans. 374

The NRA aggressively promotes the disarmament frame in publications and speeches by its leaders. 375 It presents a narrative about the "destruction" of the Second Amendment and governmental plots to confiscate firearms.376 It warns gun rights supporters of a "Disarm America Movement" that "is the bestfunded, most sophisticated assault on our God-given liberties in American history." "ir in alarmist tones, leaders presage "an all-out assault on the sacred pillars of our heritage and way of life: our flag; our national anthem and our Second Amendment." ${ }_{37}^{8}$

If the avatar of the civil rights narrative is the (urban) African-American man or woman besieged by community gun violence and ineffective (or

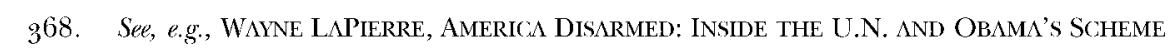
TO Destroy THE SECONd Amendment (2011); Marilyn Mayo, Mainstreaming Gun Confiscation Conspiracy Theories, ADL (Jan. 13, 2016), https://www.adl.org/blog/mainstreaming-gunconfiscation-conspiracy-theories [https://perma.cc/ADX 5 -TNYT]. See also generally RUKMANI BhutL, Guns, Lies, and FeAr: Exposing The NRA's Messaging PlayboOK (2019), https:// www.americanprogress.org/issues/guns-crime/reports/2019/04/24/468951/guns-lies-fear [https://perma.cc/H8]2-CERU] (examining the rise of the disarmament narrative in NRA speeches and publications).

369. See, e.g., Byron Berger, Why Every (Yes, Every) Gun Control Law Is Unconstitutional, OfF TIIl: GRII Niws, https://www.offthegridnews.com/self-defense/why-every-yes-every-gun-control-lawis-unconstitutional [https://perma.cc/GJT2-SYV 4 ].

37\%. See sources cited supra note 368 .

371. See sources cited supra note 368 .

372. See Siegel, Dead or Alize, supra note 5 , at 212-17 (discussing movement politics leading to libertarian frame).

373. See WINKLER, supra note 127, at $84-86$ (discussing these two incidents).

374. Id. at 86 .

375. See e.g., Am. Conservative Union, CPAC 2019-L/Col Ollie Norlh, YouTubl: (Feb. 28, 2019), https://www.youtube.com/watch?v=qlpigsTXH9U $\quad\left[\right.$ https://perma.cc/ $\left.\mathbf{H}_{5} \mathrm{HP}-\mathrm{Y}_{9} \mathrm{VX}\right]$ ("They want to disarm you. No Second Amendment, no individual freedom, no civilian ownership of firearms period." (quote starts at 09:40 and ends at 04:22)).

376 . See LAPIIRRL, supra note 368 .

377. North, supra note 31 .

378 . Id. 
worse) policing, the standard-bearer of the civil liberties narrative is a white, law-abiding "patriot" who believes he is besieged by both criminals and despotic officials who aim to render him defenseless.379 According to this narrative, the cultural and literal survival of the patriotic (white, rural) American is at stake. According to the NRA and other gun rights proponents, the Second Amendment is the only thing that can save the patriotic gun owner from oblivion. $3^{80}$ Given the nature and scope of the conspiracy to disarm, only a certain kind of constitutional right will suffice.

In sum, by the early 1990s, the NRA's internal politics had produced a leadership opposed to all forms of gun control. $3^{81}$ Since that time, the organization has played a significant role in popularizing the notion that all forms of gun control threaten to destroy the Second Amendment and presage the government's confiscation of firearms..$^{82}$ As one commentator observed, "[u]nder the guise of protecting civil liberties, the [NRA] cultivated a political reputation advocating for the protection of gun rights across federal, state, and local laws." 383

In 1997, Charlton Heston, then an NRA spokesperson and first vice president of the organization, articulated in combative terms the central logic of the modern civil liberties frame. In a speech on the NRA's future, he said:

I simply cannot stand and watch a right guaranteed by the Constitution of the United States come apart under attack from those who either can't understand it, don't like the sound of it, or find themselves too philosophically squeamish to see why it remains the first among equals: Because it is the right we turn to when all else fails. That's why the Second Amendment is America's first freedom..$^{8_{1}}$

As the speech suggests, the dominant civil liberties narrative contends that the only way to prevent confiscation and despotism is to treat the Second Amendment as a preeminent right. The Second Amendment's "preeminence" and "first-ness" dictate its absolutism. $3^{8{ }_{3}}$

379. See Siegel, Dead or Alive, supra note 5, at 232-33 (highlighting "unmistakably racialized" NRA arguments in favor of gun rights).

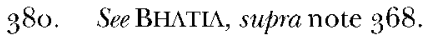

381 . Siegel, Dead or Alive, supra note 5 , at 228 .

382 . See BIIATIA, supra note 368 .

383. Id.

$3^{8}$. See National Rifle Association Future, C-SPAN (Sept. 1 1, 1997), https://www.c-span.org/ video/?9o8 $57^{-1} /$ national-rifle-association-future [https://perma.cc/R7 $\mathrm{U}_{4}$-VR6Q] (quote appears at $15: 02$ ).

$3^{85}$. See, e.g., Berger, supra note 369; Bob Owens, This Lausuil Conuld Shaller ALL lederal Gun Control Laum, BlARING ARMS (Nov. 22, 2016, 12:49 PM), https://bearingarms.com/ bob-o/2016/11/22/this-lawsuit-could-shatter-all-federal-gun-laws [https://perma.cc $/{ }_{3} \mathrm{PAE}$ $\left.\mathrm{CZ}_{3} \mathrm{X}\right]$ (" $[\mathrm{T}]$ he Second Amendment meant the federal government in Washington had no power to constrain or regulate arms ...."). The organization Gun Owners of America describes itself as 
Although most gun owners accept some limits on the right to keep and bear arms, fringe groups, militias, and other uncompromising advocates have dominated the civil liberties framing of the Second Amendment. ${ }^{866}$ As Adam Winkler has observed, the modern gun rights lobby, including most notably the NRA, "oppose[s] nearly every gun control proposal because any law regulating guns threatens to put us on a slippery slope to involuntary disarmament. Pass this law, and eventually all civilian guns will be confiscated." ${ }^{87}$

This libertarian framing of gun rights has led to claims that judicial decisions upholding bans on certain types of assault weapons or banning concealed carry have effectively "repealed" the Second Amendment..98 It is also associated with arguments that governments are powerless to respond to mass shootings with measures such as universal background checks, limits on the number or types of weapons an individual can possess, and bans on "bump stocks" and other weapons-enhancers, absent proposal and ratification of a constitutional amendment. ${ }^{8}{ }_{9}$ Commentators have devoted countless articles and commentaries to assuring readers that the Second Amendment is not an absolute right. 390 That so many deem this effort to be necessary is a manifestation of just how successful the Second Amendment's civil liberties narrative has been at shaping public discourse about gun rights and gun control.

One strategy has been to insist that the Second Amendment be treated the same as other fundamental civil liberties, in particular the First Amendment's freedom of speech.991 This part of the narrative sometimes relies on "second-class" terminology, which purveyors of the civil rights frame

the "no compromise" gun lobby. See About Gun Oumers of America, Gun Ownlirs of AM., https://gunowners.org/about-goa [https://perma.cc/N892-B] 84 ].

386 . WINKIIIR, supra note 127 , at 9 .

387 . Id. at 8 .

388. See Declan McCullagh, 2 New Count Decisions Are Quietly Eliminating Californians' Second Amendment Rights, REASON (May 10, 2018, 5:95 PM), https://reason.com/2018/05/10/ two-new-court-decisions-are-quietly-elim [https:// perma.cc/Q97T-AWP2].

389 . See Garrett Epps, The Second Amendment Does Not Transcend All Others, A'Tl ANIIIC (Mar. 8, 2018), https://www.theatlantic.com/politics/archive/2018/03/second-amendment-text-context/ 555101 [https://perma.cc/JTH5-87 CG] (discussing such claims by gun rights supporters and others). 39o. See, e.g., id.; Corey Brettschneider, Why the Real Defenders of the Second Amendment Oppose the NRA, GUARIJIAN (June 5, 2019, 4:14 PM), https://www.theguardian.com/commentisfree/ $2018 / \mathrm{mar} / 17 / \mathrm{second}-a m e n d m e n t-n r a-c o r e y-b r e t t s c h n e i d e r \quad[\mathrm{https}: / /$ perma.cc $/ \mathrm{M} 2 \mathrm{RY}-\mathrm{PK} 8 \mathrm{Q}]$ ("As many a gun enthusiast is eager to say, gun regulation is a non-starter; the second amendment is the law of the land, so the government can't tell me what to do with my guns."); Gordon L. Weil, School Kids Face 'Absolute' Gun Right, PORTLAND PREss HERALD (Nov. 12, 2019), https:// www.pressherald.com $/ 2018 / 0_{5} / 25 /$ school-kids-face-absolute-gun-right [https://perma.cc/ L9YC-VR76]; Robert Farago, Are Yon a Second Amendment Absolutist?, Jiws FOR PRis. GUN RIS. (May 29, 2016), http://jpfo.org/alerts2o16/alert20160524.htm [https://perma.cc/UD4Z-6AFZ].

391. See Winkile, supra note 127 , at 9 ("The gun lobby insists that the right to own a gun, like the right to free speech, should be robust, unfettered, and uninhibited by government regulation."). 
have also used to encourage courts to take a more active role in reviewing gun regulations. 392

In the civil liberties context, gun rights advocates seek to establish something like fundamentality-by-association. They rely on the free speech analogy to argue that courts must subject all gun control measures to strict judicial scrutiny and treat them as presumptively unconstitutional.393

This argument has gained some traction in the courts. 391 For example, as Justice Thomas has argued, "[b]ecause Second Amendment rights are no less protected by our Constitution than other rights enumerated in that document," the Court must skeptically review lower court judgments upholding gun regulations.995 Politicians have also embraced the fundamental rights approach, insisting that any discussion of gun control must begin from the premise that the Second Amendment is a "fundamental right." As Senator Chuck Grassley (R-IA) has put it, "[t]he Second Amendment right to bear arms is a fundamental right, and any legislative action must start and finish with recognition of this fact." 396

These arguments may sound less absolutist than the libertarian account advanced by the NRA. However, they similarly lead to the conclusion that most, if not all, gun control laws violate the Second Amendment. The fact that this assumption is inaccurate as it pertains to freedom of speech and many other fundamental rights has not deterred litigants and commentators from presenting their absolutist claims. 397

\section{The "Freedom Lovers" Narrative}

A final, mostly political dimension of the modern civil liberties framing of the Second Amendment posits a sharp distinction between "freedomloving" gun rights advocates and "freedom-hating" gun control proponents. $.9^{8}$ This part of the narrative glorifies gun rights proponents and demonizes those calling for adoption of gun control measures of any kind.399

392. See sources cited supra note 219 .

393. See, e.g., Brief for Petitioners at $3^{0-92}$, N.Y. State Rifle \& Pistol Ass'n, Inc. v. City of New York, 140 S. Ct. 1525 (2020) (No. 18-280) (arguing that since the Second Amendment is a "fundamental right," restrictions on its exercise must be subjected to strict judicial scrutiny).

394. See generally Ruben \& Blocher, supra note 198 (empirically examining influence of "second-class" claims).

395. Jackson v. City of San Francisco, 135 S. Ct. 2799, 2799-800 (2015) (Thomas, J., dissenting from denial of certiorari).

396. 162 CONG. REC. S4, 349 (daily ed. June 20, 2016) (statement of Sen. Chuck Grassley) (emphasis added).

397. See Zick, supra note $\mathbf{1}_{5}$, at $671-73$ (addressing.judicial scrutiny of speech regulations).

398 . See BIIAIIA, supra note 368 .

399. See id. ("The NRA generically vilifies people who represent and advocate for liberal and progressive gun policies, labeling them the "violent Left."'). 
The NRA routinely tells its members and the public that gun control proponents "hate your freedom and despise your Second Amendment." 40o The organization presents itself as a critical backstop needed to preserve the freedoms of law-abiding citizens. As Chris Cox, chief lobbyist for the organization, claimed at the 2018 NRA annual convention, "[ $\mathrm{t}]$ ogether, we're the most bare-knuckled defenders of individual freedom in American history." ${ }^{\circ 1}$ In an NRA TV ad campaign, NRA Executive Vice President Wayne LaPierre claimed, "[t]he only truly free people who have ever walked this earth have been armed people capable of defending themselves and their families." 402

The message is clear: Only an armed people can truly be free, and people cannot be armed and free unless they are free to be armed. If "freedomhating" Democrats, liberals and progressives are successful in their efforts to destroy the Second Amendment, the frame contends, civil liberty as we have come to know it will be lost. The narrative device is quite familiar to the NRA: The organization used a similar narrative during the 197 os and 1980 os to distinguish "law-abiding" Americans from criminals. $1^{\circ} .3$

In sum, gun rights advocates have developed and deployed narratives that construct realities in which self-defense against crime is the paradigm of liberty, governments are committed to disarming the people, and gun control advocates are unpatriotic freedom-haters. These narratives paint a vivid picture of the American patriot, besieged by both private violence and a wellorganized and deep-pocketed "disarm America movement." $4{ }_{4} 4$ Gun rights advocates have translated the fears and aspirations of this civil liberties narrative into constitutional arguments that cast the Second Amendment as an individual, inalienable, and "fundamental" right entitled to absolute protection from governmental regulation.

\section{THE CIVIL LIBERTES AGENDA}

As with the civil rights frame, there is an agenda associated with the Second Amendment's civil liberties framing. Here there are actually two broad agendas, one political and the other judicial.

\footnotetext{
40o. Wayne LaPierre, We Won With Thump, Gorsuch and Kavanaugh, But the Fight Is Not Over, AM.'S FIRST FREFDOM: STANDING GITARD (Nov, 22, 2018), https://www.americas I stfreedom.org/ articles $/ 2018 / 11 / 22 /$ standing-guard-we-won-with-trump-gorsuch-and-kavanaugh-but-the-fightis-not-over [https://perma.cc/3KRN-4ZRX].

401. Chris W. Cox, Address at the 2018 NRA Annual Meeting \& Exhibit (May 5, 2018 ).

402. See NRA, Ireedom's Safest Place; Thuly Free, YouTubl (Mar. 24, 2016), https:// www.youtube.com/watch?v=tiEwFgoilqo [https://perma.cc/ $\left./ \mathrm{T}_{3} \mathrm{XE}-7 \mathrm{X}_{5} \mathrm{~A}\right]$.

403. See discussion supra Section III.B.ı.

404. BHATL, supra note 368 (quoting Am. Conservative Union, supra note 375 ).
} 
If we take its leaders, publications, and public pronouncements seriously, the NRA's political agenda is simply an end to all gun control.405 This entails not just invalidation by courts of existing regulations but, more importantly, resistance to the enactment of any future regulations. While that position is not representative of the views of all gun owners, or even NRA members, ${ }^{106}$ this has been the organization's political posture since at least the early $19805.1^{197}$

Ever since the NRA adopted the "law and order" frame during the $197 \mathrm{os}$, it has pressed the notion that law-abiding gun owners need arms to defend themselves against lawless "others." ${ }^{08}$ As explained, the civil liberties frame also encourages gun rights supporters to view political officials and governments as declared "enemies" of freedom and liberty. ${ }^{409}$ It insists that any gun regulation, no matter how small its effect on the exercise of Second Amendment rights, presents an existential risk to Second Amendment rights. $1^{10}$ In its short form, the "Disarm America Movement" is coming for your guns and only the absolute and ironclad Second Amendment can stop it.

The civil liberties frame deploys these arguments to rally Americans around both individual self-defense (autonomy) and anti-tyranny justifications for interpreting and expanding the scope of the Second Amendment.4" Like other frames, it identifies common enemies and taps into existing cultural resentments and grievances. ${ }^{12}$ It encourages all persons, not just African-Americans, women, LGBTQ persons, and other members of marginalized groups, to place their political faith in an armed citizenry.419 The political plan of attack is simple and straightforward: to support officials who adopt Senator Grassley's perspective on the Second Amendment and to oppose politicians who propose and support gun control regulations.

405. Sep WINKI ER, supra note 127 , at 9 ("Almost any gun control infringes the Constitution, in their view, and nearly every law puts us on the inevitable pathway to civilian disarmament.").

4o6. See Scott Clement, go Percent of Americans Want Expanded Background Checks on Guns: Why Isn't This a Political Slam Dunk?, WASH. POST (Apr. 3, 2019), https:/ /www.washingtonpost.com/ news/the-fix/wp/2013/o4/og/go-percent-of-americans-want-expanded-background-checks-onguns-why-isnt-this-a-political-slam-dunk [https://perma.cc/Z8GZ-HR ${ }_{4} \mathrm{H}$ ] ("Nine in 10 Americans support expanding background checks on gun purchases.").

407. See Siegel, Dead or Alive, supra note 5, at 209 ("Unlike law and order discourse, the gun rights claim voiced a libertarian spirit that was increasingly hostile to the government in any guise.").

408. Id. at $208-09$.

4\%9. See discussion supra Section IV.B.

$410 . \quad I d$.

411. See BloCHER \& Miller, supra note 34, at 160-69 (discussing Second Amendment theories or justifications).

412. See Benford \& Snow, supra note 9, at 615-16 (discussing "injustice frames" and "adversarial framing").

413. See discussion supra Section IV.B. 
The judicial agenda seeks to accomplish similar aims in the courts. There, gun rights proponents have deployed civil liberties-type arguments primarily to affect the level of judicial scrutiny applied to gun control measures. ${ }^{14} \mathrm{Gun}$ rights advocates either want courts to adopt a categorical rule that many or most gun regulations are unconstitutional, or to apply a high degree of judicial scrutiny to gun control measures across the board..$^{1.5}$

Since its application may prove to be fatal to gun regulations, it is not surprising that "strict" judicial scrutiny is one of the agenda items of the civil liberties frame. ${ }^{46}$ Here, however, the justification for heightened scrutiny is not that gun regulations are inherently racist and discriminatory, as under the civil rights frame, ${ }^{417}$ but rather that the Second Amendment is a "fundamental" right. ${ }^{48}$ As noted, in this context, "second-class" claims are part of a strategy for establishing a level of scrutiny that will result in the invalidation of most, if not all, gun regulations.

Merging these political and constitutional agendas, the NRA has encouraged state legislatures to propose and adopt constitutional amendments establishing strict judicial scrutiny for all gun regulations. $1^{19}$ Setting a standard of scrutiny, which is something Heller expressly declined to do, would have an obvious impact on the future development of the right to keep and bear arms. Although tiered scrutiny is breaking down across fundamental rights and "strict" scrutiny has never been quite as fateful or fatal as many have suggested,400 gun rights advocates nevertheless consider establishing it as the default Second Amendment standard to be a critical component of the civil liberties agenda.

414. See, e.g., Brief for the Nat'l Rifle Ass'n \& the NRA C.R. Def. Fund as Amici Curiae in Support of Respondent at $16-21$, District of Columbia v. Heller, 554 U.S. 570 (2008) (No. $07^{-}$ 29o) (urging the Court to apply strict scrutiny to infringements of Second Amendment rights).

415. See, e.g., Brief for Petitioners, supra note 393, at 30-32 (arguing that strict scrutiny should apply to New York City regulations concerning transport of firearms).

416. See, e.g., supra notes $4^{1} 4^{-15}$.

417. See discussion supra Section III.D.

418. See, e.g., Petitioners' Reply Brief, supra note 242, at 2 ("This Court's review is further warranted because the deferential form of intermediate scrutiny applied by the panel majority below is inconsistent with this Court's precedents regarding how infringements on fundamental rights are analyzed and demonstrates how the lower courts are turning the Second Amendment into a second-class right.").

419. See generally Todd E. Pettys, The N.R.A.'s Strict-Scrutiny Amendments, 104 IOWA L. Rrv. 1455

(2019) (describing and analyzing state constitutional amendments).

420. As Professor Winkler observes,

the old adage about laws infringing fundamental rights being subject to strict scrutiny remains a favorite of scholars, judges, and law students. And it is flatly wrong.... It is time the fundamental truth be told: laws infringing upon fundamental rights are subject to strict scrutiny, but only some of those rights, only some of the time, and only when challenged by some people.

Adam Winkler, Fundamentally Wrong About Fundamental Rights, 23 CONST. COMMENT. 227,239 (2006). 


\section{CIVIL LIBLRTLS RHETORIC VERSUIS REALTTY}

Accepting Heller and McDonald as the law of the land, the Second Amendment is plainly a fundamental constitutional right and part of the Constitution's system of civil liberties. ${ }^{21}$ However, gun rights advocates often overstate the political and constitutional consequences of the Second Amendment's status.

\section{1. "Liberty" Versus "License"}

Gun rights advocates often invoke what sounds like a natural rights understanding of the Second Amendment. Thus, like Blackstone, they emphasize the existence of certain inalienable, fundamental, and "absolute" rights government must respect. $4^{22}$ They place the right to keep and bear arms in that category.

However, as discussed in Section IV.A, while Blackstone and other early commentators recognized certain rights as inalienable and absolute, they also distinguished the exercise of "liberty" from the enjoyment of "license." ${ }^{23}$ Thus, Blackstone understood that although the right to personal security was absolute, "auxiliary" rights supporting it, including the right to keep and bear arms, were subject to limitations relating to the concerns of civil society.121

Heller and McDonald rendered originalist interpretations of the Second Amendment. Yet it is clear that even at the time of the Second Amendment's ratification, "civil liberties," including the right to keep and bear arms, were subject to various limitations..$^{42}$ Indeed, Justice Scalia acknowledged as much in Heller, when he emphasized: "Like most rights, the right secured by the Second Amendment is not unlimited." ${ }^{206} \mathrm{He}$ explained, for the majority, that individuals did not have the right to "carry any weapon whatsoever in any manner whatsoever and for whatever purpose."127 Indeed, Heller acknowledged various specific limits on the right to keep and bear arms, including (but apparently not limited to) felon dispossession, restrictions on carrying "dangerous and unusual weapons," bans on possession in certain "sensitive places," and historical bans on concealed carry..$^{28}$

Heller's reality plainly defies the absolutist rhetoric of the NRA and other gun rights supporters. Although it does not use the specific vocabulary, the Court just as plainly rejects as "license" the notion that the Second Amendment is unbounded by civil concerns. Indeed, by accepting various

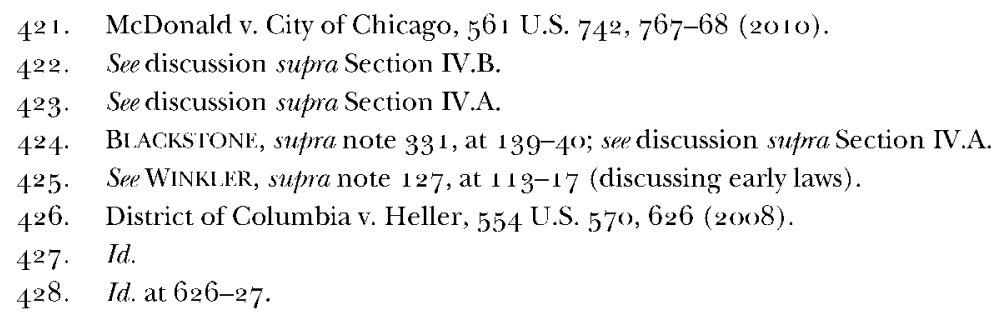


limits on the right, Heller squarely acknowledged the "civil" dimension of the Second Amendment. Furthermore, commentators and historians have documented that considerations of public order and safety have always limited and constrained the right to keep and bear arms. ${ }^{299}$ As Professor Winkler observes, "[a]lthough the fact is rarely discussed in the individual-rights literature, the founding generation had many forms of gun control." $13^{\circ}$ Thus, history unequivocally demonstrates that this civil liberty, like others, can comfortably co-exist with government regulation. "Gun rights and gun control are not only compatible; they have lived together since the birth of America." $43^{1}$

\section{The Second Amendment's Imminent Destruction}

A recurring dystopian theme of the civil liberties frame is that gun owners must resist all gun control measures because they represent an existential threat to firearms liberties. ${ }^{132}$ In this frame, a government-mandated background check or a registration requirement is simply the first step toward disarming the people. 133

In reality, the Second Amendment is not in any existential danger. At present, the right to keep and bear arms enjoys not only constitutional recognition as a "fundamental" right, but widespread political support as well.434 Thus, Americans are not clamoring for the Second Amendment's repeal in any significant numbers. Indeed, polling shows that an overwhelming majority of Americans accept the individual right to bear arms as fundamental, even if they disagree on certain regulations of the right. 435 As Professors Blocher and Miller have observed, "the core holding of Heller is politically and legally secure, and everyone should accept that fact." ${ }_{13}{ }^{6}$

As discussed in Part III, state legislatures have enacted affirmative legal and constitutional protections for the right to keep and bear arms.137 Most states have preempted local lawmaking on gun rights, specifically in order to constrain or prevent local gun control. $13^{8}$ Some have adopted constitutional amendments establishing strict scrutiny as the default standard for gun regulations under their constitutions,439 and "Second Amendment

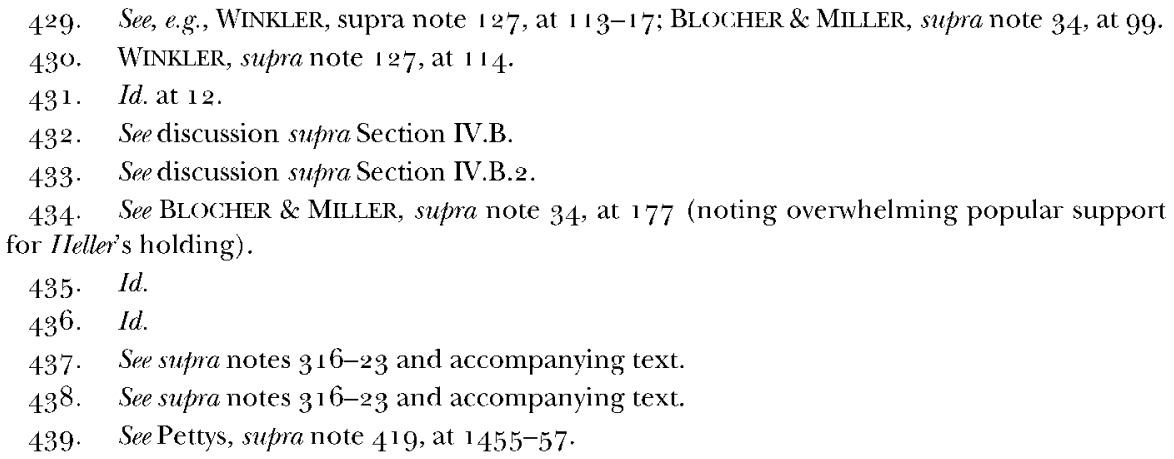


sanctuar[ies]" now dot the American landscape. $.4^{\circ}$ Further, it is currently the law of the land in almost every state that gun owners can carry weapons in public in either concealed or open manners. $11^{1}$

These measures expand the right to keep and bear arms beyond what was recognized in Heller and McDonald. The current reality of gun rights in the United States directly undermines one of the principal tropes of the civil liberties frame: "These pro-gun efforts challenge the standard narrative of gun owners as libertarians fighting off an over-reaching regulatory state."112

These facts and political realities contradict the NRA's apocalyptic rhetoric about the looming threat posed by a "Disarm America Movement." 443 As Professors Blocher and Miller observed, "[a]lthough no amount of open and repeated support for the Second Amendment will satisfy those with political or financial incentives to claim otherwise, anxieties about the right's future are largely unfounded, and stand in the way of useful discussions about gun rights and regulation."114

\section{3. "Second-Class" Claims}

Courts, including the Supreme Court, have not treated the Second Amendment as a "second-class" civil liberty.445 As explained in Parts III and $\mathrm{IV}$, claims to the contrary, which gun rights advocates continue to press in courts, disregard the nature and diversity of judicial review in the area of constitutional rights. $44^{6}$

The primary constitutional argument associated with this specific complaint is that Second Amendment claims must receive strict scrutiny owing to the fundamental status of the right in question, and that strict scrutiny will almost always be fatal to gun regulations.117 Neither claim is accurate. The fact that gun regulations are not always subject to strict scrutiny does not signal any judicial disrespect for the Second Amendment. For example, some regulations of speech do not trigger any scrutiny at all. $11^{8}$ Only

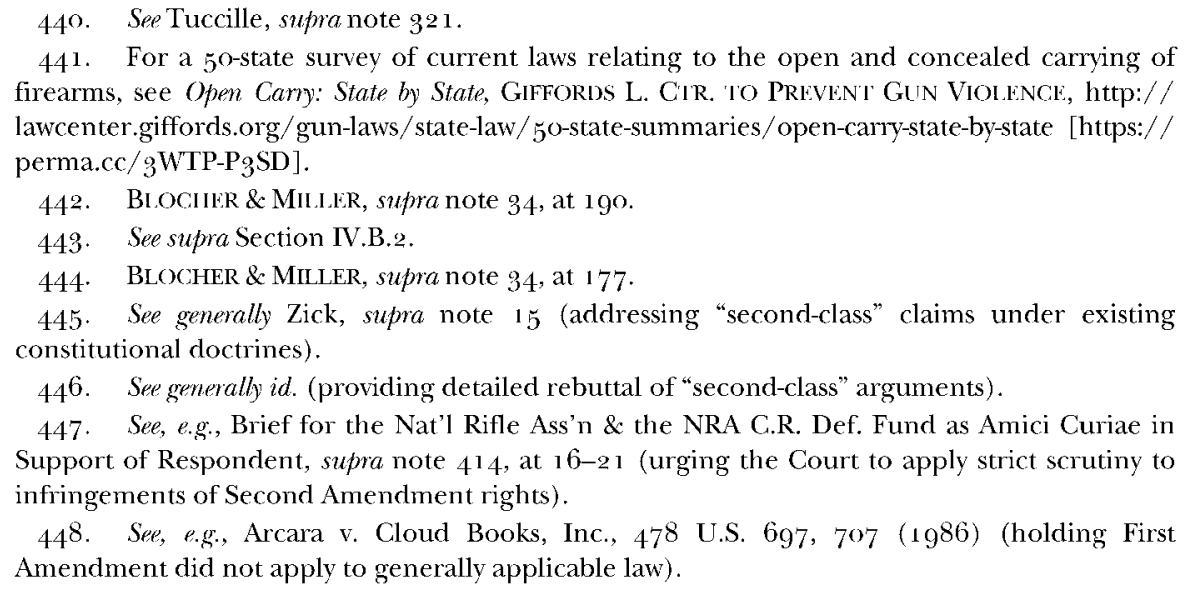

441. For a $5^{\circ-s t a t e ~ s u r v e y ~ o f ~ c u r r e n t ~ l a w s ~ r e l a t i n g ~ t o ~ t h e ~ o p e n ~ a n d ~ c o n c e a l e d ~ c a r r y i n g ~ o f ~}$ firearms, see Open Carry: State by State, GIFFordos L. CirR. TO PRLvinT Gun VIOLlincl, http:// lawcenter.giffords.org/gun-laws/state-law/50-state-summaries/open-carry-state-by-state [https:// perma.cc/3WTP-P3SD].

442. BLOCIILR \& MILLLR, supra note 34 , at 190.

443. See supra Section IV.B.2.

444. BLOCHER \& MilleR, supra note 34 , at 177.

445. See generally Zick, supra note $1_{5}$ (addressing "second-class" claims under existing constitutional doctrines).

446. See generally id. (providing detailed rebuttal of "second-class" arguments).

447. See, e.g., Brief for the Nat'l Rifle Ass'n \& the NRA C.R. Def. Fund as Amici Curiae in Support of Respondent, supra note 414, at 16-21 (urging the Court to apply strict scrutiny to infringements of Second Amendment rights).

448. See, e.g., Arcara v. Cloud Books, Inc., 478 U.S. 697, 707 (1986) (holding First Amendment did not apply to generally applicable law). 
a relatively small class of measures, those that expressly target the content of speakers' messages, are subject to strict scrutiny; other speech regulations are subject to an array of standards, from explicit balancing tests, to specific limits on the "disruptive" speech of students in public schools, to no scrutiny at all..19 Indeed, First Amendment doctrine tolerates a wide variety of incidental burdens on speech.

In order to convince courts to apply the highest possible level of scrutiny to gun regulations, gun rights proponents have deployed a caricature of fundamental rights. Their rhetoric ignores the reality that many other civil liberties, including the protection against unreasonable searches and seizures, limits on the taking of private property for public use, voting rights, abortion rights, and marriage rights are subject to a dizzying array of constitutional standards. $45^{\circ}$ When it comes to civil liberties, there is no one-size-fits-all doctrine or standard of review. $43^{1}$ There are no absolute or "ironclad" rights.

What many gun rights advocates seem to want is not "first-class" treatment, but a form of special status-a right that triggers strict judicial scrutiny any time officials regulate firearms, and a form of judicial scrutiny that is nearly always fatal in fact. However, as scholars have explained at length, this is not how fundamentality and strict scrutiny actually operate in the area of constitutional rights. ${ }^{152}$

Even setting aside the difficulties of comparing treatment of rights across subject matter areas, one thing is clear: Courts have afforded the Second Amendment the recognition and respect shown other fundamental rights.453 Much of the consternation relating to lower court review is owing to the lack of clarity and other limitations of Heller.454 As Professors Blocher and Miller have observed, "[b]y and large, lower courts seem to be engaged in a good faith effort to follow a conflicting and confusing opinion in an environment where mistakes carry significant risks." 155

\section{FRAMING EFFECTS: DISGOURSE, DOCTRINE, AND THEORY}

As I have argued, aspects of the civil rights and civil liberties narratives deployed by gun rights advocates are revisionist or overclaim. $45^{6}$ However,

\footnotetext{
449. See Zick, supra note 15 , at $67 \mathbf{1}-75$ (discussing judicial review of speech claims).

$45^{\circ}$. See id. at $659-60$.

$45^{1}$. See generally Winkler, supra note 420 (examining the diversity of judicial standards applied to regulations affecting "fundamental" rights).

452. See generally Richard H. Fallon, Jr., Strict fudicial Scrutiny, 54 UCLA L. Riv. 1267 (2007) (observing that strict scrutiny has not been a reliable or consistent indicator of fundamentality); Winkler, supra note 420 (examining the diversity of judicial standards applied to regulations affecting "fundamental" rights).

453. See Zick, supra note 15 , at $63^{8-41}$.

454. See id. at $646-47$ (noting lower court caution in the face of Heller's ambiguities).

455. BLOCHER \& MILLER, supra note 34 , at 185 .

$45^{6}$. See supra Sections III.E., IV.D.
} 
these frames have significantly affected, and will continue to affect, the meaning and enforcement of the right to keep and bear arms. If we want to know how courts, lawmakers, and the public have constructed the modern Second Amendment, these two frames are an illuminating place to look. Their development and communication also present a cautionary tale for gun control advocates about the need to develop effective counter-frames.

\section{A. TIIE POWER AND PERSISTENCE OF SECOND AMENDMENT FRAMES}

The framing of the Second Amendment demonstrates that the language of constitutional rights matters-a lot. Thus, it matters that we now think and write about the Second Amendment as an "individual" and "fundamental" right. These concepts have legal, social, and political meaning. They are also rhetorically powerful. 157 One indication of this power is their persistence over time. Gun rights advocates have now situated the Second Amendment within a longstanding rights tradition, one that prizes both "civil rights" and "civil liberties." The two frames are useful not only to the organized gun rights movement, but also because they provide individuals with a vocabulary for debating the meaning of the Second Amendment.

The Second Amendment's framing confirms that rights are a form of both rhetoric and power. As Professor Schmidt has explained, "[t]he civil rights-civil liberties divide has always served as a vehicle to advance certain substantive claims. It has always been a way to structure debates about which kinds of rights should be favored and which ones should be limited." $45^{8}$ As we have seen, so it has been with regard to gun rights arguments. These "are not just arguments about guns; rather, they are arguments about a whole collection of values, for which guns serve as a symbol." 159 In the Second Amendment context, those values include equality, autonomy, freedom from despotic rule, and respect for cultural beliefs and practices.

The story of the Second Amendment's framing is an example of the dynamic relationship between rhetoric and rights. Although commonly understood in the modern era as separate and distinctive concepts, ${ }^{60}$ gun rights advocates have simultaneously deployed both civil rights and civil liberties frames. So far, both frames have paid significant dividends.

Like social movement frames more generally, Second Amendment frames have organized and structured national debates about the nature and scope of gun rights. Narratives about "discrimination" and "disarmament"

\footnotetext{
457. For a discussion of the power of rhetoric to influence constitutional meaning, see generally Ruben \& Blocher, supra note 198 .

458 . Schmidt, supra note 17 , at 36 .

459. Williams, supra note 221, at 395; see also Maxine Burkett, Much Ado About . . Something Else: D.C. v. Heller, the Racialized Mythology of the Second Amendment, and Gun Policy Reform, 12 J. GENDER RACE \& JUST. 57, $5^{8}$ (2008) (interpreting the Ieller dispute as being primarily about race discourse and gun rights).

$4^{60}$. See Schmidt, supra note 17 , at $3-5$.
} 
have presented distinctive frames to the public, in the hope that they resonate with individuals within and outside the gun rights movement. Through public discourse, the two frames have significantly affected social, political, and constitutional perceptions of rights..$^{1_{\perp}}$ They have functioned both within and outside the courts and other formal lawmaking institutions. As constitutional culture theory suggests, as they have become rooted in discourse and constitutional culture, the civil rights and civil liberties frames have affected laws, public policies, and judicial decisions. $1^{62}$

Moreover, the civil rights and civil liberties narratives have encouraged gun rights supporters to think of their rights-and their persons-in distinctive ways. The equality frame points to anti-discrimination and antisubordination concerns. $4^{63}$ It emphasizes the danger of discriminatory gun laws as well as the prospect of "second-class" treatment of those who support gun rights and their constitutional concerns. $4^{64}$ Framing the Second Amendment as a "civil right" associates gun rights and gun owners with America's abolitionist history, Brown's legacy, and the civil rights movement led by Dr. Martin Luther King, Jr. $1^{6} 6_{5}$ The civil liberty frame focuses on the tradition of inalienable rights, individual autonomy and self-preservation. ${ }^{66}$ It associates gun owners with the colonists who led a revolution, the nation's founders, and the settling of America's rugged frontiers..$^{1{ }^{6} 7}$ It conjures a David-Goliath relationship between the powerful state and the overpowered and outgunned individual, and marks distinctions between "freedom-loving" gun rights supporters and "freedom-hating" advocates of gun control.468

As social movement scholarship suggests, these frames have identified common enemies, facilitated common causes and motivated collective action. $4^{69}$ They are all integral to the "gun rights movement." At the same time, the various frames and narratives about gun rights have also provided individuals with critical tools for making sense of and arguing about a nuanced right with a long and complex history. Social movement organizations, in particular the NRA, have played a significant role in terms of generating and deploying these frames. However, individuals have also used them as constitutional short hands and memes.

\footnotetext{
461. See Siegel, Dead or Alive, supra note 5, at 193 (noting "how contest over the Constitution's meaning can endow courts with authority to change the way they interpret its provisions").

462. See Siegel, Constitutional Culture, supra note 8, at 1327 (explaining that constitutional culture, including framing and narratives, "mediates the relation of law and politics").

463. See discussion supra Part III.

$46_{4}$. See discussion supra Part III.

$4^{6} 5$. See discussion supra Part III.

466. See discussion supra Section IV.B.

467. See discussion supra Section IV.B.

468. See discussion supra Section IV.B.

469. See sources cited supra notes 8-9.
} 
In our divisive gun debates, advocates sometimes use frames to troll or antagonize their opponents.47 ${ }^{\circ}$ In this sense, frames can operate outside the collective action scheme of social movements. For advocates, they serve not just collective functions but more individualistic ones, too. These deployments are not part of any sophisticated social movement agenda. Rather, they provide a vocabulary for responding to constitutional and policy arguments. That is not to say they lack sophistication, but rather to suggest that the functions or uses of frames can be far blunter and more instrumental than often understood.

Both the civil rights and civil liberties frames have evolved significantly over time. As they have done so, each has developed increasingly aggressive strains-e.g., "gun control is racist" and disarmament-inspired gun rights absolutism.47' Among their other benefits, these shorthand frames have particular value in social media and other popular fora. Gun rights advocates have used the civil rights and civil liberties frames to reduce gun policy debates to soundbites, bumper sticker slogans, and internet memes. This makes it much harder to defeat or respond to them with nuanced constitutional, historical, or policy arguments about race and guns or gun control and tyranny. The mere invocation of "the Second Amendment" is intended to end any debate.

In general, social movements tend to use frames not just to identify opponents and grievances, but also to provide or suggest solutions to collective problems.472 In the case of the Second Amendment, the discrimination and disarmament frames have posited problems that generally do not exist-for example, racially discriminatory and confiscatory gun laws. 473 Advocates have used the frames first to generate these purported evils, and next to provide arguments for defeating proposals that would limit Second Amendment rights in any respect.

We might expect frames to recede or disappear if they or their purveyors lack significant credibility. However, despite their exaggerated nature and the NRA's own uneven opposition to gun control, Second Amendment discrimination and disarmament frames have persisted for many decades. The persistence of these frames demonstrates that their power does not relate solely to their ability to persuade outsiders, or even those who support gun rights. Rather, the most aggressive frames may serve more strategic or cynical

470. While no doubt a matter of faith to some, the "all gun control is racist" argument seems to be of this sort. So too, describing the political left as "violent" appears to be an attempt to turn arguments about gun violence against proponents of gun control. See ВНАТц, supra note 368 .

471. See discussion supra Sections III.B.3, IV.B.

472. See Siegel, Comstitutional Culture, supra note 8, at 1340-41.

473. See, e.g., Keith Collins \& David Yaffe-Bellany, About 2 Million Guns Were Sold in the U.S. as Virus Fears Spread, N.Y. Times (Apr, 2, 2020), https://www.nytimes.com/interactive/2020/ 04/o1/business/coronavirus-gun-sales.html [https://perma.cc/4ADW-AFMB] (reporting on ready access to firearms and increased sales, even during a pandemic). 
ends. They can manufacture a false sense of victimhood and outrage, and stoke irrational fears.474 The civil rights frame looks to co-opt the narratives and vocabularies of equality movements and apply them to a politically powerful minority of gun owners. It seeks to answer charges of the connection between guns and racism with the charge that gun control is itself racist. 175 The civil liberties frame conjures a confiscation "movement" that currently does not exist. $17^{6} \mathrm{It}$, too, creates a culture of paranoia and distrust.

The persistence of these frames likely speaks more to their political utility and cultural salience than to their ultimate persuasiveness. The NRA has masterfully marketed the Second Amendment as the only backstop standing between American society and a return to racist and tyrannical government. It has packaged the right along with the flag, the Founders, the National Anthem, and belief in God. This nationalist and cultural frame is an effective form of identity politics. It has divided rural from urban, faithful from faithless, and freedom from absolute despotism.

In sum, the rhetorical power of the Second Amendment's frames does not ultimately rest on the ability to convince gun rights advocates or their opponents on the merits. Rather, the power lies in the ability to construct sticky narratives of discrimination and disarmament that resonate with certain cultural communities. The frames are most useful insofar as they maintain gun owners in a constant state of grievance and paranoia.

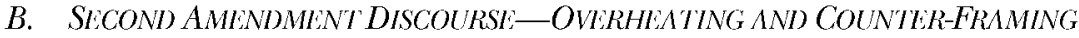

Heller and $M c$ Donald recognized and incorporated an individual right to keep and bear arms. Some scholars were optimistic that this would bring a significant measure of calm to gun rights rhetoric, and perhaps even make possible the passage of some popular gun control measures.17 However, the decisions settled relatively little. If anything, they opened up a new front in the Second Amendment framing war.

The democratic process in which framing occurs can act as a kind of binding agent, in the sense that it brings people together in a common interpretive endeavor. $4^{8}$ Moreover, as discussed in Part II, democratic constitutionalism presupposes that participants argue in good faith and base

\footnotetext{
474. See, e.g., FRANKs, supra note 116 , at $65^{-67}$ (discussing gun owners' victimhood narrative).

475. See discussion supra Section III.B.3.

476 . See discussion supra Section IV.B.2.

477. See WINKIER, supra note 127 , at 295 (noting that gun rights proponents and gun control advocates were hopeful that IIeller would reduce rhetoric about "disarmament" and help calm public discourse about gun rights).

478. See Siegel, Constitutional Culture, supra note 8, at 1406 (observing that rhetoric and framing offer "opponents in constitutional controversies incentive to reckon with the normative logic and popular appeal of opposing claims" and "structure [] a semantic field in which the Court can pronounce the Constitution's meaning").
} 
their arguments on shared understandings about common traditions. 479 From this perspective, constitutional discourse is a public good with independent value. Among other things, scholars suggest that collective discourse "forges community" and "civic attachment." 180 It can have the virtue, some maintain, of "cooling debate." 181

The story of the Second Amendment's framing casts at least some doubt on these premises and suppositions. $1^{82}$ In light of their overstatements and clumsy co-opting, it is difficult to characterize discrimination and disarmament as frames generally based on common understandings about our racial history or the nature of civil liberty. Rather, many of the tropes about racism and disarmament trade on dystopian fears. They largely ignore political, social, and legal realities, which suggests proponents may not be offering them in good faith or experiencing them as forging "civic attachment."

Second Amendment frames may bind advocates of the same persuasion together. However, they appear to do little if anything to accommodate opponents' concerns, "contribute to the public's confidence in the Constitution[]," or "vitalize" the system of constitutional lawmaking..$^{83}$ Indeed, racially charged and absolutist claims are more likely to heat up constitutional discourse than cool it down. In some instances that appears to be one of the goals. African-Americans told that gun control measures are the second coming of Jim Grow, and NRA members constantly warned that the government is poised to throw them to the criminal wolves are not being encouraged to participate in a nationally unifying exercise. Instead, they are being primed for perpetual culture wars.

At least with respect to the most aggressive Second Amendment framing, we ought to be very concerned about our overheated constitutional discourse. This concern relates directly to the dysfunction and political paralysis scholars have identified in contemporary gun debates. $1^{8}$. Democratic processes in which alarmist and dystopian framing prevails will naturally lead, as ours has, to stasis and gridlock. Dysfunctional rights discourse does not bind the people to one another in a common enterprise: It deepens existing cultural and political divides and precludes necessary compromises. Governments cannot and ought not to dictate how rights proponents and opponents communicate 
their constitutional narratives and frames. $4^{85}$ However, we need to pay more attention to the manner in which constitutional framing affects political community and, ultimately, policy outcomes. The civil rights and civil liberties frames have contributed significantly to the current political gridlock affecting firearms policy.

Of course, we cannot have a debate based on common traditions if gun control advocates do not get in the game and play some offense. This is not to suggest they have been silent or absent in gun debates. However, the political left has not developed either an effective counter-mobilization or successful counter-frame in response to the gun rights movement. $4^{86}$ That is not to suggest that gun control proponents follow suit by developing and deploying similarly aggressive and outlandish frames. ${ }^{487}$ Thus, for example, as I have explained, the "Second Amendment is racist" frame is not an effective answer to the gun lobby's discrimination narrative (which is more firmly grounded in history).$^{88}$ However, assuming it takes a frame to beat a frame, the playing field has to be more level. The debate might be less dysfunctional insofar as the other side engages in rational, but effective counter-framing..$^{89}$

Progressives are clearly playing catch-up in this regard. To some extent, this is understandable. For decades, they relied on the notion that the Second Amendment protected only a collective, militia-based right. $19^{\circ}$ While gun rights advocates were constructing and deploying law and order, discrimination, "freedom-loving," and disarmament narratives, gun control proponents were complacent.

Perhaps shocked into action by Heller, gun control advocates have begun to come out of their defensive crouch. Commentators and activists have started to generate some counter-frames. These include public health frames that emphasize the connection between guns and suicide, "human rights" frames that invoke concepts in international law, and even "going gunless" frames that trade on abstinence-like movements and rely on voluntary waiver of the right to possess firearms. 191

In a more promising development, an amicus brief filed in a recent Second Amendment case on behalf of members of March for Our Lives has

\footnotetext{
485. See generally Timothy Zick, Rights Speech, $4^{8}$ U.C. DAvIS L. Riv. 1, 3 n.2 (2014) (examining "the extent to which government may regulate communications regarding constitutional rights").

486. See Goss, supra note 49 , at $84^{-112}$.

487 . See WINKI leR, supra note 127, at 9-10 (describing extremist gun control advocacy).

488. See discussion supra Part III (discussing this counter-narrative).

489 . See Siegel, Constitutional Cullure, supra note 8, at 1362-64 (describing the dynamics of counter-mobilization).

49o. See, e.g., CoRNELL, supra note 7 , at 188.

491. See, e.g., Dru Stevenson, Gring Gunless, 85 BROOK. L. RHV. (forthcoming 2020); Leila Nadya Sadat \& Madaline M. George, Gun Violence and Human Rights, 6o WASI I. U. J.L. \& POL'Y 1, $3^{6-} 4^{2,} 5^{\circ}(2019)$.
} 
offered a more compelling frame.492 The brief presents the stark and sometimes gruesome narratives of victims of gun violence. ${ }^{493}$ It takes a step toward urging a collective constitutional assessment of the right to keep and bear arms, including the collective goods associated with gun control measures.191 In short, this counter-narrative seeks to change the focus from tradition and American history to the present-day consequences of the failure of gun control and the cost of that failure to democratic politics and collective constitutional rights. This argument, if more fully developed, could present a constitutional counterpoint to the civil rights and civil liberties frames.

So far, at least, the gun control counter-frames have not had much effect on the gun control debate. Efforts to de-legitimize or contest the individual rights interpretation of the Second Amendment have largely failed. Heller is the law of the land, and any progressive counter-framing of the Second Amendment must start with that reality.

\section{SECOND AMENDMENT DOCTRINE AND GLN LAWS}

The stakes of the framing contest are high, and they extend beyond winning public debates. With regard to the current and future right to keep and bear arms, there is still a great deal we do not know. Courts will need to fill an array of doctrinal gaps on matters ranging from the standard of review that they will apply to arms regulations, the places where persons can legally carry arms, and the types of arms they can keep and bear. Just as it influenced the road to Heller and McDonald, Second Amendment framing will continue to affect these doctrinal and legal issues in important ways.

Recognizing the principles of constitutional culture, Second Amendment scholars have observed, "constitutional doctrine is often formed in a crucible of contested meanings." 195 Advocates have contested the Second Amendment's meaning through democratic channels that include formal lawmaking, judicial decision-making, and public discourse. As this Article has shown, these contests have continued well after Heller.

Before and after Heller, gun rights advocates invoked the civil rights frame in scholarship, litigation, and public commentary. $49^{6}$ They hoped, then and

492. See generally Brief of March for Our Lives Action Fund as Amicus Curiae in Support of Respondents, N.Y. State Rifle \& Pistol Ass'n, Inc. v. City of New York, 140 S. Ct. 1525 (2020) (No. $18-280)$ (providing a new frame for the argument focused on victims of gun violence).

493. Id. at 3-22.

494. See Joshua Feinzig \& Joshua Zoffer, $A$ Constitutional Case for (xun Control, Ali ANIIC (Oct. 28, 2019), https://www.theatlantic.com/ideas/archive/2019/10/constitutional-case-guncontrol/600694 [https://perma.cc/4 $\mathrm{YER}_{5}{ }^{\mathrm{BV} 6}$ ] (describing the constitutional narrative framing March for Our Lives' brief).

495. BLOCHER \& Miller, supra note 34 , at 191 ; see also Post \& Siegel, Popular Constitutionalism, supra note 8 , at $104^{2-43}$ (exploring how constitutional meanings evolve as a result of public discourse and engagement); Post \& Siegel, Roe Rage, supra note 8 , at $379-84$ (discussing how abortion rights have been influenced by narratives about choice and health).

496. See discussion supra Part III. 
now, to influence the mode of judicial review and the degree of scrutiny courts apply to all gun control measures. Advocates have also successfully used the civil rights frame to encourage legislatures to adopt anti-discrimination and other pro-gun rights measures.197 In this regard, the civil rights framing of the Second Amendment has affected the substance of gun rights outside the courts. Like African-Americans, LGBTQ persons, and other protected minorities, gun owners now enjoy affirmative, equality-based legal protections.

Gun rights supporters are deploying the civil liberties frame toward similar substantive outcomes in courts. Heller and McDonald adopted a libertarian interpretation of the right to keep and bear arms. "Freedomloving" judges are now being encouraged to review gun control measures with a high degree of skepticism, through the libertarian and "fundamental rights" lenses. Gun rights advocates have borrowed concepts and specific doctrines from the preeminent civil liberty-the First Amendment's Free Speech Clause-for this project. $1^{8}$ Framing the Second Amendment in this image may lead to heightened scrutiny of and categorical limits on the government's power to regulate the right to keep and bear arms.

Even if in particular cases this sort of borrowing is unwarranted or illadvised, in general it forges a connection in the judicial mind between the Second Amendment right and a venerable tradition of civil liberties. As Heller shows, this connection can pay significant dividends in terms of the scope and substance of the Second Amendment.499 Particularly if courts can be convinced to downplay or ignore the distinction between "liberty" and "license," ${ }^{\circ o}$ and adopt the "second-class" mantra now pressed by litigants, gun rights proponents stand to make significant gains in terms of expanding the scope of Second Amendment rights.

\section{FRAMING SECOND AMENDMENT JUSTIFICATIONS}

The civil rights and civil liberties frames also speak implicitly to the justifications for protecting Second Amendment rights. In Heller, the Court grounded the individual right in values relating to individual self-defense..$^{\circ 1}$ However, that does not exhaust the theoretical possibilities..$^{02}$ Just as courts

497. See discussion supra Section III.D.

498. See Jackson v. City of San Francisco, 135 S. Ct. 2799, 2799-800 (2015) (Thomas, J., dissenting) ("Second Amendment rights are no less protected by our Constitution than other rights enumerated in that document ....").

499. See District of Columbia v. Heller, 554 U.S. 570, 582, 595 (2008) (invoking First Amendment). See generally David B. Kopel \& Joseph G.S. Greenlee, The Federal Circuits' Second Amendmen Doctrines, 61 Sr. LOUIS U. L.J. 193 (2017) (discussing lower courts' reliance on First Amendment in Second Amendment decisions).

5\%o. See discussion supra Sections IV.A, IV.D.

5\%1. Heller, 554 U.S. at $624^{-25}$.

502. See BIOCIILR \& Millile, supra note 34 , at 148-72 (examining various Second Amendment.justifications). 
and commentators have supported freedom of speech based on multiple justifications-e.g., self-government, the marketplace in ideas, autonomy $y^{5^{\circ 3}}$ -so, too, might the Second Amendment have multiple theoretical foundations.

This theoretical work is in its infancy, and frames may have a significant impact on how scholars and courts undertake it. In addition to self-defense justifications, courts could ground the right to keep and bear arms in the sorts of equality, autonomy, and anti-tyranny concerns associated with the civil rights and civil liberties frames..$^{\circ 4}$

The image of historically marginalized persons, including racial minorities and women, facing the threat of disarmament could lead courts in some cases to adopt equality-based justifications for protecting Second Amendment rights. A civil rights frame focused on equality values might encourage courts to take a more serious look at classifications based on age and other characteristics. Foregrounding equality might also lead them to question why some people, for example public officials, are entitled to armed protection while members of the public are not. $5^{05}$ More generally, courts might invoke the purportedly subordinating effect of gun control measures as a reason to be skeptical of gun control generally. They might even show an interest in the kind of "animus" reasoning that has been deployed to protect marriage equality and other rights.

The civil liberties frame may also generate future support for an autonomy right with regard to, for example, what kinds of arms an individual may possess, where he may possess them, or how he may carry them. This justification might do for arms what it has done for speech, which is to say, provide a basis for an extraordinary expansion of its scope..$^{\circ 6}$

Finally, we should also consider how framing might support anti-tyranny justifications. Both of the framing devices considered in this Article may help support such justifications, either on the ground that minorities require special protection from despotic governments or that individuals in general must keep and bear the firepower to resist tyranny. $5 \%$ These justifications may also expand the scope of the Second Amendment beyond its seemingly narrower self-defense parameters.

\footnotetext{
503. Steven Shiffrin, The First Amendment and Economic Regulation: Away from a General Theory of the First Amendment, $78 \mathrm{NW}$. U. L. REV. $1212,1252(1984)$ (" $[\mathrm{T}]$ he Court has been unwilling to confine the $[\mathrm{F}]$ irst $[\mathrm{A}]$ mendment to a single value or even to a few values. In recent years, the $[F]$ irst $[A]$ mendment literature has exploded with commentary finding $[\mathrm{F}]$ irst $[\mathrm{A}]$ mendment values involving liberty, self-realization, autonomy, the marketplace of ideas, equality, selfgovernment, checking government, and more.").

5O4. BLOCHER \& MILLER, supra note 34 , at $148-72$.

505. See id. at 159 .

5o6. See generally Timothy Zick, Arming Public Protests, 104 IOWA L. ReV. 223 (2018)

(discussing factors that will likely affect future public exercises of Second Amendment rights).

5o7. BloCIItR \& Millitr, supra note 34, at 164-69 (discussing Second Amendment and antityranny justifications).
} 


\section{CONCLUSION}

How advocates, scholars, politicians and the public frame the Second Amendment affects constitutional discourse and constitutional community. Their vocabulary and narratives also affect how courts and lawmakers interpret and enforce the right to keep and bear arms. The way we talk about and debate constitutional rights is an important part of the dynamic process in which law and politics relate to one another and courts interpret constitutional rights.

Gun rights advocates have successfully developed and deployed Second Amendment "civil rights" and "civil liberties" frames. They have presented the Second Amendment to the public in anti-discrimination, autonomy, and antityranny terms. They have communicated these frames in constitutional terms, using the language of equality and liberty. These framing devices have significantly affected gun policy, constitutional debates regarding gun rights and gun control, and official interpretations of the Second Amendment. Despite the flaws in their more aggressive strains, the civil rights and civil liberties frames will likely continue to exert these influences.

Studying these frames reveals their immense rhetorical and political power. It also reveals the current absence of effective counter-frames by gun control proponents. Advocates of arms restrictions will not succeed by denying the historical connection between race and firearms or resisting the legitimacy of Heller. Ultimately, they will have to develop effective Second Amendment frames of their own and deploy them in constitutional discourse. More balance will not necessarily produce a more functional gun rights discourse, but it would offer the public and policymakers a choice of narratives they do not currently have. 